\title{
ESTUDO COMPARATIVO DA REABSORÇÃO \\ RADICULAR APICAL, DECORRENTE DO TRATAMENTO \\ ORTODÔNTICO, EM PACIENTES TRATADOS COM A \\ TÉCNICA DO ARCO DE CANTO SIMPLIFICADA, DO ARCO \\ RETO E COM A TERAPIA BIOEFICIENTE
}

GRAZIELA DE LUCA CANTO

Dissertação apresentada à Faculdade de Odontologia de

Bauru, da Universidade de São Paulo, como parte dos requisitos para obtenção do título de Mestre em Odontologia, área de Ortodontia.

Orientador: Prof. Dr. Guilherme R. P. Janson

\section{BAURU}

1997 


CANTO, Graziela De Luca
Estudo comparativo da reabsorção radicular apical,
decorrente do tratamento ortodôntico, em pacientes tratados
com a técnica do arco de canto simplificada, do arco reto e
com a terapia bioeficiente/Graziela De Luca Canto.-Bauru,
1997.
$162 p$. mais apêndices : il. ; $30 \mathrm{~cm}$
Dissertação (Mestrado) Faculdade de Odontologia de
Bauru. USp
Bauru. USP

Orientador: Prof. Dr. Guilherme dos R. P. Janson 


\section{GRAZIELA DE LUCA CANTO}

20 de dezembro de 1965

Criciúma-SC

1983-1986

1992

1995-1997

Associações
Nascimento

Curso de Graduação em Odontologia na Universidade Federal de Santa Catarina.

Professora Auxiliar de Ensino do Departamento de Estomatologia da Universidade Federal de Santa Catarina.

Curso de Mestrado em Odontologia, área Ortodontia, na Faculdade de Odontologia de Bauru, Universidade de São Paulo.

Grupo Brasileiro de Professores de Ortodontia e Odontopediatria.

$\mathrm{SBPqO}$ - Sociedade Brasileira de Pesquisa Odontológica. 
Dedicatória

Acredito que tudo o que somos deriva de nossos antepassados. Por este motivo, dedico este trabalho:

Aos meus avós paternos, Mário* e Laura Canto*, de quem herdei o amor pela Odontologia e

Aos meu avós maternos, Jorge* e Gilia De Lucca, exemplos de vida, que muito contribuíram para a formação do meu caráter.

* in memorian 
Minha profunda gratidão:

Ao meu marido, Luiz Tadeu, por ter entendido o meu sonho e ter lutado comigo, lado-a-lado, para alcançá-lo;

Aos meus pais, Murilo e Icelda, que não mediram esforços para a minha formação;

À minha irmã, Adriana, por sua contagiante alegria de viver;

Ao meu irmão, José Roberto e à minha cunhada Cleonisse, pela amizade e pela paciência que tiveram ao me ensinar os primeiros passos na informática;

À Joecí, minha "irmã de coração", para quem todas as palavras de agradecimento seriam poucas;

À minha madrinha, Dalva, de quem herdei o dom de ensinar . 
Minha admiração e reconhecimento:

Ao Professor Doutor Guilherme Pereira dos Reis Janson, que me orientou neste trabalho, por ter me ensinado a superar limites em busca do conhecimento. Certamente nunca esquecerei o rigor do seu senso crítico e a determinação em alcançar seus objetivos. Hoje tenho convicção de que tudo valeu a pena e orgulho-me de ter sido sua orientada. 
Meu agradecimento especial:

Ao Prof. Dr. Décio Rodrigues Martins, por não ter poupado esforços em tentar nos tornar Mestres;

Ao Prof. Dr. José Fernando Castanha Henriques, Coordenador do Curso de Pós-Graduação em Ortodontia, em nível de Mestrado, por sua preocupação com a qualidade da nossa formação;

Aos demais Professores do Departamento de Ortodontia, da FOB, Prof. Dr. Arnaldo Pinzan, Prof. Dr. Marcos Freitas e Prof. Dr. Renato Almeida, pela valiosa contribuição em minha formação profissional;

Ao Prof. Dr. Anthony D. Viazis, por sua disponibilidade, profissionalismo e pelo seu constante incentivo;

Aos Professores da Disciplina de Oclusão, da Universidade Federal de Santa Catarina, Prof. Dr. Antônio Carlos Cardoso, Professor Berthodo Werner Salles e Professor Rui Tavares, pelo apoio, amizade e esforço conjunto no trabalho adicional provocado pelo meu afastamento. 


\section{Agradecimentos:}

À Profa. Dra. Maria José de Carvalho Rocha, ex-chefe do Departamento de Estomatologia da Universidade Federal de Santa Catarina, per ter me proporcionado um bom exemplo de dedicação à carreira docente;

Ao Prof. Dr. José Alberto de Souza Freitas, Superintendente do Hospital de Lesões Lábio-Palatais, e sua família, especialmente à sua filha Patrícia, pelas constantes manifestações de carinho e amizade;

Aos Professores Omar Gabriel da Silva Filho e Terumi Okada, ortodontistas do Hospital de Lesões Lábio-Palatais, por me ensinarem a amar a Ortodontia;

Ao Prof. Dr. Luiz Fernando Pegoraro, pelas palavras de apoio e otimismo, as quais suavizaram os momentos difíceis e deram-me força para seguir adiante;

Ao Prof. Dr. Luiz Narciso Baratieri, Prof. Dr. Mauro Caldeira de Andrade, Prof. Dr. Sylvio Monteiro Júnior e Prof. Dr. Fernando Borba de Araújo, que sempre me apoiaram, por terem confiado no meu trabalho;

Ao Prof. Dr. Arno Locks, Professor da Disciplina de Ortodontia, da Universidade Federal de Santa Catarina, cuja amizade e incentivo a mim dedicados desde a Graduação, reforçaram a minha vontade de crescer profissionalmente;

Aos meus amigos tão especiais, Analúcia e Jorge Alegria, Márcia Yuri e Eduardo Dainesi, Eliete Neves da Silva, Giselli Amin, Karine Pinera, Mylene Saturnino de Brito e Vera Bosco, por terem participado dos bons e dos maus momentos que vivi nesses 3 anos;

À minha querida amiga e colega de Mestrado, Letícia Fabbrizzi Souza e seus pais, Ary e Wilma, que me acolheram e foram a minha família em Bauru; 
Aos demais colegas de Mestrado, Ana Patrícia Leon, Cláudia C. Silva, Galdino Iague Neto, Júlio Vargas, Liliana M. Brangeli, Márcio Almeida, Nicholas Varagoza, Renato Marçari, Ricardo Takahashi e Suzi N. Santos, pela agradável convivência durante o curso;

Aos colegas de Doutorado, Eduardo Dainesi, Ênio Mazziero, Jorge Alegria, Júlio Gurgel, Márcia Yuri Kawauchi e Pedro Paulo Gondim, pela dedicação e esmero durante a elaboração dos casos que fizeram parte da amostra deste trabalho e, principalmente, pela amizade;

Ao CD Luiz Carlos Cabral e aos funcionários da Clínica Santista de Ortodontia, pelo carinho com que me receberam e pelo esforço conjunto no tratamento dos pacientes que constituíram parte da amostra analisada, sem os quais este trabalho não poderia ter sido realizado;

Aos alunos do curso de Mestrado e especialização em Ortodontia da FOB, por terem atendido parte dos pacientes da amostra deste trabalho;

Ao Prof. Dr. Orivaldo Tavano, Chefe do Departamento de Estomatologia da FOB, por ter permitido a utilização da Clínica de Radiologia;

Ao Célio Coelho Portela, funcionário da Clínica de Radiologia da FOB, pela incansável ajuda durante a obtenção das radiografias;

Aos funcionários do Departamento de Ortodontia da FOB, Cristiane Cano, Daniel Selmo, Luis Sérgio Vieira, Tereza Cristina Camaforte, Vera L. Purgato e à Maria J. Formenti, a "Tia Maria", "anjo da guarda" de todos os alunos, pela atenção conferida;

Aos funcionários da Pós-Graduação, em especial à Ana Bocchio, pela presteza e carinho;

Aos funcionários da Biblioteca, pela cordialidade;

A todos aqueles que, de alguma maneira, contribuíram para a realização desta pesquisa. 
Agradecimentos àqueles que participaram diretamente da elaboração deste trabalho

À Letícia Fabrizzi Souza, por ter sido a segunda examinadora;

À Eliete Neves da Silva e Sérgio Kioshi Ishikiriama, pela “escanerização" das imagens;

Ao Antônio Fernando Lima, pela competência com que realizou o tratamento e a impressão das imagens radiográficas;

Ao Professor Sérgio T. de Freitas, pela realização da análise estatística;

Ao Eduardo Dainesi, Márcia Yuri Kawauchi e Eliete Neves da Silva, por sua dedicação na revisão do texto;

À Professora Sylvanira S. Bramante, pela revisão gramatical;

Ao Marcos Thame, pela excelência das cópias realizadas.

\section{Agradecimentos Administrativos}

Ao Prof. Dr. Rodolfo Pinto da Luz, Reitor da Universidade Federal de Santa Catarina;

Ao Prof. Dr. Dagoberto Sottovia Filho, Diretor da Faculdade de Odontologia de Bauru;

Ao Prof. Dr. Luiz Fernando Pegoraro, Coordenador da Pós-Graduação da Faculdade de Odontologia de Bauru;

À CAPES, pela concessão da bolsa de estudo. 


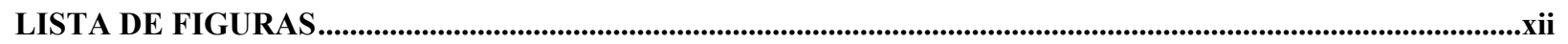

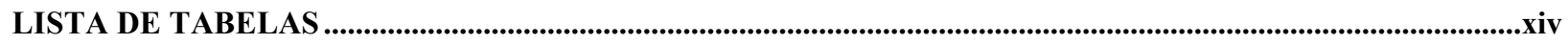

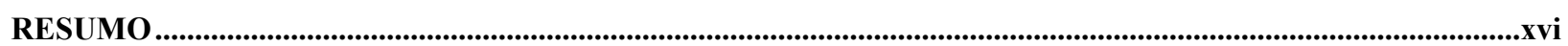

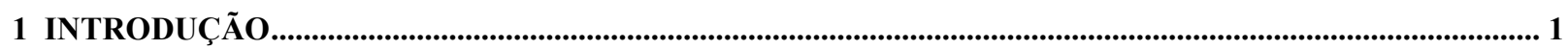

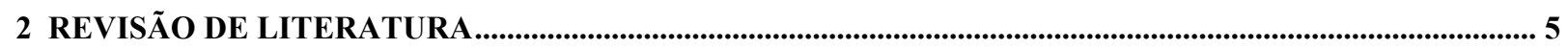

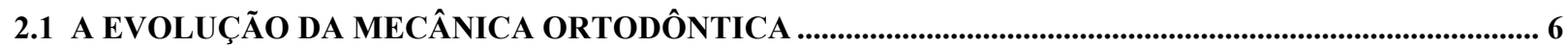

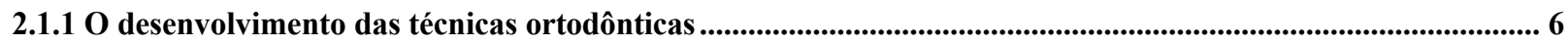

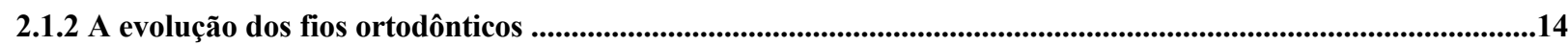

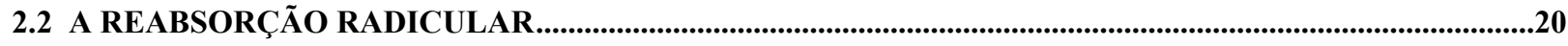

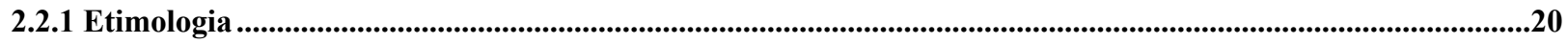

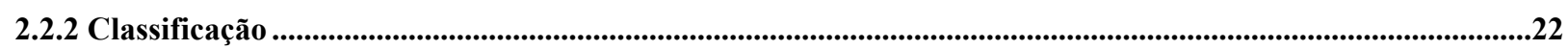

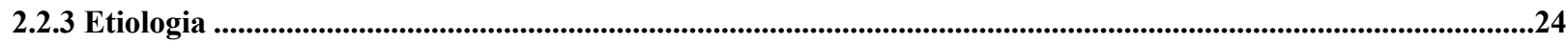

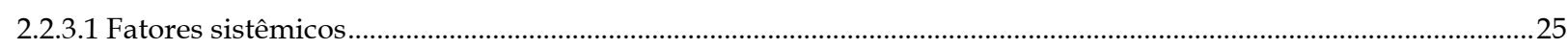

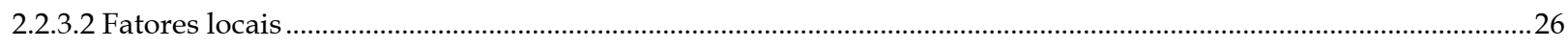

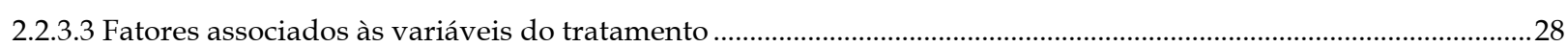

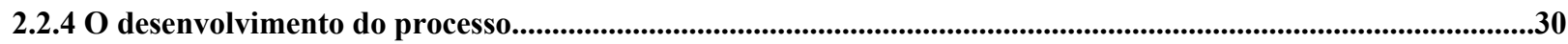

2.2.5 Reabsorção radicular associada à movimentação dentária induzida ..............................................................36

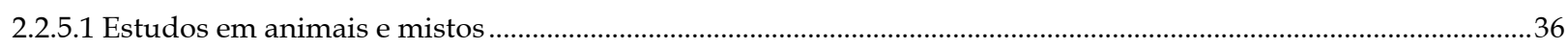

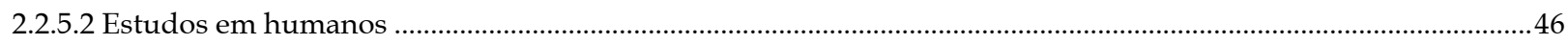

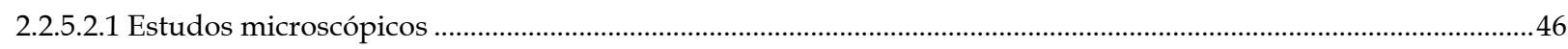

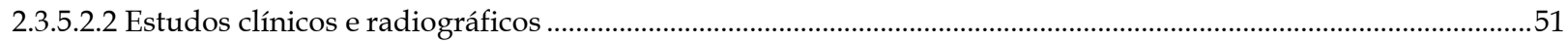

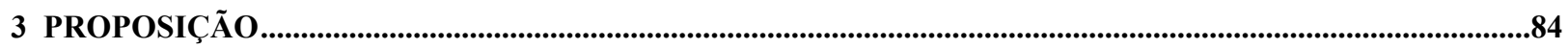

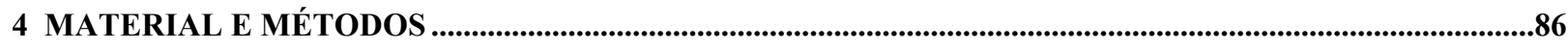

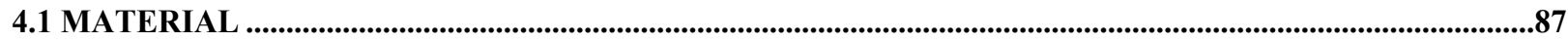

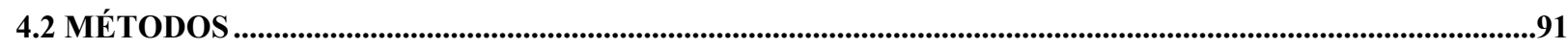

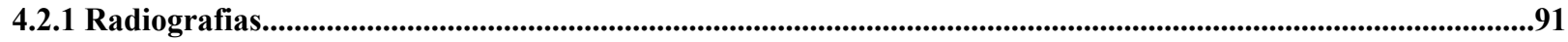




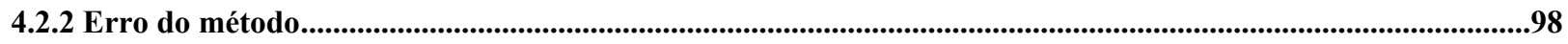

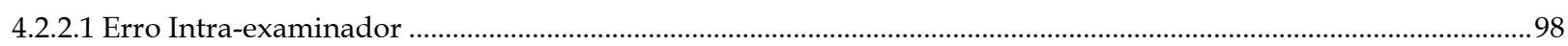

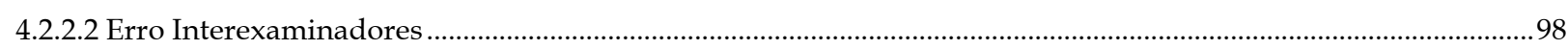

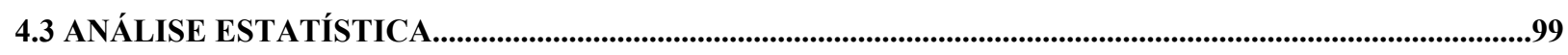

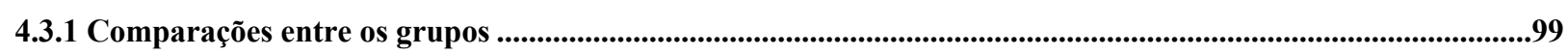

4.3.2 Quantidade de reabsorção radicular decorrente do tratamento ortodôntico .........................................................100

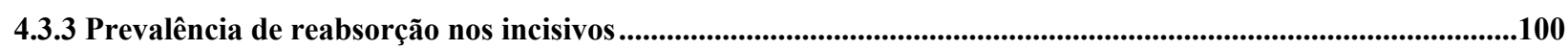

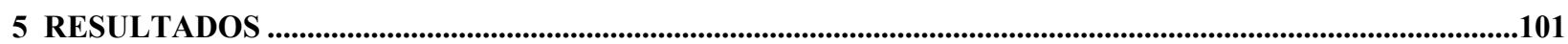

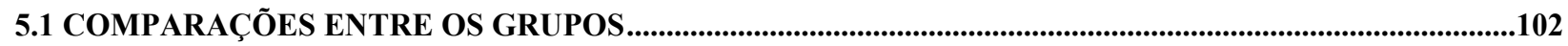

5.2 QUANTIDADE DE REABSORÇÃO RADICULAR DECORRENTE DO TRATAMENTO

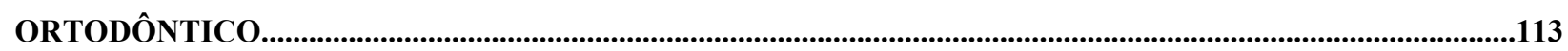

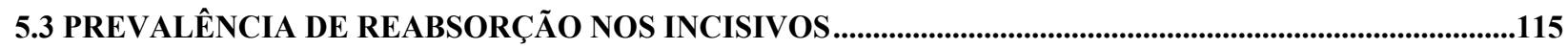

6 DISCUSSÃ

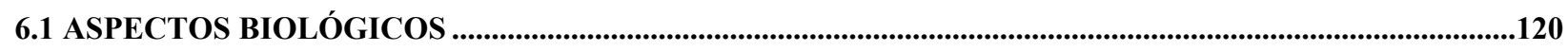

6.2 CONSIDERAÇÕES RELACIONADAS À AMOSTRA E AO MÉTODO...........................................................124

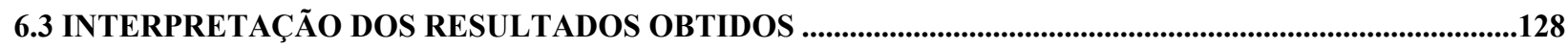

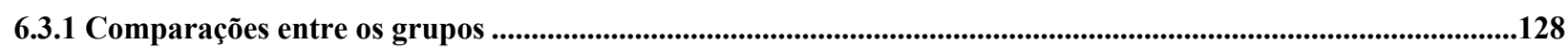

6.3.2 Quantidade de reabsorção radicular decorrente do tratamento ortodôntico .....................................................135

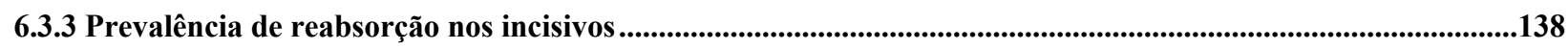

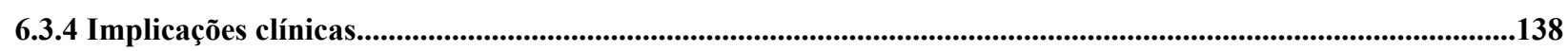

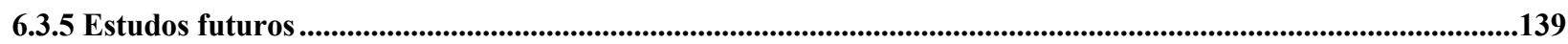

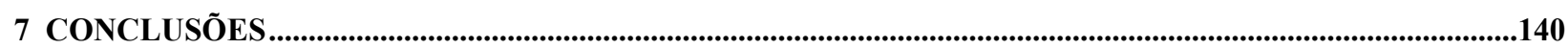

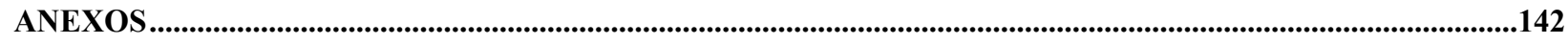

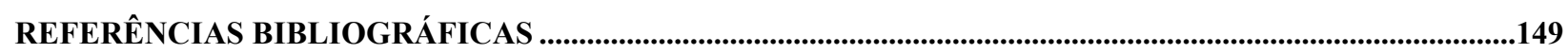

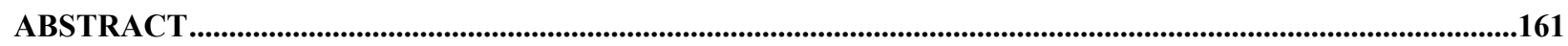

APÊNDICES 
FIGURA 4.2 - $\quad$ Técnica do Arco Reto $\quad 89$

FIGURA 4.3 - $\quad$ Terapia Bioeficiente $\quad 89$

FIGURA 4.4 - Classificação dos graus de reabsorção segundo LEVANDER; MALMGREN76

FIGURA 4.5 - $\quad$ Radiografia periapical de incisivo com grau 0 de reabsorção 94

FIGURA 4.6 - Radiografia periapical de incisivo com grau 1 de reabsorção 94

FIGURA 4.7 - $\quad$ Radiografia periapical de incisivo com grau 2 de reabsorção 95

FIGURA 4.8 - $\quad$ Radiografia periapical de incisivo com grau 3 de reabsorção 95

FIGURA 4.9 - $\quad$ Radiografia periapical de incisivo com grau 4 de reabsorção 96

FIGURA 4.10 - $\quad$ Ficha utilizada para anotação dos graus de reabsorção 97

FIGURA 5.1 - $\quad$ Porcentagem de dentes classificados com os escores $0,1,2,3$ e 4, nos 3 grupos estudados $(n=712)$

FIGURA 5.2 - $\quad$ Comparação da quantidade de reabsorção encontrada individualmente, nos 3 grupos estudados

FIGURA 5.3 - $\quad$ Comparação da quantidade de reabsorção encontrada nos dentes superiores, nos 3 grupos estudados $(n=355)$

FIGURA 5.4 - $\quad$ Comparação da quantidade de reabsorção encontrada nos dentes inferiores, nos 3 grupos estudados $(\mathrm{n}=357)$

FIGURA 5.5 - $\quad$ Comparação da quantidade de reabsorção encontrada entre os pacientes tratados na FOB e os tratados na clínica particular (CP)

FIGURA 5.6 - $\quad$ Comparações da quantidade de reabsorção entre os grupos 1 e 2 e o subgrupo FOB

FIGURA 5.7 - $\quad$ Comparação do tempo de tratamento nos 3 grupos

FIGURA 5.8 - $\quad$ Comparação da quantidade de extrações nos 3 grupos

FIGURA 5.9 - $\quad$ Porcentagem de reabsorção encontrada, em relação ao número de dentes $(\mathrm{n}=712)$

FIGURA 5.10 - $\quad$ Porcentagem de reabsorção encontrada $(1,2$ = reabsorção variando de leve a moderada; 3 = reabsorção acentuada; 4 = reabsorção extrema), em relação ao número de pacientes estudados $(\mathrm{n}=90)$

FIGURA 5.11 - $\quad$ Escores médios de reabsorção para cada incisivo, considerando-se os grupos individualmente (ICS = incisivo central superior; ILS = incisivo lateral superior; ICI = incisivo central inferior; ILI = incisivo lateral inferior) 
FIGURA 5.12 - $\quad$ Escores médios de reabsorção para cada incisivo, considerando-se os 3 grupos estudados (ICS = incisivo central superior; ILS = incisivo lateral superior; ICI = incisivo central inferior; ILI = incisivo lateral inferior) 
TABELA 4.1 - Média de idade e número de extrações para os 3 grupos estudados

$\begin{array}{lll}\text { TABELA } 4.2 \text { - } & \text { Erro intra-examinador } & 98\end{array}$

$\begin{array}{lll}\text { TABELA } 4.3-\quad \text { Erro interexaminadores } & 99\end{array}$

$\begin{array}{lll}\text { TABELA } 5.1 \text { - } & \text { Escores obtidos nos grupos 1, } 2 \text { e } 3(\mathrm{n}=712) & 103\end{array}$

TABELA 5.2 - $\quad$ Comparação da quantidade de reabsorção nas 3 técnicas utilizadas (teste de Kruskal-Wallis)

TABELA 5.3 - Comparações individuais entre os grupos 1 e 2, 1 e 3 e 2 e 3 (teste de KruskalWallis)

TABELA 5.4 - Escores encontrados nos dentes superiores, nos 3 grupos estudados $(n=355)$

TABELA 5.5 - Escores encontrados nos dentes inferiores, nos 3 grupos estudados $(n=357)$

TABELA 5.6 - Comparação da quantidade de reabsorção encontrada no grupo 3, entre os pacientes tratados na FOB e na clínica particular (teste de Mann-Whitney)

TABELA 5.7 - Comparação da quantidade de reabsorção nos 3 grupos, utilizando o subgrupo tratado na FOB (teste de Kruskal-Wallis)

TABELA 5.8 - $\quad$ Comparação entre os 3 grupos, em relação ao tempo de tratamento e à quantidade de extrações (Análise da variância - Teste F)

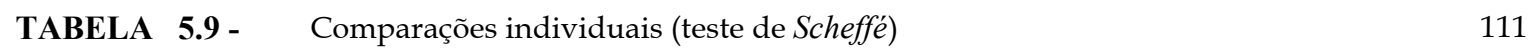

TABELA 5.10 - Quantidade de extrações realizadas, em média, em cada grupo 112

TABELA 5.11 - Porcentagem de pacientes que apresentaram reabsorção leve, moderada, acentuada e extrema

TABELA 5.12 - $\quad$ Escores médios de reabsorção, para cada incisivo, nos grupos 1, 2 e 3

TABELA 6.1 - $\quad$ Métodos radiográficos utilizados por diversos autores, no estudo da reabsorção radicular

TABELA 6.2 - Tempos médios de tratamento, encontrados por alguns autores que estudaram 
TABELA 6.3 - $\quad$ Porcentagem de reabsorção extrema encontrada por alguns autores, em relação ao número de dentes 
A reabsorção radicular apical constitui um efeito indesejável, porém freqüente, do tratamento ortodôntico e por este motivo, várias técnicas e materiais têm sido desenvolvidos visando diminuir esse efeito deletério. Uma das mais recentes técnicas desenvolvidas é a Terapia Bioeficiente, que utiliza materiais ortodônticos contemporâneos. O objetivo principal deste estudo foi comparar a quantidade de reabsorção radicular pós-tratamento, em pacientes tratados com a técnica do Arco de Canto Simplificada (grupo 1), do Arco Reto (grupo 2) e com a Terapia Bioeficiente (grupo 3). Buscou ainda, comparar o tempo de tratamento entre as técnicas, avaliar a quantidade de reabsorção radicular apical decorrente do tratamento ortodôntico e a prevalência da reabsorção nos incisivos superiores e inferiores. Deste modo, foram obtidas radiografias periapicais, pela técnica do paralelismo, dos incisivos superiores e inferiores de 90 pacientes, divididos em 3 grupos, os quais apresentavam uma média de idade ao início do tratamento de 13,92, 14,18 e 14,29 anos nos grupos 1, 2 e 3 , respectivamente. A reabsorção foi classificada por escores, por 2 examinadores, de acordo com o método proposto por LEVANDER; MALMGREN76. A calibração intra e interexaminadores foi considerada excelente pelo coeficiente de concordância de Kendall. Os resultados do teste de Kruskal-Wallis demonstraram que o grupo 3 (Terapia Bioeficiente) apresentou menos reabsorção que os demais. O teste de Scheffé revelou que o tempo de tratamento foi maior para o grupo 1 (Arco de Canto Simplificada) do que para os demais. Considerando toda a amostra, não se encontrou reabsorção radicular em 2,25\% dos dentes analisados. Foi observada reabsorção leve em 42,56\% dos dentes, reabsorção moderada em 53,37\%, reabsorção acentuada em $1,40 \%$ e em somente $0,42 \%$ dos dentes, a reabsorção foi classificada como extrema. A prevalência de reabsorção para cada incisivo indicou maior reabsorção para os incisivos centrais superiores, seguidos dos incisivos laterais superiores, incisivos centrais inferiores e, por último, os incisivos laterais inferiores. 


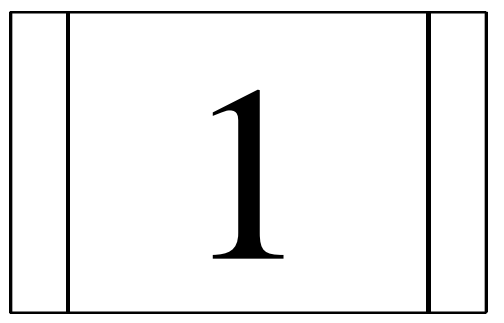

INTRODUÇÃO 


\section{INTRODUÇÃO}

A reabsorção das raízes dos dentes permanentes ainda constitui um enigma para os ortodontistas. Vários fatores têm sido relacionados a esse processo indesejável e patológico, destacando se, entre eles, os processos inflamatórios periapicais, as compressões císticas e as de dentes impactados ${ }^{101,110}$, as deficiências metabólicas ${ }^{44}$, os distúrbios hormonais $^{78} \mathrm{e}$ as forças impostas pela movimentação ortodôntica ${ }^{42,67,78,92,101,109,126,137}$. A possível relação entre a Ortodontia e a reabsorção radicular apical de dentes permanentes foi primeiramente discutida por OTOLLENGUI ${ }^{95}$, em 1914 e comprovada, radiograficamente, treze anos mais tarde, por KETCHAM ${ }^{67}$.

Desde então, a movimentação ortodôntica tem sido relatada como a principal causadora desse problema.

Mesmo à luz das mais recentes descobertas, os fatores indutores específicos desse efeito iatrogênico ainda não foram elucidados, provavelmente porque uma ampla gama de variáveis, como as características teciduais, a adaptação funcional e as reações individuais desempenham um valor preponderante na determinação da presença e do grau da reabsorção. Além disso, deve ser considerada a individualidade profissional, na aplicação de qualquer técnica ${ }^{123}$.

$\mathrm{Na}$ incapacidade de eliminar os fatores inerentes ao paciente, os ortodontistas buscam, incansavelmente, novos materiais e novas técnicas que minimizem esse efeito indesejável do tratamento.

Nos primórdios da Ortodontia, materiais como o bambu, cunhas, placas de madeira e o ouro, foram utilizados na confecção dos aparelhos ortodônticos ${ }^{25}$. 
No século XIX, quando poucos clínicos dedicavam $\sim$ se exclusivamente à Ortodontia, os materiais utilizados constituíam se dos mesmos materiais empregados na construção de próteses totais e parciais, ou seja, o ouro e a prata ${ }^{25}$.

Em 1887, ANGLE ${ }^{13}$ introduziu o uso da liga de níquel prata, cujas qualidades eram muito superiores aos materiais utilizados até então. Seu primeiro aparelho, o arco E, foi desenvolvido no final do século XIX e mais tarde substituído pelo pino tubo ${ }^{106}$. Em 1916, ANGLE ${ }^{13}$, desenvolveu o "arco cinta", posteriormente suplantado pela criação do Arco de Canto, em 1928. Este último caracterizava se por apresentar um bráquete com ranhura horizontal, o qual recebia um arco de formato retangular, introduzido "de canto", com sua maior dimensão paralela ao plano horizontal. Esse princípio deu origem ao nome da técnica apresentada, utilizada até os dias atuais.

A necessidade de se obter ligas com melhores qualidades e menor custo incentivou a busca de novos materiais ${ }^{13}$. Por volta de 1929 , os fios de aço inoxidável começaram a ser empregados na Ortodontia e foram considerados soberanos por um longo período de tempo ${ }^{70}$.

Em 1963, surgiram as primeiras ligas de níquel titânio ${ }^{5,90}$, introduzidas na Ortodontia por ANDREASEN; HILLEMAN ${ }^{5}$, somente em 1971.

Quatorze anos mais tarde, os novos fios de níquel titânio superelásticos, conhecidos por liberar forças suaves e contínuas por longos períodos de tempo, foram desenvolvidos, primeiramente na China ${ }^{34}$ e no Japão ${ }^{90}$.

Paralelamente à evolução dos fios, os bráquetes foram sendo aprimorados, aproveitando melhor as qualidades desses fios ${ }^{60}$.

ANDREWS ${ }^{11}$, em 1976, percebendo que os ortodontistas executavam dobras semelhantes nos arcos de quase todos os pacientes, 
questionou a razão de se realizar idêntico procedimento, repetidamente, para a obtenção dos mesmos resultados. Deste modo, desenvolveu a técnica do Arco Reto, que caracteriza se por ter incorporado aos bráquetes as dobras antes realizadas manualmente.

A evolução dos materiais empregados na confecção dos fios ortodônticos visou melhorar o tratamento, tornando o mais confortável ao paciente e permitindo que o ortodontista atue dentro de limites biologicamente definidos. As novas ligas metálicas, utilizadas sabiamente, podem diminuir os riscos inerentes ao tratamento ortodôntico ${ }^{121}$.

Em 1995, VIAZIS135,136, desenvolveu bráquetes triangulares, cujas características visavam aproveitar $o$ melhor das propriedades dos fios da nova geração de níquel titânio, promovendo forças suaves, tornando a intervenção mais biológica e, como conseqüência, diminuindo o desconforto do paciente e o risco de reabsorção radicular. Esses bráquetes, associados aos fios Bioforce Ionguard*, constituíram a técnica, denominada pelo autor, de Terapia Bioeficiente.

No entanto, ainda pairam dúvidas em relação ao potencial de reabsorção radicular que pode ser gerado quando se utiliza essa técnica, levando à necessidade de pesquisas que avaliem a diferença na freqüência e na intensidade da reabsorção radicular provocada pela mesma, quando comparada a outras técnicas utilizadas até agora.

* GAC International Inc., NY. 


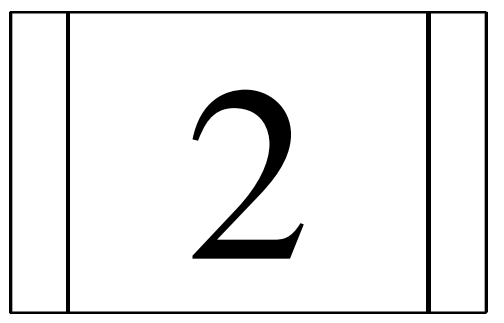

REVISÃO DE LITERATURA 


\section{REVISÃO DE LITERATURA}

Este capitulo revisa a literatura concernente ao assunto deste trabalho, enfocando a evolução da mecânica ortodôntica, a etimologia dos termos "reabsorção" e "absorção", a etiologia e a classificação das reabsorções dentárias, o desenvolvimento do processo de reabsorção e, ainda, apresenta os trabalhos que relacionam a movimentação dentária com a reabsorção radicular.

\subsection{A EVOLUÇÃO DA MECÂNICA ORTODÔNTICA}

\subsubsection{O desenvolvimento das técnicas ortodônticas}

No começo do século, ao mesmo tempo em que publicava a sétima edição do seu livro "Malocclusion of the teeth" (1907), ANGLE $^{13}$ ainda lutava contra os aspectos artesanais da Ortodontia, na confecção e planificação dos aparelhos ortodônticos, visualizando o problema sob dois pontos de vista:

- baseando se na crença dos casos clínicos serem tão particularizados, que não havia possibilidade de sistematização ou estabelecimento de classes de oclusão, conseqüentemente os aparelhos deveriam ser desenvolvidos e construídos com materiais especiais, fazendo se, de cada caso, um trabalho à parte e único;

- conhecendo a diferença das más oclusões em classes bem definidas, haveria a possibilidade de uma certa padronização na conduta este era o ponto de vista predileto de ANGLE ${ }^{13}$. Por meio da sistematização, seria possível alcançar as simplificações, essenciais para o progresso da mecânica ortodôntica, permitindo a familiarização cada vez maior com os aparelhos padronizados e, portanto, o desenvolvimento da habilidade do profissional, fundamental para a 
obtenção de resultados sempre melhores.

O primeiro aparelho de ANGLE ${ }^{13}$, o arco de expansão ou arco E, desenvolvido no final do século XIX, constituía se de bandas nos molares e um arco vestibular, formando um estrutura rígida, na qual os dentes eram amarrados para que pudessem ser expandidos de acordo com a forma ditada pelo aparelho. O arco E inclinava os dentes para uma nova posição, porém, não era capaz de posicioná los individualmente, com precisão. Para suplantar as limitações do aparelho, o autor acrescentou bandas aos outros dentes e usou um tubo vertical em cada um deles, no qual encaixava se um pino, soldado a um arco de menor diâmetro106. Este aparelho era capaz de realizar o movimento dentário pelo reposicionamento dos pinos a cada consulta e foi denominado pino tubo ${ }^{13,106}$.

Em 1916, Angle desenvolveu o primeiro bráquete ortodôntico, para utilizá lo no aparelho "arco cinta"129. Modificando o tubo de cada dente, providenciou um encaixe retangular, posicionado verticalmente atrás do tubo. Um arco cinta de ouro, de 0,030 polegada ${ }^{25}$, era inserido dentro dos encaixes e preso com pinos. Embora o arco cinta pudesse ser curvado quando nessa posição, sua maior desvantagem era o controle relativamente deficiente da posição das raízes. A resiliência do arco cinta não permitia a geração dos momentos necessários para levar as raízes a uma nova posição ${ }^{106}$.

Para superar as deficiências do arco cinta, em 1928, ANGLE ${ }^{13}$ inventou um bráquete com ranhura horizontal, o qual recebia um arco de formato retangular, introduzido "de canto", com sua maior dimensão paralelamente ao plano horizontal. Esse princípio deu origem ao nome da técnica apresentada (técnica do Arco de Canto ou Edgewise), determinando uma evolução na mecanoterapia ortodôntica13,25. Logo após, as dimensões do encaixe foram alteradas para 0,022 X 0,028 polegada e o arco utilizado era de metal precioso, com a mesma espessura. Essas dimensões, obtidas após 
extensas experiências, permitiram um excelente controle das posições da coroa e da raiz, nos 3 planos espaciais. O autor ${ }^{13}$ acreditava que o melhor equilíbrio, a melhor harmonia e as melhores proporções só seriam obtidos se todos os dentes estivessem presentes e bem posicionados na cavidade bucal ${ }^{16}$. No seu conceito de tratamento, deslizar os dentes ao longo de arcos para fechar os espaços de extração não era necessário, porque ele não realizava extrações com finalidade ortodôntica. O movimento de torque, ao contrário, era importante e o maior objetivo do aparelho era o torque eficiente ${ }^{105}$. Quando os arcos de aço inoxidável substituíram os de ouro, os cálculos de ANGLE ${ }^{13}$ perderam a validade, pois o fio de aço, da mesma espessura do ouro, era muito mais duro. A alternativa foi redesenhar o aparelho, otimizando o tamanho do encaixe do bráquete para o aço ${ }^{105}$. O encaixe foi então reduzido para 0,018 polegada, porém os fios, com a mesma dimensão, ainda produziam forças ligeiramente maiores do que no sistema original. Por outro lado, utilizando arcos menos espessos, podia se reduzir a fricção, permitindo o deslizamento do dente ao longo do arco ${ }^{105}$.

Devido à insistência de Angle em expandir os arcos em vez de realizar extrações, torna se irônico o fato do aparelho do Arco de Canto finalmente fornecer o controle da posição das raízes, necessário para o sucesso da terapia com extrações ${ }^{106}$.

Tweed foi o líder nos Estados Unidos, na adaptação do aparelho edgewise para o tratamento com extrações ${ }^{16,43}$. Foi o homem de maior importância na Ortodontia, desde Angle ${ }^{43}$. Em 1941, ele revolucionou a Ortodontia, fazendo dos dentes anteriores o principal foco de diagnóstico e advogando a realização de extrações, quando necessárias, para alcançar os objetivos do tratamento ${ }^{43}$. Tweed retratou 100 casos completamente, inicialmente tratados sem extrações, porque estava convencido de que obteria melhores resultados com a extração de 4 pré molares e a retração dos dentes anteriores $^{43}$. O autor promovia a movimentação dentária de corpo e usava a 
subdivisão do arco dentário como solução para o controle da ancoragem, primeiro deslizando o canino distalmente, ao longo do arco, para depois retrair os incisivos ${ }^{106}$.

Begg aprendeu a utilizar o arco cinta na escola de Angle, antes de retornar à Austrália, no final da década de 20106. Trabalhando independentemente, em Adelaide, $\mathrm{BEGG}^{23}$ também constatou que as extrações de dentes eram freqüentemente necessárias e, em 1961, começou a adaptar o aparelho arco cinta para ser utilizado com maior controle da posição radicular. Foram 3 as adaptações instituídas por BEGG ${ }^{23}$ : substituiu o arco cinta de metal precioso por um arco de aço inoxidável de alta resistência, com espessura de 0,016 polegada, manteve o bráquete original do arco cinta, porém colocou o de cabeça para baixo, de modo que o encaixe do bráquete ficasse apontado para gengival e adicionou molas auxiliares ao aparelho para controlar a posição das raízes. Como resultado, o atrito foi minimizado devido à pequena área de contato entre o fio e o bráquete estreito do $\operatorname{arco~} \sim \operatorname{cinta}{ }^{106}$. $\mathrm{BEGG}^{23}$ afirmava que todos os tipos de movimento poderiam ser realizados com o seu aparelho e que a mecânica de fios leves diminuía o tempo necessário para o tratamento e o tempo de cadeira. Dizia também que a alta resiliência dos arcos promovia movimentos rápidos e os dentes podiam ser movidos a grandes distâncias sem necessidade de reajustes do aparelho. Ressaltava, ainda, que as forças aplicadas eram leves, produzindo menor desconforto clínico e menor perda de estrutura dentária. O aparelho de BEGG23, caracterizado por utilizar apenas fios redondos, ainda é utilizado, embora a sua popularidade tenha diminuído ${ }^{106}$. É um aparelho completo, considerando que permite um bom controle da posição da coroa e das raízes em todos os 3 planos do espaço. A maior dificuldade está na fase final do tratamento, na obtenção de uma posição precisa dos dentes ${ }^{106}$. 
Excetuando se a técnica de BEGG ${ }^{23}$, pode $\sim$ se dizer que os aparelhos fixos contemporâneos são variações dos aparelhos edgewise, desenvolvidos por Angle106.

A mecânica do Arco de Canto tradicional caracteriza $\sim$ se pela troca seqüencial de fios ortodônticos de aço inoxidável de diferentes calibres. A progressiva troca de fios com secção transversal maior visa uma grande variação da força e um maior controle sobre os dentes, pela diminuição da folga entre os bráquetes e o fio. Os fios de pequeno calibre, com ou sem alças e fios trançados podem ser utilizados a fim de se obter uma maior elasticidade do aparelho. Com esses artifícios, modifica se a configuração do aparelho, mantendo se o material do qual o fio é constituído. Esse procedimento exige do ortodontista um senso clínico muito grande, pois pequenas variações nos fios, sejam pela forma ou pela evolução do tratamento durante as trocas dos arcos, proporcionam uma enorme variação da força aplicada aos dentes e estruturas de suporte. Além disso, como a maioria das técnicas do Arco de Canto utiliza arco contínuo, o alinhamento dos dentes é realizado de forma indiscriminada, ou seja, o incisivo lateral recebe a mesma força que o canino, por exemplo ${ }^{121}$.

Até 1965, todos os aparelhos disponíveis utilizavam bandas cimentadas aos dentes. Em 1966, a técnica de colagem direta foi desenvolvida e utilizada, pela primeira vez, no Orthodontic Department of the Eastman Dental Center, na Universidade de Rochester. O experimento utilizou bráquetes de metal, com ranhura única $0,018 \mathrm{X}$ 0,025 polegada e com o mesmo sistema adesivo utilizado anteriormente para o selamento de fóssulas e fissuras. Somente os incisivos superiores e os caninos, em alguns casos, foram colados e após um período de avaliação que variou de 8 a 18 meses, apenas uma pequena percentagem de bráquetes soltou $\mathrm{Se}^{40}$.

Insatisfeito com as metas do tratamento, indicadas para cada paciente e baseando se na premissa de que os melhores produtos da 
natureza devem ser copiados, ANDREWS ${ }^{10}$, em 1972, analisou 120 modelos de jovens não tratados e sem necessidade detratamento. Os dentes apresentavam se alinhados, esteticamente agradáveis, sem imperfeições aparentes e com a oclusão correta. A relação e a posição das coroas dentárias foram submetidas a um estudo detalhado. Seis características significantes ocorreram com bastante freqüência, tendo sido denominadas "As seis chaves de oclusão normal": a relação molar, a angulação da coroa, a inclinação da coroa (torque vestibulolingual), a ausência de rotações, a presença de contatos oclusais definidos e a planificação da curva de Spee. Estas características passaram a constituir os objetivos do tratamento em mais de $90 \%$ dos pacientes atendidos pelos ortodontistas americanos. A identidade de objetivos, para a maioria dos pacientes, instigou ANDREWS ${ }^{10}$ a desenvolver um novo aparelho, mais eficiente, economizando tempo na obtenção dos resultados desejáveis do tratamento.

A introdução do tratamento no aparelho já havia sido relatada por HOLDAWAY59, em 1952, angulando os bráquetes nas bandas, e por JARABAK; FIZZELL ${ }^{62}$, em 1963, recomendando o torque e a angulação dos bráquetes. Por volta de 1960, já existiam bandas para os diferentes dentes, porém, os bráquetes da técnica do Arco de Canto não possuíam torque e os bráquetes com torque disponíveis apresentavam apenas angulações de 5 em 5 graus. Não havia um consenso entre os profissionais sobre a quantidade ideal de angulação. Os bráquetes não apresentavam ranhuras anguladas, a espessura entre a base do bráquete e a ranhura era constante, não satisfazendo às exigências do "in out" e, além disso, não possuíam a curvatura vertical, nem o torque pré programado na base. Por tais motivos, ANDREWS ${ }^{11,12}$, em 1976, decidiu desenvolver um aparelho inovador que incorporasse todas essas necessidades do tratamento. Objetivava programar antecipadamente as seis chaves da oclusão, deixando os detalhes da finalização a cargo do ortodontista. A técnica desenvolvida, denominada de técnica do Arco Reto, posiciona as 
ranhuras dos bráquetes em uma linha reta na finalização do tratamento ativo, de modo que um arco retangular possa ser introduzido sem dobras ou torções. Preconiza um ponto de localização específico e exato para a colocação do bráquete. Relaciona algumas características não encontradas, em conjunto, nos aparelhos disponíveis comercialmente, até então. Dentre as inovações estão o torque na base do bráquete, a base contornada no sentido horizontal e vertical, a inclinação e o "in out" e o "off $\sim \operatorname{set} "$ molar, introduzidos no aparelho. Além disso, o desenho do bráquete apresenta outras inovações: as aletas não são simétricas no sentido horizontal, pois nos bráquetes dos dentes posteriores, as aletas da região gengival são projetadas para fora, permitindo uma amarração mais fácil e eliminando o trauma gengival; as aletas no sentido vertical fornecem um guia para o posicionamento do bráquete na coroa, apresentando se paralelas ao longo eixo da coroa clínica. Uma outra característica inovadora consiste na identificação dos bráquetes para cada tipo dentário. No entanto, de todos os fatores citados, as bases contornadas e o torque nela introduzido, constituem as características mais importantes, as quais refletem o principal objetivo da técnica.

Quatro anos mais tarde, em 1980, HANSON51 apresentou o desenho de um novo aparelho edgewise, desenvolvido para facilitar as trocas de arcos e permitir a aplicação de forças para uma correção mais precisa. O nome da técnica, SPEED", foi derivado dos termos "Spring loaded, Precision, Edgewise, Energy e Delivery", características que descrevem o aparelho. Seus principais componentes são o bráquete com 4 ranhuras, um sulco triangular raso, bordas soldadas, a "mola trava" e a ausência de aletas gengivais. Após analisar 600 casos tratados com essa técnica, por um período de 26 meses, HANSON ${ }^{51}$ afirmou que o aparelho SPEED pode diminuir o tempo gasto com a troca do arco em até 5 minutos, por não necessitar de ligaduras; permite um alto grau de precisão no controle tridimensional do

\footnotetext{
* Strite Industries Limited, Cambridge.
} 
dente, característica ideal em mecânicas de deslizamento e apresenta a capacidade de estocar quantidades de energia relativamente grandes, liberando as gradativamente.

Em 1995, VIAZIS 135,136 desenvolveu bráquetes inovadores, que apresentam um desenho triangular, permitindo perfeita movimentação dentária pelo aumento do controle da angulação e da rotação. Além disso, mostram outras características desejáveis: adaptam se ao contorno da margem gengival da coroa, possibilitando um posicionamento coronário mais para cervical; apresentam extrema facilidade para o seu posicionamento; permitem fricção mínima, promovendo menor atrito; possuem extensões laterais para o controle da angulação; exibem configuração alongada e estreita; ranhura vertical que possibilita a utilização eficaz das novas molas de níquel titânio e, ainda, torque anterior acentuado, neutralizando o efeito de inclinação, durante a mecanoterapia ativa, especialmente na fase de retração. Estes, associados aos fios superelásticos retangulares ou quadrados, constituem o aparelho utilizado na técnica desenvolvida por VIAZIS ${ }^{135,136}$ e denominada Terapia Bioeficiente. O objetivo é reduzir o tempo da fase inicial do tratamento, proporcionando maior tempo para a finalização e individualização dos casos, produzindo uma ação mais biológica, com menor desconforto para o paciente. Nesta técnica, diferentemente da técnica do Arco de Canto Simplificada, o tratamento é dividido em duas etapas: aborda as 3 fases iniciais da terapia ortodôntica (alinhamento, nivelamento e fechamento de espaços) como primeira etapa do tratamento e a finalização, como a segunda. Esta diferença propicia ao clínico despender o mesmo tempo na finalização que o empregado na primeira etapa. Na maioria dos casos, utiliza se um sistema de 2 arcos: o primeiro, superelástico (Bioforce Ionguard* ) e um arco de finalização de aço inoxidável61,134,135,136.

* GAC International Inc., N Y 


\subsubsection{A evolução dos fios ortodônticos}

Nos primórdios da Ortodontia, materiais como o bambu, cunhas e placas de madeira e o ouro eram utilizados na confecção de aparelhos ortodônticos ${ }^{25}$.

Em 1887, ANGLE13 introduziu o uso da liga de níquel prata, cujas qualidades eram muito superiores às dos materiais utilizados até então. Logo após foram desenvolvidas ligas mais resistentes, constituídas de ouro, platina e cobre 25 .

A necessidade de se obter ligas com melhores qualidades e menor custo levou os ortodontistas a experimentarem diferentes ligas. Por volta de 1929, os fios de aço inoxidável começaram a ser empregados na Ortodontia e foram considerados soberanos por um longo período de tempo. A introdução das ligas de aço inoxidável fez com que as ligas de metais preciosos fossem descartadas, principalmente em função de seu alto custo ${ }^{105}$. As ligas de aço inoxidável, formadas basicamente de $18 \%$ de cromo e $8 \%$ de níquel ${ }^{105}$, mantiveram a sua popularidade, provavelmente devido à sua dureza, resiliência, formabilidade e, principalmente, em função do seu baixo custo em relação às de ouro 33 .

Desde a metade do século, praticamente todos os aparelhos ortodônticos eram confeccionados com aço inoxidável ou uma liga de cromo cobalto (Elgiloy*), com propriedades semelhantes ${ }^{105}$. O Elgiloy pode ser fornecido em um estado mais macio e, conseqüentemente, com maior formabilidade, para ser, então, endurecido por tratamento térmico. Após esse tipo de tratamento, o fio, bastante maleável, torna se equivalente ao aço inoxidável convencional105,116. A liga é composta de $40 \%$ de cobalto, $20 \%$ de cromo, $15 \%$ de níquel, $7 \%$ de molibdênio e 16\% de ferro. Como vantagens,

\footnotetext{
"Rocky Moutain Orthodontics, Denver, Colorado.
} 
pode se citar, ainda, o fato dela também permitir a soldagem e apresentar excelente resistência à corrosão ${ }^{33}$.

Em 1963, surgiu a primeira liga de níquel titânio, desenvolvida no Laboratório de Artilharia Naval, em Silver Spring (Maryland). Foi denominada de nitinol, em função de sua composição (Níquel e Titânio) e do nome do laboratório na qual foi desenvolvida (Naval Ordnance Laboratory) 5,90 .

Somente em 1971, as ligas de níquel titânio foram introduzidas na Ortodontia, por ANDREASEN; HILLEMAN 5 , sendo comercializadas com o nome de Nitinol* Estas ligas apresentam 2 propriedades notáveis: excelente flexibilidade e memória de forma ${ }^{90}$. A memória de forma refere se à capacidade do material "lembrar se" da sua forma original, após estar praticamente deformado na sua fase martensítica ${ }^{105}$. Sua característica clínica mais significante, quando comparado a um fio de aço inoxidável, consiste na sua resistência em receber dobras. Ele pode ser flexionado sem perder a capacidade de retornar à sua forma prévia. Esta característica, no entanto, pode dificultar a incorporação de dobras e torques, quando necessários. Apresenta como principal e talvez única desvantagem o fato de não permitir a soldagem.

A partir do Nitinol, diversas ligas foram desenvolvidas, variando os seus componentes e a porcentagem dos mesmos ${ }^{5}$. Nos últimos anos, o chamado nitinol elástico, sem cobalto, mostrou se útil na prática clínica em função das suas características de resistência à corrosão, elasticidade e flexibilidade, gerando forças mais suaves e contínuas e propiciando maior movimentação dentária. O nitinol termoativado foi assim denominado em função da sua propriedade de memória de forma, que consiste na capacidade de retornar ao formato inicial, uma vez deformado, no momento em que atinge a sua temperatura de transição, que pode ser ajustada 
alterando se a quantidade de níquel e cobalto ou pelo tratamento térmico. A propriedade de memória de forma permite que o fio tenha uma deformação plástica em uma temperatura abaixo da de transição e assim permaneça até que a temperatura de transição seja atingida, quando inicia o seu retorno ao formato inicial. Com finalidade ortodôntica, a liga ajusta a temperatura de transição para um valor próximo ao da cavidade bucal, permitindo que parte da propriedade de memória de forma do fio seja utilizada para movimentar os dentes ${ }^{6}$.

Além das diferentes ligas desenvolvidas para a confecção dos fios ortodônticos, várias novas configurações foram surgindo. Além do fio redondo, quadrado e retangular, há os fios multitrançados de variados tamanhos, forma e número. Estes, apresentados na literatura por STEPHENS; HOUSTON; WATERS ${ }^{127}$, em 1971, exibem alta elasticidade e baixa rigidez, quando comparados aos fios de aço inoxidável convencionais ${ }^{116}$. Torna se imperioso que as características dos diversos fios sejam conhecidas para serem aplicadas adequadamente em cada situação ${ }^{71}$.

Em 1980, BURSTONE; GOLDBERG ${ }^{33}$ apresentaram uma nova liga de titânio, a beta titânio. Disponível comercialmente com o nome de TMA $^{*}$, oferece uma combinação altamente desejável de resistência e resiliência, bem como uma formabilidade razoavelmente boa. As ligas de beta titânio são compostas de 79\% de titânio, 11\% de molibdênio, 6\% de zircônio e $4 \%$ de um metal proveniente do aquecimento a $885^{\circ} \mathrm{C}$ de titânio puro, cujo arranjo cristalográfico é denominado fase beta. Apresentam um equilíbrio de deflexão máxima e formabilidade com pequena dureza, expressando inúmeras propriedades clínicas. Isto faz do fio uma excelente escolha para a confecção de molas auxiliares e de arcos intermediários e de finalização, especialmente os arcos retangulares, nos estágios finais do tratamento, na técnica do Arco de

\footnotetext{
*Unitek Corporation, Monrovia, Califórnia.

* Ormco Corporation, Glendora, Califórnia.
} 
Canto ${ }^{33}$. Durante a retração do segmento anterior com mola "T" confeccionada de TMA e pré fabricada em casos com extração, por exemplo, diminui a necessidade de ancoragem extrabucal, pois estas molas trabalham dentro de um limite ótimo de força para a retração anterior, porém, baixo para a protração do segmento posterior, como ocorre na maioria dos casos em que molas de aço inoxidável ou elásticos são utilizados ${ }^{121}$.

Ainda na década de 80, surgiram os novos fios de níquel titânio com estrutura austenítica ativa, denominados de A NiTi ${ }^{105}$, desenvolvidos em Beijing, na China, pela equipe do Dr. Tien Hua Cheng, no General Research Institute for Non Ferrous Metals ${ }^{34}$ e no Japão, pela empresa Furukawa Eletric ${ }^{90}$, quase que simultaneamente. O NiTi Chinês foi introduzido na literatura por BURSTONE; QIN; MORTON ${ }^{34}$, em 1985 e no ano seguinte, MIURA et al. ${ }^{90}$ apresentaram o NiTi japonês e discorreram sobre suas impressionantes qualidades. Esses fios apresentam uma propriedade notável, a superelasticidade, tornando os capazes de gerar um movimento dentário mais fisiológico, proporcionando maior conforto ao paciente ${ }^{90}$. A superelasticidade da liga permite que a quantidade de pressão permaneça até certo ponto constante com a deformação do fio. Ao mesmo tempo, com a diminuição da deformação do fio, a quantidade de tensão permanece constante ${ }^{93}$. Isto significa que um arco exerceria aproximadamente a mesma força se fosse defletido numa distância relativamente pequena ou grande, o que é uma característica única e extremamente desejável. As propriedades do A NiTi fizeram dele, rapidamente, o material preferido para as intervenções ortodônticas, nas quais uma grande faixa de ativação, com força relativamente constante, torna se necessária ${ }^{105}$. As ligas superelásticas apresentam aproximadamente $52 \%$ de níquel, $45 \%$ de titânio e $3 \%$ de cobalto ${ }^{5}$. Esta composição permite duas formas cristalográficas: em altas temperaturas, os cristais moleculares dispõem se em uma forma cúbica, chamada forma austenítica, que é estável e pelo resfriamento da liga, os cristais tomam uma 
forma hexagonal, levando a liga metálica à chamada fase martensítica. As moléculas dispõem se em forma de treliça e mudam o arranjo cristalográfico, dependendo da temperatura em que se encontra a liga. A temperatura de transição entre uma e outra fase é controlada pela adição de cobalto e pelo tratamento térmico durante a fabricação da liga. Transição esta que pode ser induzida também pela aplicação de uma força ${ }^{102}$.

Durante a movimentação ortodôntica, é particularmente importante que as forças não decresçam rapidamente, decaindo em função da perda de elasticidade do material, ou devido à pequena quantidade de força aplicada. O comportamento dos materiais elásticos, bem como a resposta dos dentes às forças, devem ser considerados no desenho do aparelho ortodôntico, por meio do qual a mecanoterapia será realizada ${ }^{105}$.

A evolução dos fios ortodônticos continuou com o passar dos anos ${ }^{60}$. A série retangular de fios superelásticos termoativados, denominada NeoSentalloy*, disponível comercialmente nas variações de força suave, média e intensa, podendo atingir 100, 200 e 300 gramas, determinou a próxima etapa dessa evolução. Esse tipo de liga de níquel titânio apresenta o efeito de memória de forma termicamente induzida, ou seja, o fio pode ser inserido na cavidade bucal, retornando à sua forma original por influência da temperatura bucal. A termoelasticidade é a propriedade da liga em que a fase de transformação martensítica para austenítica ocorre quando a temperatura diminui $^{70}$. Posteriormente, os fios retangulares e quadrados Bioforce ${ }^{* *}$ foram aperfeiçoados, apresentando uma força de 80 gramas na região anterior e de 320 gramas na região posterior. Recentemente, foi introduzido na literatura o novo Bioforce Ionguard** O Ionguard consiste de uma camada de cobertura de aproximadamente 3 micra de nitrogênio, sobre o fio de níquel titânio,

\footnotetext{
* TOMY International Inc., Japan.

** GAC International Inc., NY.
} 
obtida pelo bombardeamento de íons em sua superfície. Estes fios apresentam menor atrito, menor incidência de fratura e menor liberação de níquel na cavidade bucal, devido ao processo de ionização' ${ }^{135,135}$.

Deve se salientar que os fios superelásticos não são utilizados somente para a confecção de arcos de nivelamento, mas também para a fabricação de molas e fios de diferentes diâmetros ${ }^{64}$.

A descoberta das propriedades superelásticas das ligas de NiTi e o seu papel na atividade osteoclástica constituem um marco científico importante na especialidade ortodôntica, estabelecendo um novo padrão biológico de tratamento ${ }^{89}$. Porém, o conhecimento das reações teciduais, frente à movimentação dentária com fios superelásticos, ainda não foi elucidado ${ }^{64}$.

Pode ser antecipado para a década de 90 um progresso adicional dos materiais elásticos na Ortodontia. Os mais recentes materiais dos arcos ortodônticos têm sido uma adaptação dos materiais desenvolvidos na tecnologia aeroespacial. As aeronaves de melhor desempenho nas décadas de 70 e 80, por exemplo, foram construídas basicamente de titânio, porém as da geração atual são construídas com compostos plásticos, existindo motivos para acreditar se que "fios" ortodônticos dessa natureza serão utilizados na prática clínica no futuro. Já foi apresentado para uso clínico um "fio" não metálico, o Optiflex* , constituído de uma estrutura compósita, formada por uma cobertura de fibra ótica de vidro (dióxido de silicone puro), com um adesivo derretido pelo calor e uma capa de nylon. Suas vantagens são as forças leves para o nivelamento e sua excelente estética ${ }^{70,105}$.

* Ormco Corporation, Glendora, Califórnia. 


\subsection{REABSORÇÃO RADICULAR}

\subsubsection{Etimologia}

Sempre houve dúvida sobre qual termo deveria ser utilizado para indicar a perda de substância dura que ocorre na porção apical das raízes dos dentes decíduos ou permanentes. Alguns autores definiam este processo como reabsorção, enquanto outros o chamavam de absorção22.

A palavra reabsorção originou se no latim, do verbo resorbere, no qual re significa "de novo" enquanto sorbere significa "sorver, engolir", formando o sentido de "engolir de novo, remover ou retirar de novo". O termo absorção, também do latim, é originário do verbo absorbere, no qual ab indica a não finalização do processo e sorbere significa sorver. Constitui um processo físico utilizado para designar a transferência de elementos nutritivos do trato intestinal para os sistemas sangüíneo e linfático para formar tecidos ${ }^{22}$. As raízes dos dentes permanentes são reabsorvidas por um processo similar e análogo ao que é observado nas raízes dos dentes decíduos, antes da sua esfoliação, sendo a primeira situação um processo patológico e a segunda, fisiológico 22 .

BECKS; MARSHALL ${ }^{22}$, em 1932, para dirimir esta dúvida, recorreram à literatura disponível, visando uniformizar o termo. Os termos utilizados até o momento, absorção e reabsorção, ganhavam conceitos distintos no relatório anual do Comitê de Nomenclatura da American Dental Association (ADA). Segundo o Comitê, absorção significava a retirada, pelos tecidos, de fluidos originários fora do corpo, diferenciando se de reabsorção, a qual constituía a retirada de produtos ou tecidos originários no corpo. Os autores estabeleceram a padronização do termo para reabsorção, independentemente dele ser utilizado para o dente permanente, decíduo, ou, ainda, para o osso. 
Apesar dessa dúvida já ter sido esclarecida, em 1932, por BECKS; MARSHALL ${ }^{22}$, até hoje os conceitos publicados nos dicionários não são esclarecedores.

PEREIRA $^{99}$, em 1956, em seu Dicionário de Sinônimos Odontológicos, definiu absorção como o fenômeno da atração e condensação de um fluido elástico, ou de um líquido, por um corpo sólido ou líquido. Constitui um dos atos da nutrição, no qual o sangue recebe, do exterior, oxigênio e materiais alimentares tornados assimiláveis pela digestão e fornece aos tecidos oxigênio, matérias solúveis e água. Reabsorção foi conceituada como a absorção de um líquido normal ou patológico, derramado em uma das cavidades do organismo. A reabsorção radicular é especialmente referenciada como sendo a absorção da raiz dos dentes decíduos pelos elementos normais (odontoclastos), para dar lugar ao permanente, o que vem a ser o mesmo que rizólise ou rizoclasia. Esse conceito também foi defendido por SCARTEZZINI ${ }^{119}$, oito anos após.

Em 1964, AVELLANAL ${ }^{17}$ citou a absorção como a propriedade dos tecidos orgânicos incorporarem substâncias alimentícias ou medicamentosas. A pele e as mucosas são capazes de absorver algumas dessas substâncias. A reabsorção foi referenciada como a absorção de líquidos anormais do organismo, destruição fisiológica do osso alveolar após a extração dos dentes, ou, ainda, destruição das raízes dos dentes decíduos.

SIMAS ${ }^{124}$, em 1989, afirmou que a absorção é a passagem ou penetração de um medicamento do meio externo para o interno (sangue). A reabsorção constitui um processo de dissolução de sais orgânicos do osso e da matriz orgânica e a transferência dos produtos dissolvidos para os fluidos do corpo.

Recentemente, BLAKE; WOODSIDE; PHAROAH ${ }^{24}$ definiram a reabsorção radicular como um processo fisiológico ou patológico que resulta na perda de cemento e dentina. 
Apesar da diversidade dos conceitos publicados, em Ortodontia, comumente, a expressão utilizada para definir a perda de substância dura na raiz dos dentes permanentes é reabsorção radicular.

$\mathrm{Na}$ realidade, independentemente da natureza do conceito utilizado, constitui se de suma importância o conhecimento da etiologia e do desenvolvimento do processo de reabsorção.

\subsubsection{Classificação}

As reabsorções podem ser classificadas de diversas maneiras, porém, a maioria dos autores classifica as reabsorções sem utilizar um critério específico, dificultando a compreensão* .

FEIGLIN ${ }^{45}$, em 1936, classificou a reabsorção radicular em interna, externa e inflamatória. O processo de reabsorção interna é aparentemente desencadeado por algum sinal inflamatório na polpa. O trauma é sugerido como causa deste tipo de reabsorção, embora, o mecanismo ainda seja desconhecido. A reabsorção externa pode ser fisiológica, quando ocorre nos dentes decíduos, reabsorção dentária ortodôntica, quando decorrente do tratamento ortodôntico, reabsorção induzida por trauma, ou reabsorção causada pela pressão de um dente adjacente não irrompido. A reabsorção inflamatória pode ser apical ou cervical. A reabsorção inflamatória apical ocorre apenas em dentes não vitais e o tratamento de eleição é a endodontia, enquanto que na reabsorção radicular inflamatória cervical, a polpa pode ou não ter vitalidade, caracterizando se por uma pequena cavidade na margem cervical, podendo, mais tarde, envolver a dentina.

ANDREASEN $^{7}$, em 1985, classificou a reabsorção

* CONSOLARO, A. (Faculdade de Odontologia de Bauru, S.P.). Comunicação pessoal, 1996. 
radicular externa em 3 tipos principais, de acordo com a etiologia e a patogenia: a reabsorção de superfície causada, pela agressão ao ligamento periodontal, podendo ser reparada se a agressão não persistir; a reabsorção inflamatória, conseqüente da combinação entre agressão ao ligamento periodontal e à superfície radicular, existindo bactérias presentes no canal radicular e, por último, a reabsorção por substituição, decorrente da fusão entre o osso adjacente e a superfície radicular.

Três anos após, TRONSTAD ${ }^{133}$ distinguiu dois tipos de reabsorção inflamatória: quando o agente etiológico é mínimo e atua por um curto período, há uma reabsorção inflamatória transitória e, ao contrário, quando o fator etiológico estende se por um longo período, o autor sugere o termo reabsorção inflamatória progressiva.

Com o objetivo principal de classificar as reabsorções radiculares, PUCHE ${ }^{107}$, em 1993, realizou uma breve revista da literatura. Considerou que as reabsorções podem ser classificadas em reversíveis e irreversíveis. As reabsorções foram consideradas reversíveis quando causadas pela compressão do ligamento periodontal, resultante de uma carga oclusal excessiva e foram chamadas de irreversíveis em diferentes situações: na reabsorção fisiológica dos dentes decíduos, para serem substituídos pelos sucessores; na reabsorção de incisivos laterais superiores durante a erupção dos caninos; na reabsorção provocada pelo movimento fisiológico dos dentes e, ainda, na reabsorção idiopática.

$\mathrm{Na}$ realidade, didaticamente, é necessário que os critérios de classificação sejam bem estabelecidos. Assim, se a classificação for quanto ao mecanismo de ocorrência, as reabsorções podem ser classificadas em inflamatórias ou por substituição. As reabsorções inflamatórias decorrem de um agente agressor, que leva à lesão externa e/ou interna e pela ação de mediadores acumulados no exsudato inflamatório. As reabsorções por 
substituição são conseqüentes de uma anquilose alveolodentária prévia, havendo, na maior parte dos casos um componente inflamatório, enquanto que na reabsorção inflamatória, geralmente não há anquilose. Com o tempo, o dente vai sendo reabsorvido e a parte reabsorvida é substituída por osso, formando se novas trabéculas ósseas. O processo se estende para a coroa e para a raiz, respeitando sempre o limite pulpar, devido à presença da pré dentina. Quanto à localização, a reabsorção pode ser considerada interna, externa ou interna externa*.

Atualmente, a classificação mais utilizada em relação à movimentação dentária é a de LEVANDER; MALMGREN76 (1988), os quais classificaram as reabsorções, de acordo com a gravidade, em ausente, leve, moderada, acentuada e extrema.

De uma forma bem ampla, a reabsorção pode ser classificada ainda em fisiológica, quando ocorre nos dentes decíduos e patológica, a que ocorre nos dentes permanentes ${ }^{22,82}$.

Deste modo, pode se considerar que a reabsorção radicular decorrente do tratamento ortodôntico seja externa, inflamatória e patológica ${ }^{131}$.

\subsubsection{Etiologia}

A reabsorção radicular apical apresenta origem multifatorial. Fatores como: dentes impactados $58,67,101,110$, presença de um granuloma, cisto ou tumor ${ }^{101,110}$, forças promovidas pela língua nos incisivos $^{53,79}$, forças ortodônticas excessivas ${ }^{42,67,78,92,101,109,126,137}$, distúrbios sistêmicos e ainda, má nutrição ${ }^{44}$ podem ser responsáveis pela reabsorção

\footnotetext{
* CONSOlARO, A. (Faculdade de Odontologia de Bauru, S. P.). Comunicação pessoal, 1996.
} 
radicular101,110,126. Alguns problemas endócrinos, como o hipotireoidismo ${ }^{21}$, o hipopituitarismo ${ }^{21}, \quad$ o hiperpituitarismo ${ }^{21}$, o hiperparatireoidismo ${ }^{26}$, a hipofosfatemia ${ }^{26}$ e a doença de Paget $^{26}$ têm sido associados à reabsorção radicular.

Adicionado a esses fatores, tem sido documentado que a aspereza radicular progressiva constitui uma função normal do envelhecimento ${ }^{52,53}$, provavelmente em resposta ao uso cumulativo e à agressão, no periodonto, das forças mastigatórias e outras funções bucais. Em geral, uma mastigação pesada, como em várias civilizações não ocidentalizadas, causa maior e mais rápida reabsorção radicular. Do mesmo modo, pessoas que têm habitualmente bruxismo, ou outro meio de estresse no periodonto, tendem a mostrar dentes mais $\operatorname{curtos}^{53}$, devido à compressão do ligamento periodontal, resultante de uma carga oclusal aumentada ${ }^{110}$.

A seguir, serão abordados apenas os fatores que, associados à movimentação dentária, podem promover uma maior reabsorção radicular apical.

\subsubsection{Fatores sistêmicos}

GOLDIE; KING ${ }^{48}$, em 1984, encontraram menos áreas de reabsorção em dentes movimentados de ratos com dieta deficiente de cálcio. Mais tarde, em 1988, ENGSTRÖM; GRANSTRÖN; THILANDER ${ }^{14}$ declararam, diferentemente, que o decréscimo de cálcio está relacionado com a maior reabsorção encontrada em dentes de rato movimentados com aparelhos fixos. Por outro lado, BACCHI ${ }^{18}$, em 1994, não encontrou diferença na quantidade de reabsorção em dentes de rato, movimentados com aparelho fixo, em animais com dieta hipo, normo e hipercalcêmica. 
PHILLIPS ${ }^{101}$, em 1955, indicou que os fatores metabólicos e genéticos podem ser sugeridos como causadores de reabsorção, entretanto, considerou o registro destes casos na literatura insuficiente para validar tal afirmação.

LINGE; LINGE78, em 1983, relataram que o desequilíbrio hormonal apenas influencia o fenômeno da reabsorção, porém não pode ser indicado como agente causador do problema.

Apesar de nenhuma conclusão genética definitiva ter sido encontrada, os mecanismos de hereditariedade possíveis são o modo autossômico dominante, o modo autossômico recessivo e o modo poligênico ${ }^{92}$. Recentemente, HARRIS; KINERET; TOLLEY ${ }^{54}$ afirmaram que as diferentes quantidades de reabsorção, encontradas após o tratamento ortodôntico, podem ser determinadas pelo genótipo.

PEREIRA ${ }^{100}$, em 1995, provou que não há interferência do uso de anticoncepcionais hormonais, por via bucal, ou da gravidez, na remodelação periodontal que ocorre durante a movimentação dentária induzida. Além disso, demonstrou também que o uso de anticoncepcionais ou a gravidez não predispõem à reabsorção radicular.

Mesmo na ausência de trabalhos conclusivos, alguns autores acreditam que há pessoas com alto risco para o encurtamento radicular em ambos os arcos, as quais podem requerer uma monitorização mais cuidadosa durante a movimentação ortodôntica ${ }^{15,35,67,85}$.

\subsubsection{Fatores locais}

A movimentação de dentes traumatizados previamente $^{78,79,81,101}$, com coroas fraturadas ${ }^{101}$, restaurações inadequadas ${ }^{53}$ ou deformidades radiculares ${ }^{88,101}$, predispõe os mesmos à reabsorção radicular. 
Ainda existe divergência em relação à movimentação de dentes tratados endodonticamente. WICKWIRE et al. ${ }^{140}$, em 1974, acreditavam que estes são mais suscetíveis à reabsorção, divergindo dos achados de SPURRIER et al. ${ }^{125}$, em 1990. O efeito do aumento da densidade da dentina nos dentes desvitalizados pode ser responsável pela menor reabsorção radicular neles observada ${ }^{110}$, conforme relatados de SPURRIER et al. ${ }^{125}$, em 1990.

MALMGREN et al. ${ }^{81}$ verificaram que incisivos traumatizados, com reabsorção prévia ao tratamento ortodôntico, exibem mais reabsorção com o tratamento do que dentes não traumatizados.

Segundo ROSENBERG ${ }^{113}$, dentes com raízes parcialmente formadas apresentam intensidade de reabsorção radicular semelhante daqueles com raízes completas. HENDRIX et al. ${ }^{56}$, por outro lado, verificaram que os dentes com raízes incompletas ao início do tratamento ortodôntico mostraram menos reabsorção ao final do mesmo, em relação àqueles com raízes completas. LEVANDER; MALMGREN76 afirmaram que o grau de reabsorção radicular nos dentes com forma de pipeta é significantemente maior do que nos dentes com forma radicular normal.

O mau posicionamento dentário, a presença de mordida cruzada, ou de contato prematuro não apresentam relação com a reabsorção radicular, porém, alguns tipos de má oclusão, como a mordida aberta, estão intimamente ligados a essa patologia ${ }^{53,92}$.

Os casos comprometidos periodontalmente, os quais vão ser submetidos a tratamento ortodôntico, devem sofrer cuidados extremos, considerando se a quantidade de osso perdido e a suscetibilidade à reabsorção do paciente (história pregressa), em função da influência dos fatores locais e hormonais ${ }^{107}$.

ODENRICK; BRATTSTRÖM ${ }^{93}$ encontraram uma correlação positiva entre a reabsorção radicular grave e a onicofagia. 
Sugeriram que os dentes anteriores, dos pacientes onicófagos, fossem monitorizados radiograficamente durante o tratamento.

Apesar da maioria dos autores acreditar que as forças aplicadas aos dentes, por meio dos aparelhos ortodônticos, são as grandes responsáveis pelo desencadeamento do processo de reabsorção ${ }^{42,67,78,92,101,109,126,137}$, HARRIS; BUTLER ${ }^{53}$, em 1992, afirmaram que o tratamento ortodôntico, por si só, não é o maior contribuinte para a reabsorção. Existem outros fatores, os quais associados à aplicação de força, desencadeiam o processo. Baseados na constatação de que a reabsorção radicular provocada pelo tratamento ortodôntico geralmente é suave1,109,111,123 e na premissa de que a reabsorção radicular provocada pelo tratamento ortodôntico cessa no momento em que a força é removida $20,24,38,83,111,112,115$, diversos autores concordam que as melhoras estéticas e funcionais justificam os riscos $26,27,53,123$.

\subsubsection{Fatores associados às variáveis do tratamento}

Existem alguns fatores que, associados à aplicação de forças ortodônticas, são considerados agravantes da reabsorção radicular. A idade ${ }^{15,114,130}$, o sexo ${ }^{76}$, o tempo de tratamento ${ }^{85,93,130}$, o tipo de má oclusão65 e a movimentação de dentes com reabsorção radicular prévia ao tratamento $27,50,84$ são comumente citados.

Sobre a idade, pode se considerar que fatores como as características do ligamento periodontal e a adaptação muscular às mudanças oclusais podem ser mais favoráveis em pacientes jovens ${ }^{78}$. As estruturas de suporte do adulto reagem diferentemente quando comparadas com tecidos jovens, devido às diferenças anatômicas do adulto ${ }^{110}$. A membrana periodontal torna se menos vascularizada, sem elasticidade e o cemento torna se mais espesso, com o passar da idade110. A estrutura periodontal do adulto, 
particularmente a cortical óssea vestibular e lingual, é composta de um tecido denso lamelado, com pequenos espaços medulares. No ligamento periodontal, as células são, na sua maioria, fibrócitos com pequenos núcleos. Há poucos osteoblastos ao longo da superfície óssea. Há ainda as fortes fibras apicais da raiz, que também influenciam o movimento dentário. Sabe se que o terço apical é mais firmemente ancorado nos pacientes adultos do que nos jovens ${ }^{110}$. Essas alterações, decorrentes do envelhecimento, refletem uma maior suscetibilidade à reabsorção radicular nos adultos ${ }^{110}$. Por isso, a movimentação dentária em adultos deve ser mais cuidadosa, com forças leves e o estresse oclusal deve ser prevenido, para diminuir o risco de reabsorção ${ }^{110}$.

Em relação ao gênero, a maioria dos trabalhos não relata dimorfismo sexual. Alguns autores acreditam que as mulheres são mais suscetíveis à reabsorção radicular ${ }^{49,78,85}$. Apenas dois estudos encontraram maior suscetibilidade no sexo masculino ${ }^{19,125}$.

A respeito da relação entre a reabsorção e o tipo de má oclusão, KALLEY; PHILLIPS65 afirmaram que os pacientes com má oclusão de Classe I, de Angle, foram significantemente menos afetados pela reabsorção radicular do que os pacientes com má oclusão de Classe II ou III. HARRIS; KINERET; TOLLEY54 não encontraram relação entre a quantidade de reabsorção encontrada e o tipo de má oclusão, segundo Angle.

$\mathrm{Na}$ realidade, muitos trabalhos afirmam não existir relação direta entre o grau de reabsorção radicular, decorrente do tratamento

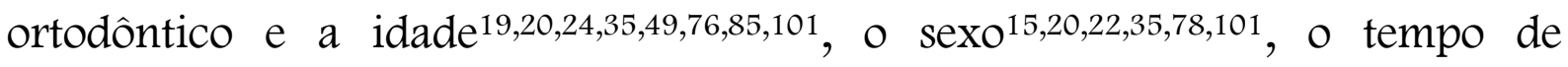
tratamento $15,20,35,76,77,78,88,101,137$, o tipo de má oclusão19,54,88,137 ou a terapia com extrações ${ }^{19,77,85,137 .}$

Dentro da mecânica ortodôntica, propriamente dita, algumas variáveis encontram se relacionadas à reabsorção radicular. Dentre 
elas estão o uso de aparelhos fixos ${ }^{1,78}$, o torque ${ }^{49}$, o uso de elásticos de Classe II $77,78,79$, a utilização de fios retangulares de aço inoxidável77,78,79, a magnitude da força aplicada ${ }^{25}$ e, principalmente, o movimento de intrusão 20,40,41,53,85, comumente citado como sendo o movimento ortodôntico responsável pela maior intensidade de reabsorção radicular. MIRABELLA; ARTUN88, em 1995, não encontraram relação entre o uso de arco retangular, a proximidade entre a raiz e o palato ou o tratamento com osteotomia da maxila e a reabsorção radicular.

O fato da magnitude da reabsorção ser imprevisível e depender de fatores múltiplos, exige do profissional atitudes clínicas coerentes, as quais abarcam um diagnóstico perfeito, uma mecanoterapia racional que respeite a biologia do periodonto e, finalmente, um controle radiográfico periapical ${ }^{100}$.

\subsubsection{O desenvolvimento do processo}

Desde muito cedo, várias teorias começaram a ser expostas, na tentativa de explicar como ocorre o processo de reabsorção radicular.

BECKS; MARSHALL ${ }^{22}$, em 1932, afirmaram que, microscopicamente, a destruição do cemento e da dentina dos dentes permanentes freqüentemente ocorre como resultado de alterações inflamatórias na membrana periodontal. Encontraram osteoclastos* em contato com o dente, aparentemente os mesmos presentes na reabsorção das

\footnotetext{
* Os osteoclastos, na maioria das vezes, consistem em células grandes, normalmente multinucleadas, formada pela fusão de precursores mononucleares. Caracterizam -se por apresentar uma borda em escova justaposta à superfície de tecido duro, quando ativos. Existe um consenso de que os osteoclastos originam se da medula óssea e que a disseminação de seus precursores ocorre pelo sistema vascular ${ }^{9}$.
} 
raízes dos dentes decíduos. Apesar disso, consideraram o processo dos dentes decíduos, fisiológico, diferentemente do processo patológico que ocorre nos dentes permanentes.

Três anos após, MARSHALL ${ }^{82}$ também admitiu existirem similaridades e diferenças entre a reabsorção patológica e fisiológica. Segundo o autor, o processo de reabsorção ocorre da seguinte maneira: a pressão nas raízes, mesmo que muito leve, produz uma hiperemia localizada na membrana periodontal e na polpa, sendo este, provavelmente, o primeiro estágio da reabsorção. É desconhecido como os tecidos afetam a solução de sais inorgânicos das estruturas duras. Se a este problema for aplicada a idéia da ação das enzimas, uma explicação similar à que segue pode ser oferecida: como resultado do trauma local causado pela pressão, a fosfatase gradualmente produz a desmineralização da área envolvida. Seguindo a descalcificação, a protease dos resíduos da matriz orgânica inicia se e então as partes orgânicas e inorgânicas dos tecidos são removidas. Ainda não se sabe qual a participação dos osteoclastos no processo.

Em 1974, REITAN109 estudou a reação tecidual na porção apical das raízes e afirmou que a reabsorção radicular ocorre na maioria dos casos em que forças são aplicadas. Entretanto, se estas forem moderadas, as lacunas de reabsorção formadas geralmente serão superficiais. Para o autor, a superfície radicular reabsorvida, com exceção da porção apical definitivamente encurtada, é reconstruída por cemento celular.

RYGH ${ }^{115}$, em 1977, afirmou que o processo de reabsorção radicular parece variar entre as pessoas e no mesmo indivíduo, em épocas distintas. Os fatores metabólicos responsáveis pelas mudanças na relação entre a atividade osteoblástica e osteoclástica são os hormônios, o tipo corpóreo e a taxa metabólica. Pode se dizer que os distúrbios nessa interação explicam a tendência individual para a reabsorção radicular. Segundo o autor, 
a reabsorção radicular ocorre simultaneamente e após a eliminação da zona hialinizada e, além disso, a camada cementóide e a maior maturação de fibras colágenas periodontais são possíveis barreiras preventivas da reabsorção radicular. Salientou também que o microambiente ao redor do tecido hialinizado é favorável à indução de células clásticas. De acordo com RYGH ${ }^{10}$, pela contínua aplicação da força ortodôntica, o processo de reabsorção continua mesmo após toda a zona hialinizada ter sido eliminada. No entanto, se a força ortodôntica for interrompida, ou cair abaixo de um certo nível, as lacunas de reabsorção serão reparadas.

ANDRESEN 8,9 , em 1988, afirmou que os osteoclastos são células indispensáveis durante a erupção dentária e a movimentação ortodôntica. Segundo o autor, a definitiva identificação do osteoclasto precursor é ainda necessária, embora evidências recentes indiquem que ele é originário de uma subdivisão das células hematopoéticas da medula óssea.

SASAKI ${ }^{118}$, no mesmo ano, em seus estudos sobre a reabsorção dos dentes decíduos humanos, verificou que durante o processo de reabsorção, uma multinucleação de osteoclastos precursores toma lugar, à distância, da superfície dentinária. Além disso, na matriz dentinária mineralizada não identificada (não reconhecida anteriormente pelo sistema imune), substâncias agem como um sinal para o desenvolvimento das bordas irritantes, cuja presença foi relacionada à descalcificação e fragmentação dos cristais de dentina. Diferentemente do mineral removido, a parte orgânica da atividade osteoclástica nunca foi completamente estudada. Os produtos de degradação resultantes da matriz de proteínas foram considerados, supostamente, um sinal químico para dirigir a atividade osteoclástica.

A importante tarefa do osteoblasto no gerenciamento da atividade do osteoclasto foi descrita por CHAMBER ${ }^{36}$, ainda em 1988, sugerindo que o controle local e sistêmico da atividade osteoclástica seja 
mediado pelas células da linhagem osteoblástica.

MYRICK JUNIOR ${ }^{91}$, também em 1988, estudando a reabsorção radicular relacionada a períodos de estresse, em espécies variadas como ursos negros, alces e golfinhos, verificou que fatores sistêmicos, sob certas condições, podem controlar a atividade osteoclástica, afetando as raízes dos dentes.

ENGSTRÖM; GRANSTRÖM; THILANDER ${ }^{44}$, no mesmo ano, estudando a reabsorção radicular em ratos, observaram lacunas de reabsorção nas zonas de compressão das regiões periodontais com atividade degradativa e reabsorção do osso alveolar nas superfícies radiculares adjacentes às zonas hialinas. Sete dias após a aplicação de força, as lacunas de reabsorção já eram visíveis nas zonas de compressão das superfícies radiculares, em ratos normais. Este estudo mostra que as reabsorções radiculares são claramente relacionadas com a reorganização que ocorre no osso alveolar e ligamento periodontal, durante o movimento dentário ortodôntico.

BLAKE; WOODSIDE; PHAROAH ${ }^{24}$, em 1995, afirmaram que a eliminação da área de tecido comprimido hialinizado é realizada pela invasão de células e vasos sangüíneos vindos do periodonto sadio adjacente, ocorrendo a remoção tanto do tecido cementóide, quanto da matriz colágena adjacente ao cemento, com subseqüente alteração da barreira normal da reabsorção da raiz. Segundo os autores, a reabsorção externa de raiz é iniciada 14 a 20 dias após a aplicação da força ortodôntica e pode continuar enquanto esta persistir. Após a remoção da força, no entanto, a superfície é reparada.

A teoria da auto imunidade, comumente associada ao processo de reabsorção, indica que a dentina é protegida internamente pelos odontoblastos e externamente pelo esmalte. O cemento intermediário ou 
proteína "esmalte like", fina camada de proteína de matriz orgânica, produzida pela bainha de Hertwig, durante a formação da raiz, protege a dentina da exposição direta às células do futuro ligamento periodontal. A fragmentação da bainha de Hertwig não expõe dentina, porque antes de fragmentar se, ela forma o cemento intermediário que a protege. $\mathrm{Na}$ odontogênese normal, não há exposição de dentina ao sistema imune. Por este motivo, se houver exposição de dentina na região do ligamento periodontal, esta será reconhecida como proteína estranha. Na movimentação dentária, o cemento, em função da sua fragilidade e de sua fina espessura (20 a $50 \mu \mathrm{m}$ na região cervical e 200 a $400 \mu \mathrm{m}$ na região do ápice ${ }^{14}$ ), rapidamente expõe a dentina. Toda vez que houver dentina exposta, haverá reabsorção. Na área desnuda de dentina, os osteoclastos chegam rapidamente e os osteoblastos, somente horas após. A remoção da força faz com que os osteoclastos cedam lugar aos osteoblastos, promovendo o reparo, originado pela migração de cementoblastos sobre a superfície reabsorvida, competindo pela superfície disponível e excluindo os osteoblastos e os clastos ${ }^{63}$.

Publicações recentes indicam que a reabsorção dos tecidos dentinários mineralizados tem início quando os osteoclastos conseguem acesso aos tecidos mineralizados por uma brecha na camada de células formativas que recobrem o tecido $63,133,139$, quando o pré cemento é lesado mecanicamente ${ }^{133}$. Os tecidos não mineralizados, osteóide, pré cemento e pré dentina mostram se resistentes à reabsorção e podem, inicialmente, prevenir a perda de tecido radicular 53,110 . Contudo, a pressão contínua finalmente induzirá à reabsorção dessas áreas ${ }^{110}$. Sabe se que os osteoclastos são responsáveis tanto pela desmineralização de tecido, como pela degradação da matriz orgânica após a desmineralização63 e sabe se que os osteoblastos contém receptores para a maioria dos agentes reabsorvedores, reconhecendo e transmitindo aos clastos o comando para estes realizarem a reabsorção ${ }^{87}$. Os osteoblastos respondem aos hormônios envolvidos na manutenção da 
homeostasia do cálcio, tais como o paratormônio, a calcitonina e a vitamina D,bem como aos agentes produzidos localmente, como as citocinas ${ }^{26}$.

Recentemente, afirmou se que a atividade de reabsorção, como uma resposta das células do ligamento periodontal ao estímulo mecânico ou químico, é caracterizada pela síntese de prostaglandina. Esse processo é regulado por hormônios (da paratireóide e calcitonina), por neurotransmissores e por citocinas ${ }^{26}$.

No processo de reabsorção, as dimensões originais do dente não são restabelecidas, o que implica, geralmente, em redução no seu comprimento. O encurtamento ocorre da seguinte maneira: com o início da reabsorção, regiões pontiagudas são formadas no ápice. Com os movimentos de intrusão e extrusão do dente no alvéolo, uma microlesão forma se no tecido periodontal, provocando ou exacerbando a inflamação, tendendo a uma regularização do ápice, promovendo a reabsorção e a diminuição do comprimento radicular. Enquanto não houver a regularização do contorno do ápice, até que a superfície se torne compatível com a fisiologia da área, o processo não cessa. Portanto, sempre haverá um encurtamento do dente, em maior ou menor grau, dependendo da gravidade do processo. O reparo é realizado às custas de tecido de granulação, de migração celular e de todo o envolvimento do ligamento periodontal que vai depositar cemento*.

\footnotetext{
* CONSOlARO, A. (Faculdade de Odontologia de Bauru, S. P.). Comunicação pessoal, 1996.
} 


\subsubsection{Reabsorção radicular associada à movimentação dentária induzida}

\subsubsection{Estudos em animais e mistos}

As pesquisas de movimentação dentária induzida inicialmente foram realizadas em cães e em macacos. $O$ pioneiro em experimentos de movimentação dentária induzida em animais foi SANDSTEDT ${ }^{117}$, em 1904. Induzindo a movimentação em incisivos superiores de um cão, encontrou deposição óssea no lado de tensão e reabsorção alveolar no lado submetido à pressão. O ligamento periodontal, sob forças pesadas, foi comprimido no lado de pressão, iniciando uma reabsorção nos espaços medulares contíguos ao osso alveolar, denominando se, esse processo, de reabsorção à distância.

OPPENHEIM $^{94}$ foi o primeiro investigador a ter seus estudos histológicos reconhecidos e, desde 1911, seu trabalho tem servido como critério na prática clínica ${ }^{100}$. Objetivando discutir as alterações teciduais frente ao movimento dentário, instalou um aparelho nos dentes decíduos de um babuíno. A força foi aplicada, por 40 dias, em um lado do arco e o outro serviu de controle. Foram realizados os movimentos de intrusão, extrusão e inclinação para vestibular e lingual. Em todos os movimentos encontrou uma reorganização da arquitetura óssea, com as espículas ósseas organizadas paralelamente em direção à força. Afirmou que os efeitos dos aparelhos no osso e nos outros tecidos são similares no homem, quando utilizados em condições de normalidade.

Em 1932, SCHWARZ120, estudando a reação dos tecidos envolvidos na movimentação dentária em cães, com diferentes intensidades de força, encontrou quatro graus de efeitos biológicos, em função das forças empregadas. O primeiro grau é caracterizado por forças suaves e breves, as 
quais não causam nenhuma reação no periodonto. Uma força suave, ligeiramente inferior ou igual à pressão capilar, por volta de 20 a 26 gramas $/ \mathrm{cm}^{2}$ de superfície radicular para o homem, provocando uma reabsorção óssea contínua, estabelece o segundo grau. O terceiro grau é determinado por uma força relativamente intensa, superior à pressão capilar sangüínea, causando compressão dos capilares sangüíneos, com isquemia e reabsorção das partes necrosadas, podendo até comprometer a integridade da superfície radicular. Quando a força é suprimida, o osso alveolar, o periodonto, assim como a superfície radicular, reconstituem $\sim$ se funcionalmente, podendo ocorrer reabsorção dentinária. Finalmente, o quarto grau ocorre quando há uma força muito intensa que comprimiu o periodonto na área de pressão, submetendo o dente ao contato com o osso alveolar. Há reabsorção óssea local, assim como à distância e a superfície dentinária torna se mais propensa a ser reabsorvida. Após a remoção da força, além das reações ocorridas no $3^{\circ}$ grau, há a possibilidade de necrose pulpar e anquilose alveolodentária.

STUTEVILLE128, em 1938, analisou microscopicamente os dentes de 14 jovens e 64 cães. Os dentes foram movidos com forças ativas, por distâncias determinadas, com o objetivo de verificar as alterações que ocorrem nos dentes e nos tecidos de suporte, após a movimentação dentária induzida. De acordo com o autor, as estruturas mais afetadas com a movimentação foram a membrana periodontal, a superfície da raiz, o osso alveolar, a gengiva e a polpa. Analisando as lâminas obtidas, o autor encontrou reabsorção radicular praticamente em todos os casos tratados ortodonticamente, mas em maior número nos casos com aparelhos removíveis, em função dos movimentos de vai e vem. STUTEVILLE ${ }^{128}$ salientou que outros fatores importantes devem ser analisados em relação à força aplicada, como a quantidade e o tipo de força, a distância na qual a força permanece ativa e a presença de outras forças, além daquelas exercidas pelo aparelho. 
Anos mais tarde, em 1977, RYGH ${ }^{115}$ ressaltou que a reabsorção e o encurtamento radicular podem ser conseqüências indesejáveis do tratamento ortodôntico. Induziu o movimento dentário em 67 ratos Wister, de ambos os sexos, produzindo uma força constante e equivalente a 5, 10 ou 25 gramas, para vestibular, em um dos molares com aparelho fixo. Além disso, realizou um experimento com 11 pré molares humanos, também movidos em direção vestibular, por meio de aparelhos fixos. As forças, nesses casos, foram de 70, 100, 120 e 240 gramas. Ao final do período experimental, as amostras contendo dentes, ligamento periodontal e osso alveolar foram processadas para microscopias de luz e eletrônica. RYGH115 constatou a continuidade do processo de reabsorção mesmo após a eliminação de toda a zona hialinizada. Entretanto, quando a força ortodôntica foi interrompida ou diminuída, houve reparo das lacunas de reabsorção.

GOLDIE; KING ${ }^{48}$, em 1984, compararam o movimento dentário, a extensão da perda óssea mineral e as áreas de superfície radicular em animais estressados, com grave deficiência de cálcio e em lactação e também em animais não estressados, com dieta balanceada. Utilizaram 35 ratas adultas, Sprague Dawley, divididas em 2 grupos: o grupo controle, formado por 10 animais com dieta equilibrada e o grupo teste, formado por 25 ratas que estavam amamentando, com dieta deficiente em cálcio. Uma força de 60 gramas foi aplicada para inclinar os molares superiores mesialmente, em diferentes períodos. Os resultados encontrados confirmaram observações anteriores de que a lactação associada à deficiência de cálcio pode produzir decréscimo na densidade óssea, juntamente com aumento na secreção de hormônios da paratireóide. O íon cálcio apresentou um importante papel na mediação dos efeitos do estímulo externo (força, hormônios) sobre as células alvo. Além disso, o decréscimo da área de reabsorção radicular nos animais hipocalcêmicos sugeriu que a reabsorção óssea aumentada e a densidade óssea reduzida facilitaram a movimentação dentária. 
FOLLIN; ERICSSON; THILANDER ${ }^{46}$, em 1986, realizaram um estudo experimental em cães, nos quais 15 dentes foram movidos de corpo por um período de 100 dias e 9 dentes foram inclinados por 180 dias, com a mesma quantidade de força horizontal. Os aparelhos utilizados foram os da técnica do Arco de Canto, cimentados nos quartos pré molares e nos primeiros molares inferiores, exercendo uma força, em todos os dentes, de 40 a 70 gramas. Os autores constataram reabsorção mais grave quando o dente foi movido de corpo do que quando foi inclinado, embora o movimento de inclinação tenha sido mais extenso e que a raiz distal sofreu mais reabsorção do que a mesial, independentemente do tipo de movimento realizado. Salientaram a importância da utilização de forças mais leves em regiões pouco vascularizadas, como no segmento ântero inferior.

ENGSTRÖM; GRANSTRÖM; THILANDER ${ }^{44}$, em 1988, com o objetivo de investigar os efeitos das forças ortodônticas nos tecidos periodontais, usando métodos histológicos e bioquímicos, em ratos normais e com deficiência em cálcio, utilizaram 160 ratos Sprague Dawley, divididos em 2 grupos. Do grupo 1 faziam parte 80 ratos com dieta normal, enquanto no grupo 2 estavam 80 ratos com dieta deficiente em cálcio e com hiperparatiroidismo secundário*. A reabsorção radicular foi induzida nos incisivos superiores dos ratos, em ambos os grupos, por meio de forças ortodônticas moderadas. Em ambos, a reabsorção das raízes ocorreu nas adjacências das áreas de reorganização do ligamento periodontal, com atividades degradativas e reabsorção do osso alveolar. Sete dias após iniciada a aplicação de força, as lacunas de reabsorção já eram visíveis nas zonas de compressão das superfícies radiculares em ratos normais. Embora as lacunas de reabsorção tenham sido observadas em localização similar, nos dois grupos, nos dentes dos ratos hipocalcêmicos elas apareceram antes. Além disso, nesse

\footnotetext{
* O hormônio paratireoídeo tem sido relacionado ao aumento do número de osteoclastos presentes no ligamento periodontal, ou seja, há um aumento do movimento dentário em indivíduos com hiperparatireoidismo, mas nada ainda foi demonstrado em relação à reabsorção das raízes ${ }^{44}$.
} 
grupo, houve aumento da reabsorção óssea alveolar e das zonas de compressão mais rápido e mais extenso, após a aplicação da força, do que nos ratos normais, como indicado pelo aumento na média de movimento dentário. O aumento na reabsorção radicular observado no grupo com hipocalcemia pode ser relacionado ao aumento da atividade de reabsorção óssea, se comparado com o grupo normal. De acordo com os autores, foi necessário um decréscimo do nível de cálcio para ocorrer a reabsorção. Este estudo demonstrou que as reabsorções radiculares foram claramente relacionadas com a reorganização do osso alveolar e do ligamento periodontal durante o movimento dentário ortodôntico. O aumento da gravidade na reabsorção após o tratamento ortodôntico foi relacionado ao aumento da reabsorção óssea alveolar. A reabsorção acentuada, vista em aproximadamente 10\% das pessoas sem tratamento, pode ser causada por diferentes médias de renovação óssea dessas pessoas com aquelas que não apresentam ou que apresentam reabsorção leve após o tratamento ortodôntico. Os autores recomendaram uma monitorização cuidadosa da progressão inicial do movimento dentário e um exame radiográfico regular durante o tratamento, especialmente em usuários de medicamentos que afetam a atividade metabólica nos tecidos periodontais.

Dois anos mais tarde, BRUDVIK; RYGH ${ }^{28}$, com a proposta de investigar a ocorrência de reabsorção radicular ortodôntica em decorrência da injeção local de prostaglandina $\mathrm{E}_{2}\left(\mathrm{PGE}_{2}\right)$, induziram a movimentação dentária em 25 ratos Wistar. Os animais foram divididos em 2 grupos: o primeiro, o grupo controle, que compreendeu 6 animais, nos quais nenhuma força foi aplicada, um animal (controle puro), no qual a prostaglandina não foi injetada e 5 animais, nos quais $0,1 \mathrm{ml}$ de $0,1 \mu \mathrm{g} / \mu 1$ $\mathrm{PGE}_{2}$ foi injetado. O segundo foi o grupo experimental, que consistiu de 19 animais. A duração do período experimental foi de 3 (6 animais), 7 (7 animais) e 10 (6 animais) dias. Os primeiros molares superiores de ambos os lados foram movidos mesialmente por meio de uma mola, com uma força de 
50 gramas. Imediatamente após a aplicação da força, as injeções de prostaglandina foram realizadas apenas no hemi arco direito do animal. A $\mathrm{PGE}_{2}$ foi injetada na gengiva, no lado vestibular do primeiro molar, nos dias 0 , 3, 5 e 7. No lado esquerdo nenhuma injeção foi aplicada. Os animais foram sacrificados depois de 3 dias. Após a análise dos resultados obtidos, os autores não encontraram diferença significante na reabsorção radicular entre os dentes experimentais movidos, com e sem injeção de prostaglandina, mas apenas uma maior tendência à reabsorção foi registrada nos dentes em que a injeção foi realizada.

BRUDVIK; RYGH29, em 1993, com o objetivo de estudar mais detalhadamente a superfície radicular durante a penetração inicial de células no pré cemento e no cemento mineralizado, em 21 ratos Wistar, movimentaram mesialmente o primeiro molar superior, por meio de uma mola fechada, por 6 e 12 horas, durante 1, 2, 3, 4 e 5 dias. Os resultados claramente indicaram que houve um padrão para as células mononucleadas não clásticas, na remoção inicial do pré cemento e do cemento acelular mineralizado. Após 6 horas, encontraram células "macrófagos like" fagocitando o tecido necrótico no meio do ligamento periodontal e 24 horas depois, próximas à superfície radicular, quando também visualizaram células "fibroblastos like", próximas à zona hialina, quebrando o pré cemento, pela fagocitose e pela atividade de colagenase. Observaram, após esse mesmo tempo, as camadas de superfície de cemento mineralizado sendo removidas por células mononucleadas, as quais apareceram no cemento mineralizado após 3 dias e ainda encontraram células multinucleadas sem borda em escova, no ligamento periodontal, à mesma distância da superfície radicular. Raramente detectaram a presença de células multinucleadas com uma borda em escova dispostas na superfície radicular mineralizada, durante o período de 5 dias.

BACCHI ${ }^{18}$, em 1994, visando verificar o grau de comprometimento das estruturas periodontais diante de dieta hipoprotéica e 
da movimentação dentária, a capacidade de resposta dos tecidos periodontais frente à ação mecânica de movimentação dentária, nas condições de subnutrição protéica e a existência ou não de relação entre as variáveis acima consideradas e o fenômeno da reabsorção radicular dentária externa, utilizou 45 ratos (Rattus norvergicus, albinus, Wistar), com 21 dias de idade. Os animais foram divididos em 3 grupos de 15 ratos em cada um, com dieta hipo, normo e hiperprotéica. Cada grupo foi subdividido em 3 grupos de 5 animais, aos quais foram adaptados dispositivos capazes de produzir movimentação dentária por períodos de 1, 3 e 7 dias. Os graus de movimentação do primeiro molar superior direito de cada animal foram registrados em radiografias, por meio de processo histológico e por microscopia ótica convencionais, realizando uma análise detalhada do osso alveolar, do ligamento periodontal e da superfície radicular. Após a análise do material obtido, o autor verificou, nos animais mantidos sob dieta hipoprotéica, um menor grau de movimentação dentária durante os 3 períodos experimentais, a ocorrência de osteoporose do osso alveolar, dificuldade e desorganização nas respostas do tecido ósseo, movimentação dentária mais efetiva, respostas menos organizadas e mais lentas do ligamento periodontal frente à aplicação de força e ainda detectou sinais de presença de maior número de lacunas de reabsorção "ativa". O fenômeno da reabsorção dentária externa não exibiu diferenças consideráveis entre os animais dos 3 grupos avaliados.

BRUDVIK; RIGH ${ }^{30}$, no mesmo ano, com o objetivo de estudar detalhadamente, em microscopia eletrônica de varredura, as células envolvidas na remoção do tecido hialinizado e aquelas envolvidas na reabsorção radicular, utilizaram 20 ratos Wistars, com 40 a 45 dias de idade, movendo mesialmente os primeiros molares superiores por meio de aparelho fixo, constituído de molas fechadas de Elgiloy, liberando uma força de 50 gramas. As molas não foram reativadas durante o período experimental. Os primeiros molares superiores contralaterais e ambos os segmentos de um 
animal que não usou nenhum tipo de aparelho serviram de controle. O período experimental foi de 7 e 10 dias após o qual os animais foram sacrificados e secções no sentido mesiodistal de 2 a $4 \mu \mathrm{m}$ foram realizadas. Os resultados revelaram que células multinucleadas gigantes sem borda em escova, assim como "macrófagos like" mononucleados, foram responsáveis pela remoção de tecido necrótico e também pela reabsorção de partes da superfície do cemento radicular. "Clastos like" multinucleados com borda em escova nunca foram observados próximos aos remanescentes de tecido necrótico, sendo encontrados somente nas lacunas de reabsorção na raiz e nas superfícies ósseas.

Visando determinar a dose ótima de $\mathrm{PGE}_{2}$ para aumentar o movimento dentário com uma reabsorção radicular mínima, assim como determinar os efeitos de repetidas doses, em um longo período de tempo (4 semanas), LEIKER et al. ${ }^{75}$, em 1995, utilizaram 132 ratos Sprague Dawley, com 8 semanas de idade, nos quais 4 doses diferentes foram injetadas: 0,$1 ; 1$; 5 e $10 \mu \mathrm{g}$. Cinco ratos foram utilizados em um estudo piloto, 7 serviram de controle puro e 8 de controle com aparelho. Os 112 restantes foram divididos em 2 grupos controle (de 28 animais cada) e 2 experimentais (de 28 animais cada). Cada grupo foi subdividido em 2 grupos de 14 animais, baseando se na concentração de prostaglandina $\mathrm{E}$ injetada. $\mathrm{O}$ aparelho fixo utilizado apresentava uma mola fechada de níquel titânio entre os incisivos centrais e os primeiros molares superiores e uma força inicial de 60 gramas foi aplicada. Todos os animais foram sacrificados após 4 semanas e os seus dentes, examinados por microscopia eletrônica. Os resultados mostraram que a injeção de prostaglandina E, em ratos, por extensos períodos de tempo, independentemente da dose aplicada, aumentou a quantidade de movimento dentário. Entretanto, não houve diferença estatisticamente significante no movimento dentário entre os grupos de injeção simples ou dupla, ou entre os 4 níveis de concentração da droga, usados nos períodos de 2 ou 4 semanas. As 
concentrações mais altas de $\mathrm{PGE}_{2}$ aumentaram a reabsorção radicular, assim como as injeções múltiplas da droga.

BRUDVIK; RIGH ${ }^{31}$, em 1995, objetivando registrar e analisar os determinantes que podem influenciar na extensão da superfície radicular reabsorvida, assim como o processo de transição entre a reabsorção ativa e o reparo, utilizaram um modelo experimental, simulando o primeiro ciclo de ativação de força, movendo mesialmente primeiros molares superiores de ratos por meio de aparelho fixo, constituído de molas fechadas de Elgiloy, liberando uma força de 50 gramas. Os animais utilizados foram 24 ratos Wistars, com 40 a 45 dias de idade, divididos em 1 grupo controle e 6 experimentais. O período experimental foi de $2,3,7,10,14$ e 21 dias e não houve reativação da mola durante este período. Os primeiros molares superiores contralaterais e ambos os segmentos de um animal que não usou nenhum tipo de aparelho serviram de controle. Após o período experimental, os animais foram sacrificados e secções no sentido mesiodistal de $6 \mu \mathrm{m}$ foram realizadas. Os resultados revelaram que: a extensão de superfície reabsorvida após 21 dias correspondeu à extensão máxima de zona hialinizada; o processo de reparo iniciou se na periferia enquanto a reabsorção ativa ainda persistia no centro e também que a reabsorção continuou na área onde o tecido hialinizado persistiu, mesmo após a remoção da força. Constataram que os determinantes do processo de reparo estão associados à persistência e à remoção do tecido necrótico.

No mesmo ano, BRUDVIK; RIGH ${ }^{32}$, por meio da microscopia eletrônica, estudaram mais detalhadamente as lacunas de reabsorção durante o processo de reparo. Vinte ratos Wistar, de 40 a 45 dias de idade, divididos em 1 grupo controle e 3 grupos experimentais, foram utilizados. Os primeiros molares superiores direitos foram movidos mesialmente pelo mesmo aparelho utilizado em trabalhos anteriores ${ }^{30,31}$, por períodos experimentais de 10, 14 e 21 dias. Após o período experimental, os 
animais foram sacrificados e secções de 2 a $4 \mu \mathrm{m}$ foram realizadas. Os resultados indicaram que a transição da força ativa para passiva, no processo de reparo, está associada à invasão de "fibroblastos like" no sítio da reabsorção ativa. Mostraram, após 10 dias, a formação de novas estruturas de suporte na periferia das lacunas de reabsorção, enquanto a reabsorção ativa, realizada por "clastos like" multinucleados, iniciava nas partes centrais. Nas fases tardias, após o término da força, o processo de reparo foi similar ao processo que ocorre na cementogênese ocorrida durante o desenvolvimento dentário. Um novo cemento mineralizado foi observado na superfície radicular após 21 dias. Com a deposição desse novo cemento, as estruturas do novo ligamento periodontal restabelecidas foram comparáveis às do espécime controle.

PEREIRA ${ }^{100}$, também em 1995, buscando encontrar uma relação conclusiva entre a movimentação dentária induzida e o uso de anticoncepcionais hormonais, por via bucal e a gravidez, estudou, experimentalmente, em ratas, os efeitos da movimentação dentária induzida por aparelhos ortodônticos. A amostra constou de 35 ratas Wistar, com idade entre 90 e 120 dias, divididas em 7 grupos: três de ratas prenhes, dois de ratas recebendo anticoncepcional e 2 grupos controle, um com e outro sem movimentação dentária. Os resultados da análise microscópica dos tecidos envolvidos mostraram um padrão constante em todos os grupos experimentais, não permitindo qualquer inferência quanto a uma alteração decorrente da prenhez ou do uso de anticoncepcional. O mesmo foi obtido na avaliação dos resultados dos traçados dos contornos ósseos e radiculares envolvidos na movimentação dentária, bem como das áreas do ligamento periodontal. Deste modo, o autor verificou que não há interferência do uso de anticoncepcionais hormonais, por via bucal e da gravidez na remodelação óssea periodontal, durante a movimentação dentária induzida e que esses fatores não predispõem os dentes ao fenômeno da reabsorção. 


\subsubsection{Estudos em humanos}

\subsection{Estudos microscópicos}

HERZBERG ${ }^{57}$, em 1932, visando extrapolar os resultados de OPPENHEIM ${ }^{94}$ para humanos, analisou o movimento dentário em uma jovem de 18 anos de idade. A movimentação foi realizada no primeiro pré molar superior direito, em direção lingual, por 70 dias. O dente contralateral serviu de controle. Ambos foram removidos juntamente com os respectivos processos alveolares e seccionados no sentido vestibulolingual. No dente movimentado, encontrou a formação de espículas ósseas no lado de tensão, dispostas paralelamente, em direção à aplicação da força e cada espícula mostrava aposição e reabsorção de tecido ósseo. No dente controle não houve alterações significantes. O autor concluiu que as alterações no osso alveolar humano, decorrentes da movimentação induzida, são as mesmas encontradas em animais experimentais.

Em 1974, REITAN ${ }^{109}$ estudou a reação tecidual na porção apical das raízes de 72 pré molares humanos, obtidos de 32 pacientes de 9 a 16 anos, os quais foram submetidos a forças com duração, direção e magnitude variadas. O grupo controle foi formado por 20 dentes dos mesmos pacientes (que não receberam força), os quais foram removidos e examinados para comparação. As forças aplicadas variaram de 25 a 240 gramas e o período experimental variou entre 10 e 47 dias. Verificou que a reabsorção radicular ocorre na maioria dos casos de aplicações de forças, no entanto, quando estas são moderadas, as lacunas de reabsorção formadas são superficiais. De acordo com o autor, a superfície radicular reabsorvida, com exceção da porção apical definitivamente encurtada, é reconstruída por cemento celular.

Por meio de uma biópsia humana, WEHBEIN, FUHRMANN; DIEDRICH ${ }^{138}$, em 1995, analisaram a maxila de uma jovem de 
19 anos, morta em um acidente. O tratamento ortodôntico, realizado com a técnica do Arco de Canto, durou 19 meses. A documentação ortodôntica disponível incluía os modelos iniciais, a telerradiografia inicial, os modelos intermediários (10 meses de tratamento), a telerradiografia intermediária (19 meses de tratamento), a ficha de procedimentos e a documentação do tamanho, qualidade e seqüência dos fios. Os autores compararam os achados histológicos, com relação ao tipo e à extensão do movimento dentário sagital, aos achados macroscópicos do osso alveolar e aos achados radiográficos. Verificaram a ausência dos segundos pré molares e do incisivo lateral direito e somente os dentes 14, 16, 17, 24, 26 e 27 foram analisados. Havia uma atrofia do osso alveolar pré terapêutica, para aonde o primeiro molar esquerdo havia sido movimentado, correspondente à região da ausência do segundo pré molar. Pelo exame radiográfico, observaram um seio maxilar extenso, em sentido basal, na direção do movimento, à frente do segundo molar esquerdo. Extensas reabsorções laterais foram detectadas na região vestibular das raízes do primeiro molar. Histologicamente, verificaram deiscências ósseas na cortical vestibular, que não poderiam ser diagnosticadas pela inspeção macroscópica. Os resultados desse estudo ilustram que a resposta periodontal, induzida pela terapia ortodôntica e as alterações histológicas dependem fortemente do tipo de movimento dentário e da estrutura óssea. Observaram que a translação pura, com o aparelho do Arco de Canto, resulta em lesões relativamente menores aos tecidos duros das raízes. No caso de movimento mesial translatório de dentes multirradiculares, o processo de reabsorção foi mais pronunciado na raiz mesiovestibular do que na raiz distovestibular. Reparos extensos também ocorreram nas raízes. Concluíram que o movimento de translação é o que menores danos causa aos tecidos, que o movimento de intrusão pode estar relacionado com a reabsorção radicular apical extrema e que o movimento de inclinação também leva às reabsorções apicais radiculares. Além disso, demonstraram que as reabsorções radiculares laterais 
são passíveis de reparação cementária, desde que não haja perfuração da cortical óssea e, principalmente, que as mudanças verificadas histologicamente são substancialmente mais pronunciadas do que as avaliações radiográficas e macroscópicas sugerem. Justificaram que as respostas histológicas induzidas ortodonticamente, verificadas no ser humano, eliminam a necessidade de discussão da transferibilidade de um modelo animal.

Visando estudar o potencial de reparo da reabsorção dentária induzida ortodonticamente, OWMAN MOLL; KUROL; LUNDGREN ${ }^{97}$, ainda em 1995, analisaram microscopicamente 64 primeiros pré molares superiores de 32 pacientes (15 do sexo masculino e 17 do feminino), com idade média de 13,7 anos, variando entre 11,3 e 17,3 anos. Os dentes foram movidos para vestibular com um aparelho fixo, utilizando um arco de Sentalloy 0,018 polegada e força horizontal contínua de 50 gramas, reativada semanalmente, por 6 semanas. Depois disso, um arco passivo de Elgiloy foi instalado e mantido como contenção, por um período que variou de 1 a 8 semanas. Ao final do período experimental, os dentes foram extraídos com fórceps e analisados histologicamente. Os preparos histológicos mostraram que a reabsorção radicular afetou todos os dentes teste. A porcentagem de áreas de reabsorção que já haviam iniciado o reparo variou de $28 \%$, após a primeira semana de contenção, a $75 \%$, após 8 semanas. O cemento reparador foi basicamente do tipo celular. Durante as primeiras 4 semanas de contenção, freqüentemente o reparo encontrado foi parcial (17\% a 31\%). Um reparo funcional, com a superfície total das cavidades de reabsorção coberta com cemento, ocorreu após 5, 6, 7 e 8 semanas de contenção (33\% a 40\%). Não houve diferenças no potencial de reparo nos terços cervical, médio e apical da raiz. Após 8 semanas, 3 ou 4 áreas de reabsorção mostraram o mesmo grau de reparo. As variações individuais no processo de reparo foram grandes.

OWMAN MOLL; KUROL; LUNDGREN ${ }^{96}$, no mesmo ano, analisaram histologicamente 32 primeiros pré molares superiores de 16 
pacientes ( 8 do sexo masculino e 8 do feminino), com idade média de 13,9 anos, variando entre 11,8 e 15,8 anos. Os dentes foram movidos para vestibular com um aparelho fixo com características idênticas ao utilizado no trabalho anterior ${ }^{97}$. Cada paciente, em ambos os grupos, teve um dos seus primeiros pré molares movidos com força contínua e os outros com força interrupta. A força aplicada nos pré molares contralaterais foi contínua, reativada semanalmente e liberada durante 3 semanas, após as quais um arco passivo foi colocado por uma semana. Os movimentos dentários foram estudados em modelos e ao final de 7 semanas verificaram que o movimento dentário horizontal com força contínua foi mais efetivo do que o com força interrupta. As secções histológicas dos dentes experimentais, entretanto, não apresentaram diferença na quantidade ou na gravidade de reabsorção radicular entre os dois tipos de força. As variações individuais na magnitude de força e na quantidade e gravidade de reabsorção radicular, para ambos os sistemas de força, foram grandes.

Visando apresentar um modelo experimental humano, designado para o controle do movimento dentário ortodôntico e, por meio desse modelo, estudar os efeitos de uma força horizontal, contínua e controlada no padrão de movimento dentário, LUDGREN; OWMAN MOLL; KUROL ${ }^{80}$, em 1996, utilizaram 120 pré molares superiores de 56 jovens, 18 do sexo masculino e 38 do feminino, com idade entre 10,5 e 17,5 anos, com uma média de 13,8 anos. O aparelho fixo utilizado era constituído de bandas nos primeiros molares superiores, uma barra transpalatina para reforço de ancoragem e ainda, um arco lingual com um bite block soldado às bandas dos molares para minimizar as forças oclusais. O primeiro e o segundo pré molares foram movidos para vestibular com um arco seccionado de Sentalloy 0,018 polegada e os pré molares contralaterais serviram de controle. Uma força de 50 gramas controlada e reativada semanalmente foi aplicada. Os pacientes foram divididos em 7 grupos, cujo período experimental variou de 1 a 7 semanas. 0 deslocamento dos dentes foi estudado em modelos. Nos dentes do grupo teste, 
os autores verificaram uma combinação de movimento vertical e horizontal, incluindo a inclinação. O movimento horizontal da coroa dentária foi, em média, 0,8 $\mathrm{mm}$ durante a primeira semana e 3,7 $\mathrm{mm}$ após 7 semanas. Os movimentos verticais foram intrusivos em $45 \%$ e extrusivos em 55\% dos dentes e foram encontradas variações individuais consideráveis nos deslocamentos dentários. Os autores concluíram que o modelo experimental utilizado permite estudar detalhadamente o movimento dentário e as análises histológicas da reabsorção radicular conseqüente desses movimentos.

OWMAN MOLL; KUROL; LUDGREN ${ }^{98}$, no mesmo ano, visando estudar a reabsorção radicular, em adolescentes, após a aplicação de uma força contínua, bem controlada e de magnitude clinicamente relevante, induziram o movimento vestibular em 112 pré molares superiores de 18 jovens do sexo masculino e 38 do feminino, por meio de um aparelho fixo. Os pacientes apresentavam uma idade média de 13,8 anos, variando de 10,5 a 17,5 anos. Os dentes foram movidos com uma força de 50 gramas reativada semanalmente, sendo que os pré molares contralaterais serviram de controle. Radiografias periapicais com a técnica do paralelismo foram obtidas uma semana antes do movimento ter iniciado e imediatamente após as extrações dos dentes. O período experimental variou de 1 a 7 semanas, quando, os dentes foram extraídos, preparados histologicamente e analisados. Os autores verificaram um aumento definido na profundidade e na extensão da reabsorção radicular, depois de 2 semanas. No início da terceira semana, 8 dentes exibiram reabsorção apical que se estendia até à metade da distância entre a superfície externa e o canal radicular, ou mais. Após 7 semanas, o grupo teste mostrou, em média, aproximadamente, 20 vezes mais reabsorção do que o grupo controle. Perceberam que as radiografias falharam em revelar algumas reações teciduais adversas e concluíram que a grande variação individual na reabsorção radicular, em associação à quantidade de movimento 
dentário, indica que fatores individuais não conhecidos influenciam nas reações dos tecidos.

\subsection{Estudos clínicos e radiográficos}

Embora, de acordo com REITAN ${ }^{108}$, a reabsorção radicular apical tenha sido primeiramente demonstrada por Schwarzkopf, em dentes extraídos, em 1887, foi OTOLLENGUI ${ }^{95}$, em 1914, quem relacionou a reabsorção radicular apical ao tratamento ortodôntico.

Foi KETCHAM 67 , no entanto, em 1927, o primeiro investigador a comprovar radiograficamente essa relação. Comparando radiografias periapicais, pré e pós tratamento, de 385 casos tratados ortodonticamente com diferentes técnicas (pino tubo, arco cinta associado a bráquetes, aparelho vestibular e aparelho lingual), encontrou reabsorção radicular apical em $21 \%$ dos dentes anteriores examinados. Para o autor, os dentes permanentes não tratados ortodonticamente raramente apresentam reabsorção. KETCHAM ${ }^{67}$ acreditava existir uma suscetibilidade individual aos distúrbios ocorridos durante o tratamento ortodôntico, sendo os dentes ântero superiores os mais suscetíveis à reabsorção. Também não encontrou uma relação apurada entre o tipo de aparelho utilizado e a reabsorção radicular apical. Declarou que o grau de imobilidade aplicado ao dente pelo aparelho, ou seja, o quanto essa imobilização interfere nas funções normais e por quanto tempo ela persiste, são fatores importantes a serem considerados pelo ortodontista no estudo da reabsorção radicular. KETCHAM ${ }^{67}$ fez um alerta sobre a importância das radiografias periapicais serem tomadas ao início e durante o tratamento.

Desde então, diversos estudos clínicos e radiográficos, com diferentes metodologias, relacionando a reabsorção radicular apical às diversas técnicas de tratamento ortodôntico, têm sido realizados $1,2,15,19,20,24,33,35,41,42,49,51,52,53,54,55,56,65$, $68,73,76,77,78,79,81,83,85,88,92,93,101,103,111,112,114,122,123,125,130,137$. 
Em 1936, RUDOLPH ${ }^{114}$ analisou radiografias periapicais de 439 pacientes tratados ortodonticamente, com idade de 7 a 21 anos e comparou as com as de um grupo controle de 739 pacientes não tratados, com idade de 7 a 79 anos. Os pacientes foram tratados com diferentes tipos de aparelho, como o arco vestibular com bandas, os planos de mordida fixos ou removíveis, bite blocks e splints. Ao final do primeiro ano de tratamento, $48,74 \%$ dos dentes radiografados apresentavam reabsorção e, na avaliação após 3 anos, a reabsorção estava presente em 74,63\% dos dentes. A reabsorção foi encontrada com mais freqüência no incisivo lateral superior e com menor freqüência nos pré molares inferiores. O maior número de casos de reabsorção ocorreu nos pacientes tratados durante ou após os 11 anos de idade. No grupo controle, formado por pacientes que nunca haviam realizado tratamento ortodôntico, 5,14\% dos dentes apresentaram reabsorção. O mais alto índice de reabsorção nesses pacientes ocorreu na faixa etária de 25 a 45 anos.

Em 1941, HEMLEY55 avaliou a incidência e o grau de reabsorção radicular decorrente do tratamento ortodôntico, por meio de radiografias periapicais realizadas antes do tratamento e após um ano, de 4.959 dentes de 195 pacientes, com idade média de 15,2 anos. A reabsorção foi classificada em leve, moderada, média e extrema e foi encontrada em 21,5\% dos 195 pacientes tratados. Nesses casos, 68,6\% dos dentes apresentaram reabsorção leve, 26,7\% reabsorção moderada, 4,7\% reabsorção média e nenhum caso apresentou reabsorção extrema. O tempo médio de tratamento dos casos que apresentaram reabsorção foi 2 anos e 8 meses. Segundo o autor, os dentes mais suscetíveis à reabsorção foram os incisivos centrais $(9,1 \%)$, seguidos dos laterais $(9,0 \%)$ e os dentes menos suscetíveis foram os segundos molares inferiores, os quais alcançaram um índice zero de reabsorção.

PHILLIPS ${ }^{101}$ em 1955, analisou radiografias cefalométricas e periapicais, pré e pós tratamento ortodôntico, de 131 
pacientes. Dois grupos de pacientes foram avaliados por dois métodos distintos. Sessenta e dois pacientes tratados com a técnica do Arco de Canto foram analisados por meio de radiografias cefalométricas laterais, dos quais 42 realizaram extração dos 4 primeiros pré molares, 2 foram tratados apenas com extração dos primeiros pré molares superiores e 18, sem extrações. Desses 62, 46 foram tratados na Universidade, sob a orientação de professores e 16, na clínica particular de um dos membros da equipe. Todos os casos da amostra apresentavam dentadura permanente, com idade variando de 10,7 a 18,5 anos. Nestes, o encurtamento radicular foi calculado pela diferença de comprimento do incisivo superior nas radiografias pós e pré -tratamento. Os outros 69 casos, analisados em radiografias periapicais, também foram tratados com a técnica do Arco de Canto, 54 na Universidade e 15 na clínica particular, sendo que em 43 casos foram extraídos os 4 pré molares, em 2 casos apenas os primeiros pré molares superiores foram extraídos, 3 casos extraíram outros dentes e 21 casos foram tratados sem extração. A reabsorção foi classificada, por meio de escores, em leve, moderada, excessiva e questionável. Dos 1.745 dentes examinados, 61\% não apresentaram perda radicular aparente, 26,8\% mostraram reabsorção moderada, 3\% reabsorção excessiva e 7,4\%, reabsorção questionável. Dos dentes reabsorvidos, $76,4 \%$ eram incisivos centrais superiores e inferiores, apresentando uma média de reabsorção de $2 \mathrm{~mm}$. A partir desses resultados, o autor concluiu que a incidência de perda apical, na maioria dos casos, pode ser atribuída às forças aplicadas pelo aparelho durante o tratamento, não existindo relação entre grau de reabsorção e sexo, idade ou tempo de tratamento. Os dentes traumatizados previamente, com coroas fraturadas ou deformidades radiculares apresentam maior suscetibilidade à reabsorção. Salientou, ainda, que alguns fatores metabólicos podem ser sugeridos como causadores de reabsorção, entretanto, o registro desses casos na literatura é insuficiente para validar tal afirmação. 
DESHIELDS ${ }^{42}$, em 1969, objetivando determinar se a freqüência e a gravidade de reabsorção radicular variam de acordo com a mecânica utilizada e com a quantidade de movimento dentário produzida no tratamento, avaliou os incisivos superiores, em radiografias cefalométricas laterais e periapicais, de 52 casos tratados com a técnica do Arco de Canto. Todos os casos analisados apresentavam as mesmas características, ou seja, Classe II, divisão 1, tratados sem extrações, com ausência de reabsorção no início do tratamento e em nenhum caso os incisivos centrais superiores tornaram se mais proeminentes em relação à linha sela násio, com o decorrer do tratamento. A idade dos pacientes variou de 12,38 a 14,18 anos e a média de tempo de tratamento foi de 21,57 meses. A reabsorção foi classificada por escores variando de $\mathrm{O}$ a 5 , de acordo com a intensidade. DESHIELDS ${ }^{42}$ não encontrou reabsorção em 5,77\% dos dentes, verificou reabsorção "possível” em 11,54\%, definida em 39,42\%, média em 37,98\%, moderada em 5,29\% e em nenhum caso observou reabsorção extrema. Não houve dimorfismo sexual. Segundo o autor, a reabsorção radicular apical ocorne em praticamente todos os dentes tratados ortodonticamente, por isso, o movimento de intrusão deve ser bem avaliado (já que é considerado o principal causador da reabsonção) e as forças ortodônticas devem ser cuidadosamente controladas para evitar danos aos dentes e tecidos adjacentes. Salientou ainda a necessidade das radiografias intrabucais fazerem parte da documentação ortodôntica.

Visando investigar se a reabsonção radicular decorrente do tratamento ortodôntico, evolui após a remoção das forças, VONDERAHE ${ }^{137}$, em 1973, examinou radiografias periapicais de 57 pacientes, de 8 a 41 anos, com idade média de 13 anos, tratados ortodonticamente por diferentes profissionais. A amostra foi constituída apenas de pacientes que apresentaram reabsorção radicular durante o tratamento. O período de pós-contenção variou entre 27 e 204 meses. A reabsonção foi classificada por escores, variando de 1 a 3, ou seja, leve, moderada e extrema. A relação entre a perda radicular apical e outras variáveis, como a idade, o tempo de tratamento, terapia com e sem extrações e tipo de má oclusão não foi significante. O autor 
afirmou que a reabsorção radicular, aparentemente iniciada com o tratamento ortodôntico, não progride quando o aparelho é removido e que os dentes reabsorvidos não apresentam sinais de mobilidade.

Um ano após, PLETS et al. ${ }^{103}$ realizaram uma pesquisa avaliando a média do comprimento radicular em pacientes tratados e não tratados ortodonticamente e as alterações no comprimento radicular ocorridas durante o tratamento. A amostra foi dividida em 3 grupos: um grupo controle, constituído por 50 pacientes, não tratados ortodonticamente, com idade média de 16 anos e 8 meses, os quais apresentavam incisivos centrais superiores intactos radiograficamente; o grupo 2, formado pela documentação inicial de 45 casos tratados ortodonticamente, com idade média de 12 anos e 8 meses e o grupo 3, formado pela documentação pós tratamento, dos mesmos casos descritos no grupo 2, agora com idade média de 15 anos e 10 meses. Todos os casos foram completamente bandados e o tempo médio de tratamento foi de 24,3 meses. As raízes, analisadas em radiografias cefalométricas laterais foram classificadas em normais, irregulares, anguladas e arredondadas ou planas, com escores variando de 1 a 4 . No grupo tratado ortodonticamente, $20 \%$ dos dentes não apresentaram reabsorção, enquanto que $31,11 \%$ mostraram reabsorção de grau 2, 15,55\%, reabsorção de grau 3 e 33,33\%, reabsorção de grau 4. Nenhum parâmetro biológico comum ou similaridade na mecânica foi encontrado nesses pacientes. Por isso, concluíram que não existe como determinar previamente a reabsorção radicular decorrente do tratamento ortodôntico. Ressaltaram, ainda, que a perda radicular de 1 ou 2 mm de estrutura pode ser insignificante quando não associada à perda óssea, porém, a combinação desses 2 fatores pode ser destrutiva à dentadura. Consideraram que o encurtamento radicular diagnosticado na radiografia pré tratamento pode ser resultado do fechamento precoce do ápice.

NEWMAN $^{92}$, em 1975, com o objetivo de estudar a relação da reabsorção radicular idiopática com as influências genéticas, causas 
sistêmicas, tipo de má oclusão, hiper e hipoparafunção oclusal, história médica e odontológica e com o tratamento ortodôntico, analisou radiografias periapicais, modelos, dados da anamnese, características genéticas, exames de sangue e os registros do exame clínico intrabucal de 47 jovens, apresentando reabsorção radicular em no mínimo 3 dentes, em ao menos 2 quadrantes diferentes. Os jovens pertenciam a 37 famílias diferentes, porém apenas 41 pacientes foram tratados ortodonticamente. A amostra foi obtida em diferentes lugares, incluindo os Estados Unidos, México e Canadá. A reabsorção foi classificada em ausente, questionável, definida e grave, em 1.100 dentes. Após a análise dos dados, o autor constatou que os dentes mais suscetíveis à reabsorção eram os incisivos centrais superiores, seguidos dos segundos pré molares superiores e inferiores e os menos suscetíveis eram os caninos inferiores. O mau posicionamento dentário, a mordida cruzada e os fatores genéticos não apresentaram relação com a reabsorção radicular, ao contrário da mordida aberta, que foi intimamente ligada a essa patologia. Segundo o autor, o tratamento ortodôntico aumenta a incidência e o grau de reabsorção radicular e apenas uma pequena relação foi encontrada entre o contato oclusal prematuro e o encurtamento radicular. Nenhuma relação genética definitiva foi determinada e os exames de sangue não apontaram problemas endócrinos ou metabólicos, principalmente o hipertiroidismo e o hipotiroidismo.

Analisando a documentação clínica e radiográfica de 60 pacientes de ambos os sexos, com idade média de 13 anos e 5 meses, tratados pela técnica do Arco de Canto, CANSANÇÃO ${ }^{35}$, em 1980, relacionou a reabsorção radicular conseqüente à terapia ortodôntica com o sexo, idade, duração do tratamento e período de uso do arco retangular e aparelho extrabucal. A reabsorção foi classificada por escores, variando de 0 a 3 , nas radiografias periapicais finais de cada paciente. O autor não encontrou reabsorção em $11,82 \%$ dos dentes examinados, verificou reabsorção suave em $55,47 \%$ dos dentes, reabsorção moderada em 30,39\% e reabsorção extrema em 
somente $2,10 \%$ dos dentes, sendo mais freqüente nos dentes superiores, principalmente nos incisivos. Para o autor, a suscetibilidade individual pode atuar como coadjuvante na gravidade da reabsorção, apesar dela ter se manifestado igualmente em ambos os sexos e não ter demonstrado relação com a idade. O período de utilização do arco retangular mostrou alguma influência na reabsorção, nos dentes inferiores; enquanto que, o arco extrabucal não atuou como agravante da reabsorção radicular nos primeiros molares superiores. Constatou, ainda, que a duração do tratamento interferiu na gravidade das reabsorções e ressaltou que o exame radiográfico é de vital importância no tratamento ortodôntico, para comprovar a presença de reabsorção radicular.

No ano seguinte, RÖNNERMAN; LARSSON112 examinaram radiografias periapicais dos incisivos superiores de 23 pacientes tratados com a técnica do Arco de Canto, antes, imediatamente após, três e 10 anos após o término do tratamento ativo. Os pacientes foram divididos em 4 grupos: o grupo A foi formado por 5 pacientes com má oclusão de Classe II, divisão 1, tratados com Ativador; o grupo B constituiu se de 9 pacientes, 8 Classe II, divisão 1 e um Classe II, divisão 2, tratados com 4 extrações; o grupo C foi formado por 5 pacientes Classe II, divisão 1, tratados com extrações apenas no arco superior e, finalmente, o grupo D, por 4 pacientes com má oclusão de Classe I e com apinhamento, tratados com extrações em ambos os arcos. A média de idade, ao início do tratamento, foi de 11 anos no grupo A e de 14,7 anos nos grupos B, C e D. A reabsorção foi classificada por escores, variando de 0 a 2 . Os autores encontraram reabsorção radicular apical nos incisivos superiores, na extensão de 1 a $3 \mathrm{~mm}$, em 39\% dos casos, indicando que radiografias de controle devem ser realizadas durante o tratamento ativo. A maior movimentação necessária para a correção da má oclusão nos grupos B e C pode ter sido responsável pela maior quantidade de reabsorção encontrada nestes, em relação ao grupo D, embora este grupo também tenha sido tratado 
com extrações. Não foram encontradas reabsorções apicais de mais de $3 \mathrm{~mm}$ e em $61 \%$ dos casos, nenhuma reabsorção ou reabsorção de menos de $1 \mathrm{~mm}$ foi observada. Além disso, foi encontrado apenas um risco mínimo de progressão da reabsorção radicular apical após o tratamento ativo ter sido completado.

MALMGREN et al. ${ }^{81}$, em 1982, compararam a freqüência e o grau de reabsorção radicular em incisivos traumatizados e não traumatizados, após o tratamento ortodôntico. De um total de 300 pacientes, vinte e sete foram selecionados, sendo 15 do sexo masculino e 12 do feminino, somando 55 incisivos traumatizados. A idade dos pacientes na época do traumatismo variou de 7 a 15 anos. Quatorze pacientes realizaram tratamento com aparelho fixo, 10, com associação de aparelho fixo e removível e apenas 3 pacientes trataram somente com aparelho removível (ativador). Os dentes traumatizados foram comparados com os dentes não traumatizados do mesmo paciente e, ainda, com um grupo controle, tratado ortodonticamente, com extrações de 4 pré molares e uso de aparelho fixo (33 com Arco do Canto e 22 com Begg). O grau de reabsorção foi classificado por escores, variando de 0 a 4. A reabsorção radicular esteve presente em $51 \%$ dos incisivos traumatizados, em $43 \%$ dos incisivos tratados com Arco de Canto e em 48\% daqueles tratados com a técnica de Begg. Os autores concluíram que os incisivos traumatizados, com reabsorção anterior ao tratamento, exibem mais reabsorção com o tratamento. Entretanto, os dentes com traumatismo leve ou moderado e ligamento periodontal intacto, após um período de observação de 4 ou 5 meses podem ser movidos com um prognóstico semelhante ao daqueles que não sofreram injúria.

ODENRICK; BRATTSTRÖM93 ${ }^{93}$ em 1983, com o objetivo de determinar a incidência de onicofagia na população e sua possível relação com a reabsorção radicular apical decorrente do tratamento ortodôntico, aplicaram um questionário a 340 jovens de ambos os sexos, com idade de 13 a 15 anos. A provável relação entre a onicofagia e a reabsorção radicular apical 
durante o tratamento ortodôntico, foi avaliada em radiografias periapicais de incisivos e caninos, em 2 grupos de pacientes tratados ortodonticamente com a técnica de Begg e do Arco de Canto. As raízes, analisadas por 2 examinadores, foram classificadas em 0 quando não havia reabsorção; 1 quando o contorno do ápice apresentava se irregular; 3 quando havia uma reabsorção de menos de $2 \mathrm{~mm} ; 5$ quando a reabsorção era de $2 \mathrm{~mm}$ a um terço de raiz e, finalmente, 7 para reabsorções de até dois terços de raiz. Um grupo foi constituído de 21 pacientes onicófagos tratados ortodonticamente e o outro, de 21 pacientes tratados ortodonticamente, os quais nunca haviam roído suas unhas. Todos os pacientes, em ambos os grupos, demonstraram alguma reabsorção após o tratamento, porém os autores encontraram um índice de reabsorção radicular significantemente mais alto nos pacientes onicófagos, previamente ao tratamento. Não foi encontrada correlação entre a reabsorção radicular e a quantidade de movimento dentário. Ao contrário, existiu uma correlação positiva entre reabsorção e tempo de tratamento. Como as reabsorções mais graves ocorreram nos pacientes onicófagos, seria sensato verificar a presença de onicofagia durante a anamnese e, deste modo, monitorizar radiograficamente os dentes anteriores de pacientes onicófagos graves, durante o tratamento ortodôntico.

No mesmo ano, LINGE; LINGE78 avaliaram a extensão e a incidência da reabsorção radicular apical de 719 pacientes tratados ortodonticamente, em radiografias periapicais, obtidas com a técnica do paralelismo, de 2.451 incisivos. A idade média no início do tratamento era de 12,8 anos e o tempo médio de observação foi de 3,6 anos, em ambos os sexos. Dos pacientes, $74 \%$ foram tratados com a técnica do Arco de Canto, $11 \%$ com aparelhos removíveis e 14\% com a combinação de ambos. O encurtamento radicular foi determinado pela diferença de comprimento dos dentes nas radiografias finais e iniciais. Segundo os autores, a reabsorção radicular apical que ocorre durante o tratamento ortodôntico é conseqüência de uma 
combinação complexa de biologia individual e efeito das forças mecânicas. LINGE; LINGE ${ }^{17}$ encontraram uma média de perda de comprimento, nos incisivos superiores, de 0,7 mm, tendo a maior perda ocorrido após os 11 anos. Não encontraram relação entre o sexo, trespasse horizontal ou vertical, hábitos e tempo de tratamento, com as alterações no comprimento radicular ocorridas durante o tratamento. Correlacionando a reabsorção radicular apical com história prévia de trauma, uso de aparelhos fixos, correção de caninos superiores impactados, aparelhos fixos, elásticos de Classe II e fios retangulares, verificaram que esses itens influenciam decisivamente no grau de reabsorção. Os caninos bem posicionados, assim como pacientes que realizaram o tratamento ortodôntico precocemente (antes dos 11 anos), muito raramente mostraram sinais radiográficos de reabsorção radicular. Sinais precoces de reabsorção podem agravar a situação clínica, por isso os autores sugerem a realização de um controle radiográfico periódico durante o tratamento.

ARNESEN $^{15}$, em 1984, propos se a analisar e estudar, por meio de radiografias periapicais e cefalométricas laterais, a freqüência e o grau de reabsorção radicular em pacientes submetidos ao tratamento ortodôntico, relacionando a com o sexo, idade, tempo de tratamento e tipos de movimento (movimentos de inclinação, deslocamento ântero posterior e de corpo). A amostra constituiu se de 50 jovens, com idade entre 9 e 16 anos, obedecendo os seguintes critérios: todos os casos foram tratados com a técnica do Arco de Canto, não apresentavam reabsorção antes do tratamento e apresentavam reabsorção em pelo menos um dente, ao final do tratamento. Após a análise das radiografias pós tratamento e a classificação da reabsorção por escores, constatou a ocorrência de reabsorção radicular em diferentes graus, nos pacientes tratados ortodonticamente, sem nenhuma prevalência entre os arcos. Entre os grupos dentários, a maior prevalência foi dos incisivos, principalmente os superiores. Não observou dimorfismo sexual, porém, o 
incremento de reabsorção foi diretamente proporcional ao aumento da faixa etária e não verificou uma relação direta entre a duração do tratamento e o tipo de movimento com a quantidade de reabsorção radicular. O autor sugeriu que a predisposição individual atua como principal fator para o desenvolvimento da reabsorção radicular.

Em 1986, COPELAND; GREEN ${ }^{38}$ questionaram se a reabsorção radicular apical continua após o tratamento ativo ter sido completado. Analisaram a perda de comprimento radicular por meio de radiografias cefalométricas laterais, realizadas antes, após o tratamento e após o período de contenção, que variou de 9 meses a 6 anos e 2 meses. Quarenta e cinco pacientes, com média de idade de 13 anos e 1 mês, ao início do tratamento, todos tratados pela técnica do Arco de Canto, em média, por 2 anos e 10 meses, cujos dentes apresentavam ao menos 1 milímetro de reabsorção nas radiografias finais, fizeram parte da amostra. A média de reabsorção radicular apical ocorrida durante o tratamento ativo foi de 2,93 $\mathrm{mm}$ e após o tratamento ativo foi de 0,1 $\mathrm{mm}$. Os autores constataram que a reabsorção radicular apical continua somente durante um pequeno período após o tratamento ativo (5 a 6 semanas). Terminado este período, o cemento reparador é depositado nas superfícies radiculares afetadas. Para os autores, se não há reabsorção radicular apical nos incisivos superiores ou inferiores, raramente esta será encontrada em outros dentes, porque os dentes anteriores são os mais freqüentemente afetados e se a reabsorção for diagnosticada durante o tratamento, os objetivos do tratamento devem ser reavaliados.

Ainda em 1986, DERMAUT; DE MUNCK ${ }^{41}$ avaliaram, por meio de radiografias periapicais, a relação entre a intrusão e a reabsorção dos dentes ântero superiores. O grupo experimental foi formado por 20 pacientes, com idade média de 15 anos, nos quais 66 incisivos (35 centrais e 31 laterais) foram intruídos, em média 3,6 $\mathrm{mm}$, em um período médio de 29 semanas. O grupo controle foi formado por 15 indivíduos, com idade média 
de 22 anos, sem tratamento ortodôntico prévio, nos quais o encurtamento radicular foi medido em 58 incisivos. Os autores não encontraram relação entre a duração da mecânica de intrusão e a quantidade de reabsorção, assim como não foi encontrada diferença na quantidade de reabsorção entre incisivos centrais e laterais. A média de reabsorção encontrada nos grupos experimentais foi de 2,5 mm. DERMAUT; DE MUNCK ${ }^{41}$, comparando os seus resultados com os encontrados anteriormente por LINGE; LINGE78, afirmaram que a intrusão é o movimento que mais causa reabsorção durante o tratamento ortodôntico, comparado a outras variáveis do tratamento como torque, elásticos de Classe II e fios retangulares..

Para esclarecer se o movimento dentário ortodôntico em pré molares autotransplantados afeta o comprimento radicular final, LAGERSTRÖM; KRISTERSON73, também em 1986, realizaram um estudo em 59 pré molares autotransplantados. A amostra foi dividida em 3 grupos: um grupo ortodôntico, formado por 29 pré molares autotransplantados, de pacientes com idade média de 12,7 anos, expostos a no mínimo 12 meses de movimentação ortodôntica com a técnica do Arco de Canto; um grupo controle, formado por 30 pré molares autotransplantados, de pacientes com idade média de 12,3 anos, não expostos ao tratamento ortodôntico e em ambos os grupos, os pré molares contralaterais serviram de controle. Os autores mediram a reabsorção radicular em radiografias periapicais realizadas imediatamente após o autotransplante e após o tratamento ortodôntico e a completa formação radicular. Encontraram uma pequena diferença, não significante, no comprimento radicular final, entre o grupo autotransplantado tratado e o autotransplantado controle. A diferença no comprimento radicular final, entre os pré molares autotransplantados e os dentes controles contralaterais, foi maior no grupo autotransplantado ortodôntico do que no grupo autotransplantado controle. 
Com a proposta de verificar a relação da recidiva pós tratamento ortodôntico com a integridade da crista óssea e a reabsorção radicular, SHARPE et al. ${ }^{122}$, em 1987, examinaram as radiografias periapicais pré, pós tratamento e após 10 anos, de 36 pacientes que tinham completado a fase de contenção há 10 anos. Os pacientes foram divididos em 2 grupos. Dezoito pacientes com recidiva do apinhamento inferior de $2 \mathrm{~mm}$ ou mais, formaram o grupo de estudo, no qual 323 raízes foram examinadas. O grupo controle foi formado por 18 pacientes, sem recidiva do apinhamento inferior, nos quais 324 raízes foram examinadas. No grupo estudo, a média de idade, ao início do tratamento, foi de 11,3 anos e o tratamento durou, em média, 43,3 meses. No grupo controle, a média de idade, ao início do tratamento, foi de 12,7 anos e o tratamento levou, em média, 31,5 meses para ser concluído. As radiografias periapicais dos incisivos centrais, caninos, primeiros molares superiores e inferiores foram avaliadas e a reabsorção foi classificada por escores, variando de 0 a 3 . Os incisivos centrais superiores mostraram a maior quantidade de reabsorção, seguidos pelos primeiros molares e por último, pelos caninos. A raiz distal dos molares inferiores e a raiz distovestibular dos primeiros molares superiores mostraram mais reabsorção do que a mesial, porém, não foi observada reabsorção na raiz lingual dos molares superiores. $\mathrm{Na}$ maxila, no grupo estudo (com recidiva), os autores encontraram mais reabsorção radicular, enquanto que na mandíbula, a quantidade de reabsorção foi similar nos 2 grupos. O trabalho sugere que existe uma relação entre a perda de suporte periodontal, a perda radicular e a recidiva ortodôntica.

LEVANDER; MALMGREN ${ }^{76}$, em 1988, objetivando testar se é possível estimar o risco de reabsorção radicular grave nos estágios precoces do tratamento ortodôntico e avaliar a importância da forma radicular na reabsorção radicular, realizaram um estudo com 98 pacientes, com idade média de 15 anos. Os pacientes apresentavam 3 diferentes tipos de má oclusão: 44 com Classe I, 52, Classe II e 2, Classe III. Setenta e dois pacientes 
foram tratados com extração e 26, sem extração. A metade dos pacientes foi tratada com a técnica de Begg e a outra, com a técnica do Arco de Canto, por uma média de tempo de tratamento de 19,5 meses. O exame radiográfico foi realizado em 390 dentes, avaliados antes, após 6 a 9 meses do início e ao final do tratamento. A reabsorção foi classificada em ausente, leve, moderada, acentuada e extrema, enquanto que a forma das raízes recebeu a seguinte classificação: normal, encurtada, achatada, dilacerada e em forma de pipeta. A reabsorção foi relacionada com a idade, o sexo, a forma radicular, o tempo de tratamento com arco retangular, com os torque auxiliares, com as molas de verticalização, com os elásticos de Classe II e o tempo total de tratamento. $\mathrm{Na}$ avaliação radiográfica após 6 a 9 meses, duzentos e cinqüenta e seis dentes (66\%) não apresentaram reabsorção ou apresentaram somente contorno irregular, cento e vinte e nove dentes (33\%) apresentaram reabsorção leve e 5 dentes (1\%), reabsorção acentuada. Ao final do tratamento, 131 dentes (34\%) não apresentaram reabsorção, ou apresentaram apenas contorno irregular, 188 (48\%) apresentaram reabsorção leve, 66 (17\%), acentuada e 5 dentes (1\%), reabsorção extrema. O grau de reabsorção radicular nos dentes com forma de pipeta foi significantemente maior do que nos dentes com forma radicular normal. A reabsorção acentuada foi mais freqüente no sexo feminino (23\%) do que no masculino (16\%). As demais variáveis estudadas, inclusive o tipo de técnica utilizada, não mostraram relação significante com a reabsorção radicular. Concluíram que as raízes com forma de pipeta apresentam risco acentuado à reabsorção, enquanto que as raízes arredondadas apresentam risco moderado. Além disso, verificaram que a reabsorção acentuada, na avaliação dos 6 a 9 meses, indica um maior risco de reabsorção extrema, enquanto que a reabsorção moderada indica um risco moderado ao final do tratamento e que quando há apenas um contorno irregular o risco de reabsorção extrema ao final do tratamento é pequeno. 
REMINGTON et al. ${ }^{111}$, em 1989, com a proposta de avaliar o estágio dos dentes que haviam sofrido reabsorção durante o tratamento ativo e determinar se o processo de reabsorção é progressivo ou se estabiliza se após a remoção do aparelho, analisaram radiografias periapicais de 100 pacientes tratados ortodonticamente, na Universidade e em diversas clínicas particulares. Os pacientes, com 13,6 anos, em média, ao início do tratamento, foram tratados por um tempo médio de 2,2 anos e a média de tempo da remoção do aparelho, até o exame, foi de 14,1 anos. A reabsorção foi classificada por escores, variando de 0 a 4 . Os autores encontraram $52 \%$ dos dentes com contorno apical normal ou com irregularidade apical e com o mesmo comprimento do início do tratamento, $40 \%$ com reabsorção radicular moderada, $7 \%$ com reabsorção radicular apical acentuada e apenas $1 \%$ com reabsorção extrema. Três dentes tratados endodonticamente apresentaram menos reabsorção do que o dente contralateral. Os autores constataram que os dentes superiores foram reabsorvidos com mais gravidade e maior freqüência que os inferiores; a mobilidade foi rara (ocorreu em apenas 2 pacientes), no entanto, o efeito combinado da reabsorção radicular apical e da perda da crista óssea no ligamento periodontal não foi avaliado; a remodelação progressiva das superfícies radiculares foi evidente, mas não houve restabelecimento do contorno radicular e do comprimento original do dente no período da avaliação. Constataram ainda, que apenas poucos casos mostraram graus extremos de encurtamento radicular durante o tratamento e, finalmente, que a reabsorção radicular apical que ocorre durante o tratamento ativo não progride após a remoção da força.

Ainda em 1989, GOLDIN ${ }^{49}$ propos se a investigar o tratamento da retrusão da maxila por meio do desenvolvimento nasomaxilar promovido pelo torque radicular vestibular. Quantificou as alterações no ponto A, em magnitude e direção e quantificou também a reabsorção radicular resultante da interação da raiz com a lâmina cortical densa. Os pacientes 
foram tratados com a técnica do Arco de Canto, alguns na Universidade e outros em clínica particular. O comprimento radicular foi medido em radiografias cefalométricas laterais de 34 pacientes com idade de 8 a 15,7 anos. Dezessete desses pacientes, tratados ortodonticamente por um período de 0,31 a 3,7 anos, constituíram o grupo experimental, tendo sido radiografados antes, em vários estágios do tratamento e após o período de contenção. O grupo controle foi constituído de 17 pacientes, não tratados ortodonticamente, radiografados da infância à adolescência, em intervalos anuais. A reabsorção radicular ocorreu em uma média constante de $13 \%$ ao ano, nos pacientes tratados. Dois fatores mostraram relação com a reabsorção: a quantidade de torque aplicada e a quantidade de movimento dentário realizado. Nesta pesquisa, não houve dimorfismo sexual e a idade dos pacientes não apresentou relação com a quantidade de perda radicular apical. GOLDIN ${ }^{49}$ declarou que a reabsorção radicular apical constitui uma conseqüência inevitável do tratamento ortodôntico.

MCFADEN ${ }^{85}$, no mesmo ano, justificou o maior interesse do estudo radiográfico da reabsorção radicular apical, afirmando que esta é mais perceptível radiograficamente do que a reabsorção radicular vestibular ou lingual. Além disso, a área apical recebe uma grande concentração de esforços e é a superfície que enfrenta a direção do movimento fisiológico durante a extrusão. Este estudo examinou a relação entre a intrusão dos incisivos superiores e inferiores e o encurtamento radicular. Objetivou, ainda, relacionar o encurtamento radicular e a intrusão com a idade, o sexo, o tratamento com ou sem extrações, o tipo facial, o tempo de tratamento, a angulação dos incisivos em relação aos planos esqueléticos e a largura da sínfise. Foram avaliados os cefalogramas e as radiografias periapicais de 38 pacientes tratados ortodonticamente, com idade média de 13,1 anos. O tempo médio de tratamento foi de 28,8 meses. Vinte e quatro pacientes foram tratados sem extrações e 14, com extrações. Três deles apresentavam má 
oclusão de Classe I, trinta, de Classe II, divisão 1 e 5, Classe II, divisão 2. A média de encurtamento encontrada nos incisivos superiores foi de 1,84 $\mathrm{mm}$ e nos inferiores, 0,61 mm. Não houve relação entre a reabsorção radicular apical e a largura da sínfise, a idade, o sexo, o tipo facial, a terapia com extrações e a quantidade de intrusão nos dentes inferiores. Houve, sim, uma relação positiva entre reabsorção e tempo de tratamento, assim como uma pequena relação com a quantidade de intrusão dos incisivos superiores. MCFADEN851 ressaltou a importância do controle do tempo de tratamento, principalmente quando a intrusão dos incisivos superiores é realizada. De acordo com o autor, há pessoas com alto risco para o encurtamento radicular, em ambos os arcos, as quais podem requerer uma monitorização mais cuidadosa durante o movimento de intrusão.

As alterações na redução do comprimento radicular, bem como na altura das cristas ósseas alveolares, decorrentes do tratamento ortodôntico em pacientes adultos e adolescentes, foram avaliadas por HARRIS; BACKER $^{52}$, em 1990. Os 59 pacientes selecionados (29 adolescentes e 30 adultos), com idade média de 12,5 e 27,9 anos, respectivamente, foram tratados por um período médio de 2,5 anos, com a "Técnica das Forças Direcionais" e com extração de quatro pré molares. A reabsorção foi determinada por dois métodos complementares: primeiramente, foi classificada por escores, de acordo com o método proposto, em 1988, por LEVANDER; MALMGREN ${ }^{76}$. Além disso, os comprimentos radiculares foram medidos com um paquímetro, em radiografias panorâmicas e cefalométricas laterais realizadas antes e após o tratamento ortodôntico. A avaliação radiográfica pré tratamento mostrou diferenças substanciais entre os pacientes adolescentes e os adultos, sendo que estes apresentavam redução significante tanto do comprimento radicular, quanto da altura da crista alveolar. Após o tratamento, os dois grupos apresentaram alterações muito semelhantes, ambos evidenciando uma redução média de 1,0 a 1,5 mm de comprimento radicular 
(as taxas mais elevadas foram observadas nos incisivos superiores). Ao término do tratamento, 58\% dos pacientes adolescentes e $61 \%$ dos pacientes adultos evidenciaram algum grau de reabsorção Os autores constataram que, apesar da idade ser freqüentemente sugerida como fator predisponente da reabsorção radicular e óssea, ela, isoladamente, desassociada dos quadros que normalmente a acompanham, como problemas de articulação temporomandibular e um maior índice de doença periodontal, não predispõe a uma perda dos tecidos de suporte dentário significantemente maior.

Visando determinar se os incisivos vitais e os tratados endodonticamente exibem uma suscetibilidade semelhante à reabsorção radicular apical, em reposta ao tratamento ortodôntico, SPURRIER et al. ${ }^{125}$, em 1990, de uma amostra de 12.000 pacientes, selecionaram 43 com um lado tratado endodonticamente e o outro com incisivos vitais e analisaram suas radiografias periapicais pré e pós tratamento. Os pacientes foram avaliados após receberem, no mínimo, um ano de tratamento ativo. As radiografias foram projetadas por um projetor de eslaides ajustado para produzir uma magnificação de 10 vezes e uma régua transparente foi utilizada para medir as imagens diretamente na tela, determinando assim, a diferença entre o comprimento radicular inicial. Sessenta e sete por cento (67\%) dos pacientes apresentaram reabsorção maior de seus dentes controle (vitais) do que seus contralaterais tratados endodonticamente. Apenas 33\% dos dentes tratados endodonticamente reabsorveram em grande extensão. Os resultados desta pesquisa indicam que há uma diferença clínica muito pequena na quantidade de reabsorção radicular apical entre dentes vitais e não vitais, embora, em nível estatístico, os incisivos tratados endodonticamente tenham mostrado menor potencial de risco à reabsorção radicular apical, sugerindo que os ortodontistas não necessitam de maiores preocupações ao movimentarem esses dentes. Nenhuma diferença significante na reabsorção radicular entre pacientes do sexo masculino e feminino foi notada nos incisivos tratados 
endodonticamente, enquanto que os dentes vitais apresentaram reabsorção mais significante nos pacientes do sexo masculino. Os autores recomendam especial atenção, antes da movimentação de um dente, às condições do seu tratamento endodôntico.

KALEY; PHILLIPS65, em 1991, objetivando estudar casos tratados com a técnica do Arco de Canto, determinando a prevalência da reabsorção externa e estimando o risco de reabsorção extrema, associada às características prévias e às do tratamento, examinaram as radiografias panorâmicas pré e pós tratamento de 200 pacientes da clínica particular de um dos autores. Os pacientes apresentavam idade média de 16,6 anos (variando de 11 a 48 anos) ao início do tratamento e foram tratados por um período médio de 34 meses (variando de 18 a 64 meses). Somente os incisivos centrais e os laterais superiores, os incisivos centrais inferiores e os segundos pré molares superiores e inferiores foram examinados. A reabsorção radicular, analisada em radiografias panorâmicas, foi classificada por escores, variando de $\mathrm{O}$ a 3 . As radiografias cefalométricas pré e pós tratamento foram utilizadas apenas para verificar a quantidade e a direção do movimento dentário. Os resultados confirmaram afirmações anteriores de que os incisivos superiores são os dentes mais reabsorvidos durante o tratamento. Noventa por cento (90\%) dos incisivos centrais superiores e apenas 50\% dos pré molares superiores e inferiores foram reabsorvidos. A reabsorção extrema foi diagnosticada em 3\% dos dentes, porém, somente 1\% dos pacientes apresentou esse grau de reabsorção. Correlacionando a reabsorção encontrada com as características pré tratamento, observaram que os dentes dos pacientes com má oclusão de Classe I foram significantemente menos reabsorvidos do que os dos pacientes com Classes II e III. Isto provavelmente reflete a menor quantidade de movimento dentário, particularmente de incisivos superiores, necessária para a correção desse tipo de má oclusão. Os pacientes com má 
oclusão de Classe III apresentaram maior quantidade de reabsorção. A quantidade de intrusão e extrusão realizada não foi considerada um fator significantemente correlacionado à reabsorção.

Procurando determinar uma relação entre as características pré tratamento e as variáveis do tratamento com a reabsorção radicular apical decorrente do tratamento ortodôntico em incisivos superiores, LINGE; LINGE79, no mesmo ano, utilizaram as radiografias periapicais, obtidas pela técnica do paralelismo, de 485 pacientes, sendo 288 do sexo feminino e 197 do masculino, com idade variando de 11,5 a 25 anos. Analisaram, ainda, a história prévia de traumatismo na maxila, a persistência de hábitos de sucção após os 7 anos de idade, as alterações da língua em repouso, na fala e na deglutição, o trespasse horizontal e a correção de caninos superiores impactados. Os pacientes foram tratados em uma clínica particular por dois ortodontistas diferentes. Das variáveis do tratamento, foram analisados o tempo de uso do arco retangular, o tempo de uso de elásticos de Classe II e o tempo total de tratamento. As modalidades de tratamento utilizadas foram Arco de Canto com fio de 0,018 polegada, exclusivamente em 60,2\% dos casos, somente aparelhos removíveis em 9,1\%, combinação de aparelhos fixos e removíveis em $28,5 \%$ dos casos e aparelhos fixos sem bandagem dos incisivos em 2,3\% dos casos. Encontraram uma média de $0,9 \mathrm{~mm}$ de reabsorção nos incisivos superiores e um encurtamento de mais de $2,5 \mathrm{~mm}$ (significante do ponto de vista clínico), em um ou mais incisivos, foi encontrado em $16,5 \%$ dos pacientes. O fator mais fortemente correlacionado com a reabsorção radicular foi a presença de traumatismo, enquanto que a correção ortodôntica de caninos superiores impactados foi considerada apenas uma situação de risco. O trespasse horizontal, o uso de elásticos de Classe II, o tempo de uso do arco retangular e ainda a postura inadequada da língua foram positivamente relacionados com a reabsorção radicular, ao contrário do uso de aparelhos removíveis, os quais não foram considerados fatores de risco. Os autores 
concluíram que há necessidade de um controle radiográfico rotineiro (com radiografias padronizadas) durante o tratamento ortodôntico e que as variações anatômicas, fisiológicas e genéticas podem ser responsáveis pelas variações nas respostas teciduais.

HARRIS; BUTLER ${ }^{53}$, em 1992, acreditavam que a reabsorção radicular apical externa era uma conseqüência comum da mecanoterapia ortodôntica, podendo ocorrer, no entanto, por muitas outras causas, além do movimento dentário. Afirmaram que a aspereza radicular progressiva constitui uma função normal do envelhecimento, provavelmente em resposta ao uso cumulativo, à agressão das forças mastigatórias e a outras funções bucais no periodonto. Explicaram que o processo que conduz à mordida aberta anterior envolve pressão da língua nos dentes anteriores, excedendo os limites fisiológicos, fazendo com que os cementoclastos invadam a região traumatizada, resultando em reabsorção periapical. Por este motivo, propuseram se a avaliar a forma radicular de incisivos centrais superiores permanentes em pacientes com mordida aberta anterior, comparando os com uma série de pacientes com mordida profunda. Sessenta e três casos, sendo 32 com mordida aberta e 31 com mordida profunda, com idade variando de 10 a 32 anos, foram avaliados por 2 métodos complementares. Em radiografias periapicais, a reabsorção foi classificada por escores, de acordo com o método proposto anteriormente por LEVANDER; MALMGREN ${ }^{76}$. O encurtamento radicular foi determinado, quantitativamente, pela diferença de comprimento do incisivo central superior, encontrada entre a radiografia pós e pré tratamento, nas radiografias cefalométricas laterais. Os pacientes com mordida aberta exibiram um alto grau de reabsorção, já nas radiografias pré tratamento. Os autores verificaram que o grau de inclinação para vestibular e a quantidade de verticalização necessária para a correção da má oclusão não foram relevantes em relação à reabsorção. Nas radiografias pós tratamento, o grupo com mordida aberta continuou apresentando mais reabsorção, 
confirmando que as forças intrusivas e de torque, promovidas pela língua nos incisivos, são capazes de produzir a reabsorção apical. Em resumo, a reabsorção patológica ocorre quando as forças nos dentes excedem a resistência e a capacidade reparativa dos tecidos. Além disso, quanto mais grave a má oclusão, maior a quantidade de reabsorção esperada. Os resultados também indicam que o tratamento ortodôntico, por si só, não é o maior contribuinte para a reabsorção nos pacientes com mordida aberta, por isso melhoras estéticas e funcionais justificam os riscos.

Com o intuito de avaliar o grau de reabsorção radicular induzido pela mecanoterapia ortodôntica, SILVA FILHO et al. ${ }^{123}$, em 1993, utilizaram as radiografias periapicais pós tratamento de 50 pacientes, trinta do sexo feminino e 20 do sexo masculino, com idade média de 14 anos e 2 meses e 14 anos e 3 meses, respectivamente, tratados com as técnicas do Arco de Canto (40 casos) e Arco Reto (10 casos), por um tempo médio de 2 anos e 3 meses. As radiografias foram analisadas por 3 examinadores distintos e a reabsorção foi classificada em grau 0 , quando ausente; grau 1 quando havia apenas um arredondamento do ápice e grau 2, quando a reabsorção era evidente. SILVA FILHO et al. ${ }^{63}$ encontraram reabsorção radicular em 100\% dos casos examinados, em grau semelhante para ambos os sexos. Porém, geralmente suave, não inviabilizando o tratamento. Dessa forma, esses autores, concordam com outros que acreditam que os riscos justificam os benefícios obtidos com o tratamento.

No ano seguinte, HENDRIX et al. ${ }^{56}$ propuseram se a determinar a extensão da reabsorção radicular apical, após a terapia com aparelho fixo nos dentes posteriores e a avaliar se os fatores predisponentes podem ser determinados previamente. Verificaram, ainda, a relação entre a reabsorção radicular encontrada e o sexo, a idade, o estágio de formação das raízes, o tipo de tratamento realizado (com ou sem extrações) e a duração do tratamento. O comprimento radicular foi medido em radiografias 
panorâmicas de 153 pacientes tratados com a técnica do Arco de Canto, divididos em 2 grupos, de acordo com o estágio de formação radicular. O grupo A foi formado por pacientes com raízes incompletas, ao início do tratamento (com exceção dos primeiros molares) e o grupo B foi formado por pacientes com raízes completas, com exceção dos segundos e terceiros molares. Os comprimentos dentários finais dos grupos A e B foram comparados com os comprimentos dentários iniciais do grupo B. O grupo A, após o tratamento, não mostrou diferenças significantes com a média de comprimento do grupo B ao início do tratamento. As diferenças na média de comprimento radicular pré e pós tratamento no grupo B foram significantes. Os autores constataram que os dentes posteriores mostraram encurtamento durante o tratamento ortodôntico ativo, independentemente do sexo, idade, duração ou tipo de tratamento (com ou sem extrações). Verificaram que os dentes com raízes incompletas, ao início do tratamento, mostraram encurtamento radicular durante o tratamento ativo, embora este tenha sido menor do que aquele que ocorreu no grupo com raízes completas.

Para avaliar a qualidade dos tratamentos ortodônticos realizados no Departamento de Ortodontia, da Universidade de Lund, em Malmo, em um período de 10 anos, AHLGREN ${ }^{1}$, em 1993, examinou os registros radiográficos de 480 pacientes tratados na clínica de pós graduação. Cinqüenta por cento dos casos foram tratados com aparelhos fixos e o restante, com aparelhos removíveis. A reabsorção foi diagnosticada por meio de radiografias periapicais e panorâmicas e as alterações radiculares com menos de $1 \mathrm{~mm}$ não foram consideradas. A reabsorção radicular foi encontrada em praticamente todos os casos tratados com aparelhos fixos, enquanto que nos casos tratados com aparelhos removíveis, nenhum tipo de reabsorção foi encontrado. O tamanho do encurtamento foi pequeno (1 a $3 \mathrm{~mm}$ ), nunca excedendo a um terço do comprimento radicular, sendo que os incisivos superiores foram os dentes mais vulneráveis. 
MARTINS; CANSANÇÃO; SANCHEZ ${ }^{83}$, em 1994, avaliaram se, posteriormente à remoção dos aparelhos, a reabsorção radicular consecutiva à terapia ortodôntica progride ou não. Para tal, analisaram as radiografias periapicais após o tratamento e após 5 anos, de 39 pacientes, 31 do sexo feminino e 8 do sexo masculino, todos tratados com a técnica do Arco de Canto. As radiografias foram comparadas e a reabsorção, classificada por escores. Foram examinados 556 dentes, dos quais, 71,40\% não apresentaram alteração e 28,41\% mostraram aumento na quantidade de reabsorção. Destes 28,41\%, 25,71\% apresentaram aumento de 2 escores e aumento de apenas um escore ocorreu em $2,69 \%$ dos casos. Os autores concluíram que a reabsorção radicular pós tratamento ortodôntico não compromete a estabilidade dos dentes, cessando com a remoção do aparelho, na maioria dos casos observados. Quando a reabsorção apresenta alguma progressão, esta não é contínua, pois ocorre apenas uma remodelação apical.

LEVANDER; MALMGREN; ELIASSON77, no mesmo ano, avaliaram o efeito da interrupção temporária na mecanoterapia, em dentes nos quais a reabsorção radicular foi diagnosticada após um período inicial de 6 meses de tratamento com aparelho fixo. Foram analisadas as radiografias de 40 pacientes que apresentavam reabsorção radicular de mais de $2 \mathrm{~mm}$. Destes, quinze eram do sexo masculino e 25 do sexo feminino, todos tratados com a técnica do Arco Reto, sendo que 28 deles foram tratados com extrações. Os pacientes foram divididos em 2 grupos de 20. No grupo 1, a mecânica transcorreu normalmente, enquanto que no grupo 2 houve uma interrupção por 2 meses. O tratamento ativo durou de 12 a 32 meses (21, em média) no grupo 1 e de 10 a 31 meses (20, em média) no grupo 2. Todos os pacientes foram radiografados com posicionadores confeccionados individualmente e exibiram reabsorção apical pronunciada após o período inicial de 6 meses de tratamento. Houve uma diferença significante na magnitude de reabsorção encontrada no grupo $1(1,5 \mathrm{~mm})$ e no grupo $2(0,4 \mathrm{~mm})$. De acordo com os 
autores, a interrupção das forças facilita a reorganização do tecido periodontal lesado e reduz o encurtamento radicular. Verificaram que as variáveis da anamnese e do tratamento (Classificação de Angle, trauma, tratamento com ou sem extrações, tempo com o arco retangular, tempo com elásticos de Classe II e tempo total de tratamento) não foram intimamente relacionadas às diferenças na magnitude da reabsorção radicular. Ressaltaram a importância dos registros das alterações apicais durante o tratamento ortodôntico, pois a descoberta precoce de reabsorção radicular suave indica um risco futuro de mais reabsorção no decorrer da terapia. No entanto, a interrupção temporária do tratamento, empregando arcos passivos durante 2 ou 3 meses, pode reduzir o risco de reabsorções acentuadas.

Com o objetivo de testar as diferenças quanto ao risco de reabsorção em 2 técnicas diferentes, Arco de Canto e de Begg, e de verificar a relação de outros fatores, como o tempo de tratamento, a idade e as relações dentoesqueléticas, com o risco de reabsorção, BECK; HARRIS ${ }^{20}$, em 1994, avaliaram radiograficamente os dentes de 83 jovens com má oclusão de Classe I, dos quais 50\% foram tratados com a técnica de Tweed e os 50\% restantes, com a técnica de Begg. Todos os pacientes foram tratados com extrações dos primeiros pré molares, em um período de 1 a 6 anos. A reabsorção foi avaliada ao início e ao final do tratamento ativo, por dois métodos complementares. O grau de reabsorção foi avaliado em radiografias periapicais e os comprimentos radiculares, medidos em radiografias panorâmicas e cefalométricas laterais. Foram medidas as raízes dos incisivos centrais superiores e inferiores, segundos pré molares inferiores e primeiros molares superiores e inferiores. A freqüência de reabsorção no incisivo lateral superior esquerdo foi mais alta na técnica de Tweed. Os dados encontrados indicam que muitos fatores como, idade, tempo de tratamento e técnica utilizada podem ser descartados como indutores de maior risco de reabsorção radicular apical. Talvez a natureza da má oclusão determine um maior ou 
menor risco de reabsorção radicular, já que más oclusões graves necessitam de grande quantidade de movimentação e conseqüentemente o risco de reabsorção é maior. Testando a quantidade de alterações no tratamento, descobriram uma associação significante: quanto maior a correção do trespasse horizontal, maior a perda de comprimento radicular na raiz mesial do primeiro molar superior. A freqüência de reabsorção externa, após o tratamento, foi, em média, 62\% para os incisivos centrais superiores, diminuindo progressivamente nos laterais, segundos pré molares superiores e inferiores, caindo para $5 \%$ na raiz distal do primeiro molar inferior, tanto nos casos tratados com Tweed, como nos tratados com Begg. Independentemente da técnica utilizada, as mecânicas intrusivas aumentaram o risco de reabsorção radicular, conseqüência óbvia da forma da raiz. Felizmente, removendo o agente agressor, processos reparativos são realizados e a fagocitose da dentina é interrompida (exceto nas margens agudas). Os autores concluíram que, apesar de promoverem a reabsorção por meios diferentes, as técnicas de Tweed e Begg provocam o mesmo risco de reabsorção, independentemente de sexo, idade ou tempo de tratamento. Além disso, quanto maior a correção realizada, maior o risco de reabsorção.

BLAKE; WOODSIDE; PHAROAH ${ }^{24}$, em 1995, avaliaram a diferença de reabsorção radicular apical provocada nos dentes od spacientes que utilizaram bráquetes da técnica do Arco de Canto e de SPEED. Por fornecer ação de torque e rotação contínuos, sugeriu se que uma maior reabsorção radicular apical deveria ser esperada quando os bráquetes SPEED fossem comparados aos bráquetes convencionais. Radiografias periapicais pré e pós tratamento de 63 pacientes, 30 tratados com SPEED e 33 com Arco de Canto pré ajustado foram estudadas. Reabsorções radiculares mais significativas foram encontradas em 12,54 \% dos incisivos laterais superiores e em 8,04 \% dos incisivos centrais superiores, confirmando a maior incidência de reabsorção radicular nos dentes superiores, em comparação com os 
inferiores. Essa maior reabsorção, observada nos incisivos laterais superiores, pode ser explicada pelo posicionamento das alças para fechamento dos espaços, em casos com extrações, muito próximas a esses dentes. Não foi encontrada diferença significante na reabsorção radicular apical após o tratamento com os bráquetes pré ajustados da técnica do Arco de Canto e SPEED.

MIRABELLA; ARTUN88, em 1995, objetivando identificar os fatores de risco para a reabsorção radicular apical em adultos tratados ortodonticamente e analisando principalmente raízes com forma atípica, o comprimento radicular, a quantidade de movimento radicular e o tipo de tratamento realizado, examinaram as radiografias periapicais e cefalométricas laterais, pré e pós tratamento, de 500 pacientes adultos. Os pacientes com documentação incompleta foram descartados e um total de 343, com idade média de 34,5 anos (variando de 20 a 70,1 anos), tratados por um período que variou de 0,6 a 5,2 anos (2 anos, em média), foram incluídos no estudo. As variáveis analisadas foram o tipo de má oclusão segundo Angle, a presença de hábitos, a história de traumatismos prévios, o tempo de uso de elásticos verticais, de elásticos de Classe II, do arco retangular, a osteotomia maxilar e o tratamento ortodôntico anterior. As radiografias periapicais foram analisadas quando projetadas com magnificação de 7 vezes. A diferença do comprimento radicular entre a radiografia final e a inicial foi determinada por um paquímetro, medindo da borda incisiva ao ápice. A forma da raiz foi ainda classificada em normal, achatada, pontiaguda, dilacerada, reabsorvida e em forma de garrafa. Nenhuma relação foi encontrada entre o tipo de má oclusão, o tempo de tratamento, o uso do arco retangular, a proximidade entre a raiz e o palato ou o tratamento com osteotomia da maxila e a reabsorção radicular. Verificaram que a quantidade de movimento radicular e a presença de raízes longas, estreitas e dilaceradas aumentam o risco de reabsorção. O uso de elásticos foi considerado um fator de risco apenas para os dentes que os 
suportam. Os autores ressaltaram que as variações individuais, nas respostas biológicas às forças e a predisposição genética podem ser fatores predisponentes mais importantes.

KJAER $^{68}$, ainda em 1995, visando encontrar um meio de diagnosticar a predisposição individual à reabsorção radicular apical, antes do tratamento ter sido iniciado, selecionou a documentação de 107 pacientes, os quais apresentavam mais de um terço de uma ou mais raízes reabsorvido durante o tratamento. O material selecionado, bastante heterogêneo, foi avaliado por 35 ortodontistas diferentes. Cento e cinco casos apresentavam radiografias panorâmicas e em muitos desses casos, além das panorâmicas, existiam intrabucais adicionais, porém, em dois casos existiam somente radiografias periapicais e interproximais. Os desvios morfológicos, como o padrão de reabsorção, a infra oclusão e a morfologia dentária foram registrados para a dentadura decídua. Na dentadura permanente, desvios como a morfologia da raiz e da coroa, agenesia e ectopia foram observados, assim como, foram registradas as invaginações e o taurodontismo. $\mathrm{O}$ autor encontrou reabsorção atípica (na dentadura decídua), em conexão com a erupção do dente permanente em 32 pacientes, reabsorção atípica externa na junção amelocementária em 5, infra oclusão em 14, invaginações em 45, coroas estreitas em 11 pacientes, encurtamento das raízes dos incisivos em 64, encurtamento das raízes dos pré -molares em 37, sendo que a raiz distal do primeiro molar inferior foi menor do que a mesial em 15 casos, encurtamento radicular generalizado na dentadura decídua em 7 pacientes, raízes estreitas e com forma de pipeta em 39, morfologias radiculares anormais em 22 pacientes, reabsorção dos dentes permanentes devido a um dente ectópico em 12 casos, taurodontismo em 34, agenesia em 22, ectopia em 41 casos, formação dentária tardia em 5 e alterações condilares em 8 pacientes. Analisando os achados, subjetivamente, o autor concluiu que há uma forte conecção entre as várias características dentárias morfológicas, como a 
invaginação, o comprimento radicular, a forma radicular, especialmente o taurodontismo, assim como entre as anomalias de dentição, como a ectopia e a agenesia e a tendência de reabsorção decorrente do tratamento. Sugeriu que há uma associação entre o padrão de reabsorção na dentadura decídua e a tendência à reabsorção na dentadura permanente. Recomendou que o clínico faça uma associação entre as alterações condilares, a mordida aberta anterior e as reabsorções radiculares decorrentes do tratamento ortodôntico. Reiterou, ainda, que as dentaduras com pronunciada reabsorção radicular decorrente do tratamento são as que apresentam desvio neuroectodérmico do desenvolvimento normal. A identificação desses desvios foi considerada uma importante parte no diagnóstico futuro da reabsorção, antes do planejamento ortodôntico, para reduzir a reabsorção radicular ortodonticamente induzida. Além disso, percebeu que o sexo feminino foi o mais afetado pela reabsorção.

No ano seguinte, BAUMRIND; KORN; BOYD ${ }^{19}$ determinaram a relação entre a magnitude e o deslocamento do incisivo central superior, durante o tratamento e a quantidade de reabsorção apical observada após a terapia com o aparelho fixo. Também examinaram a relação entre a reabsorção dos incisivos superiores e diversas outras variáveis relacionadas ao tratamento. Para tanto, analisaram as radiografias periapicais e cefalométricas laterais de 81 adultos, tratados por 3 diferentes especialistas. Os pacientes, para pertencerem à amostra, precisavam ter idade mínima de 20 anos ao início do tratamento, má oclusão de Classe I ou Classe II, tratados com a técnica do Arco de Canto e possuir sua documentação ortodôntica completa. Após analisarem as radiografias, os autores encontraram uma média de reabsorção de $1,36 \mathrm{~mm}$, bem como uma média de deslocamento do ápice de 0,83 $\mathrm{mm}$ no sentido horizontal e de $19 \mathrm{~mm}$ no sentido vertical. Verificaram uma média de $0,49 \mathrm{~mm}$ de reabsorção para cada milímetro de retração. Os autores concluíram que a intervenção ortodôntica está relacionada com a reabsorção radicular dos incisivos superiores, mesmo quando a posição destes 
é aparentemente a mesma nas radiografias pré e pós tratamento. A associação entre os movimentos de intrusão, extrusão e protrusão, a idade, o tipo de terapia realizada, com ou sem extrações, bem como a classificação da má oclusão, segundo Angle, e a quantidade de reabsorção não foi significante. O sexo masculino foi o mais afetado pela reabsorção do que o feminino. O aumento do tempo de tratamento foi positivamente associado ao aumento da reabsorção radicular, embora o fator mais significantemente associado à quantidade de reabsorção tenha sido o deslocamento apical do incisivo. Nenhuma combinação das variáveis testadas conseguiu explicar mais do que um terço da variabilidade individual total na tendência à reabsorção radicular. Para a identificação das associações que explicariam os dois terços adicionais da variação na resposta individual ao tratamento, seria preciso voltar a atenção para as medidas não avaliáveis nos cefalogramas laterais. Essas análises avaliariam medidas da condição pré tratamento, como o histórico médico, pessoal e familiar, doenças crônicas e agudas, desordens genéticas e metabólicas, traumatismos dentários e faciais anteriores ao tratamento, gravidade da má oclusão, caninos impactados ou posicionados ectopicamente e presença de mordida cruzada anterior. Além disso, essas análises iriam requerer uma avaliação das variações que ocorrem durante o tratamento, como a doença intercorrente, o traumatismo intercorrente e a mecânica do tratamento (incluindo o tempo, a duração e o nível de força dos fios retangulares, dos elásticos de Classe II, dos elásticos verticais, arcos utilitários, ancoragem extrabucal, torque e o método de retração).

TAITHONGCHAI; SOOKKORN; KILLIANY ${ }^{130}$, no mesmo ano, visando determinar a relação entre as medidas da face e dentoalveolares, antes do tratamento e a quantidade de encurtamento radicular pós tratamento, examinaram as radiografias periapicais e cefalométricas laterais de 400 pacientes tratados na clínica da faculdade, por diferentes técnicas. Duzentos e trinta e cinco pacientes foram tratados com a técnica do Arco de Canto, 72, 
com a técnica de Tweed (Arco de Canto), 58, com Begg e 35, com a técnica do Arco Reto. Os dentes analisados apresentavam todas as raízes formadas antes do tratamento, sem história de traumatismo prévio, sem restaurações ou endodontia. O tratamento foi realizado em uma única fase e os pacientes apresentavam documentação ortodôntica completa. Foi encontrada reabsorção média de 2,04 $\mathrm{mm}$, porém apenas $2 \%$ dos pacientes apresentaram perda radicular de mais de $5 \mathrm{~mm}$. Das variáveis analisadas, somente a idade e o tempo de tratamento demonstraram relação significante com a reabsorção radicular. Não conseguiram comprovar uma relação entre as medidas dentoalveolares e as da face e a quantidade de encurtamento, então afirmaram que enquanto essa relação não for encontrada, ou seja, enquanto não se puder prever a quantidade de reabsorção, todos os pacientes devem ser alertados para a possibilidade de encurtamento radicular com o tratamento. Os autores ressaltaram que radiografias periódicas devem ser realizadas e quando a reabsorção for diagnosticada, o tratamento deve cessar ou o plano de tratamento deve ser reavaliado.

ALEXANDER $^{2}$, em 1996, avaliou as diferenças na extensão da reabsorção radicular entre a mecânica do arco contínuo e do arco segmentado. Para tal, utilizou 64 pacientes, com idade variando entre 11 anos e 2 meses e 14 anos, que apresentavam má oclusão de Classe I, com apinhamento anterior, os quais necessitavam de extração dos 4 primeiros pré molares. Apresentavam, ainda, relação das bases apicais, ângulo do plano mandibular e altura facial normais e nenhum deles possuía história anterior de traumatismo nos dentes anteriores. Os pacientes foram divididos em 2 grupos: do grupo 1 faziam parte 28 pacientes tratados com a mecânica do arco contínuo e do grupo 2, aqueles tratados com retração dos caninos com um arco seccionado de TMA. Todos os pacientes foram tratados com o aparelho pré programado de Roth, com ranhura 0,018 polegada nos incisivos e 0,022 polegada nos demais dentes. Somente os caninos foram retraídos 
completamente e os demais anteriores foram retraídos posteriormente com molas Sentalloy de 300 gramas de força. O tempo de tratamento total variou de 22 a 27 meses para ambos os grupos. A reabsorção radicular foi analisada em radiografias panorâmicas e oclusais, obtidas pelo mesmo operador, imediatamente após a remoção do aparelho. Os incisivos foram analisados e classificados por escores, variando de $\mathrm{O}$ a 3 . As radiografias cefalométricas laterais foram utilizadas para determinar a quantidade e a direção do movimento dos incisivos. Os autores encontraram uma quantidade alta de reabsorção para as duas técnicas utilizadas. Os dentes mais reabsorvidos foram os incisivos superiores, principalmente os laterais. As alterações lineares e angulares dos incisivos não apresentaram diferenças estatisticamente significantes. Também não foi encontrada diferença estatisticamente significante na quantidade de reabsorção nas duas técnicas utilizadas, indicando que esse efeito indesejável do tratamento pode estar relacionado com uma variação individual.

HARRIS; KINERET; TOLLEY54, em 1997, analisaram a influência dos fatores genéticos na quantidade de reabsorção encontrada após o tratamento ortodôntico, por meio de radiografias panorâmicas e cefalométricas laterais, pré e pós tratamento, de 103 pares de irmãos, todos tratados com a mesma técnica e pelo mesmo ortodontista. As seguintes raízes foram medidas: as dos incisivos centrais superiores e inferiores e a raiz mesial e distal dos primeiros molares inferiores. Foram realizadas, ainda, correlações entre a quantidade de reabsorção encontrada e o sexo, a idade do paciente e a gravidade da má oclusão. Verificaram quantidades estatisticamente significantes de reabsorção nas raízes analisadas, sendo que a perda radicular média foi de 1,5 mm para os incisivos inferiores e de 2,3 $\mathrm{mm}$ para os incisivos superiores. Não houve dimorfismo sexual e a estimativa da hereditariedade foi significantemente alta (70\%) para reabsorção em 3 das raízes examinadas. Não foi encontrada relação entre a quantidade de reabsorção e a classificação 
da má oclusão, segundo Angle. Algumas pessoas parecem ser mais resistentes à reabsorção, enquanto outras são mais suscetíveis, levando a crer que, clinicamente, os irmãos experimentam níveis similares de reabsorção, decorrentes do tratamento ortodôntico. Considerando que a natureza da má oclusão, o plano de tratamento, o tipo de aparelho utilizado e o profissional que o instalou foram constantes, as diferenças na quantidade de reabsorção encontradas podem ter sido determinadas pelo genótipo. Os inúmeros trabalhos apresentados a respeito dos diversos fatores que podem levar à reabsorção radicular apical e a constante busca dos ortodontistas por uma técnica que minimize esse efeito deletério, induziram esta pesquisa, na qual comparar se á a quantidade de reabsorção apical, decorrente do tratamento ortodôntico, na técnica do Arco de Canto Simplificada, na técnica do Arco Reto e na Terapia Bioeficiente. 


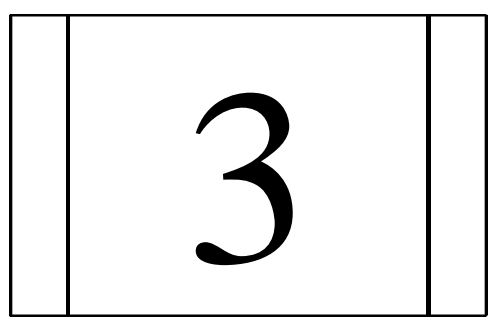

PROPOSICÃO 


\section{PROPOSIÇÃO}

Este trabalho foi realizado com os seguintes

objetivos:

1. Comparar as técnicas do Arco de Canto Simplificada, do Arco Reto e a Terapia Bioeficiente:

- Quanto ao grau de reabsorção radicular apical decorrente do tratamento ortodôntico;

- Quanto ao tempo necessário para o tratamento;

2. Avaliar a freqüência e a intensidade da reabsorção radicular apical decorrente do tratamento ortodôntico;

3. Avaliar a prevalência de reabsorção nos incisivos. 


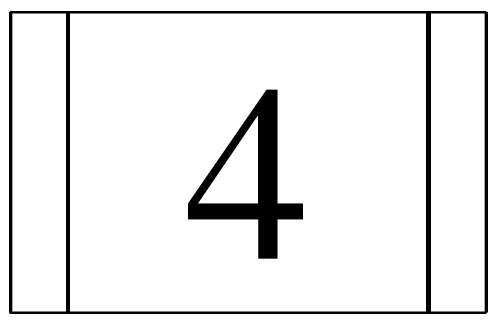

MATERIAL E MÉTODOS 


\section{MATERIAL E MÉTODOS}

\subsection{MATERIAL}

$\mathbf{P}_{\text {ara avaliar a reabsorção radicular decorrente do tratamento }}$ ortodôntico em pacientes tratados com a técnica do Arco de Canto Simplificada, do Arco Reto e com a Terapia Bioeficiente, foi compulsada a documentação clínica de 90 pacientes, com idade entre 10 anos e 1 mês e 26 anos e 10 meses, sem distinção de raça ou sexo e independentemente do tipo de má oclusão apresentada. Os grupos 1 e 2 foram formados por 30 pacientes cada, tratados com a técnica do Arco de Canto Simplificada e do Arco Reto, respectivamente, nas Clínicas dos cursos de Pós -Graduação e de Especialização em Ortodontia, da Faculdade de Odontologia de Bauru, da Universidade de São Paulo (FOB/USP). Trinta pacientes foram tratados pela Terapia Bioeficiente, 19, nas Clínicas do curso de Pós-Graduação e Especialização em Ortodontia da FOB e os 11 restantes, em uma clínica particular, formando o grupo 3.

A técnica do Arco de Canto Simplificada (Figura 4.1), empregada no grupo 1, caracteriza -se, basicamente, pela utilização de bráquetes convencionais", com ranhura 0,022 x 0,028 polegada e pela utilização de arco extrabucal (AEB), placa lábioativa (PLA) e, ainda, elásticos de Classe III, quando necessário, como ancoragem. Neste grupo, 11 pacientes eram do sexo feminino e 19 do sexo masculino, com idade média de 13,92 anos, ao início do tratamento. Onze casos foram tratados com 4 extrações, 3 com extração de 3 dentes, um com extração de apenas 2 dentes e 15 sem extrações.

*Morelli, Sorocaba. 
A técnica do Arco Reto (Figura 4.2), utilizada no grupo 2, apresenta como principal diferença da acima citada o fato dos bráquetes serem pré ajustados. Os bráquetes utilizados foram da prescrição Roth*, com ranhura 0,022 x 0,028 polegada. Neste grupo, 15 pacientes eram do sexo feminino e 15 do sexo masculino, com idade média de 14,18 anos, ao início do tratamento. Treze casos foram tratados com 4 extrações, 5 com 2 extrações e 12 sem extrações.

A Terapia Bioeficiente (Figura 4.3), empregada no grupo 3, caracteriza se pela utilização de bráquetes triangulares, com ranhura 0,022 x 0,028 polegada, associados a fios superelásticos Bioforce Ionguard**. Neste grupo, 14 pacientes eram do sexo feminino e 16 do sexo masculino, com idade média de 14,29 anos, ao início do tratamento. Quinze casos foram tratados com 4 extrações, 6 com 2 extrações, um com apenas 1 extração e 8 sem extrações.

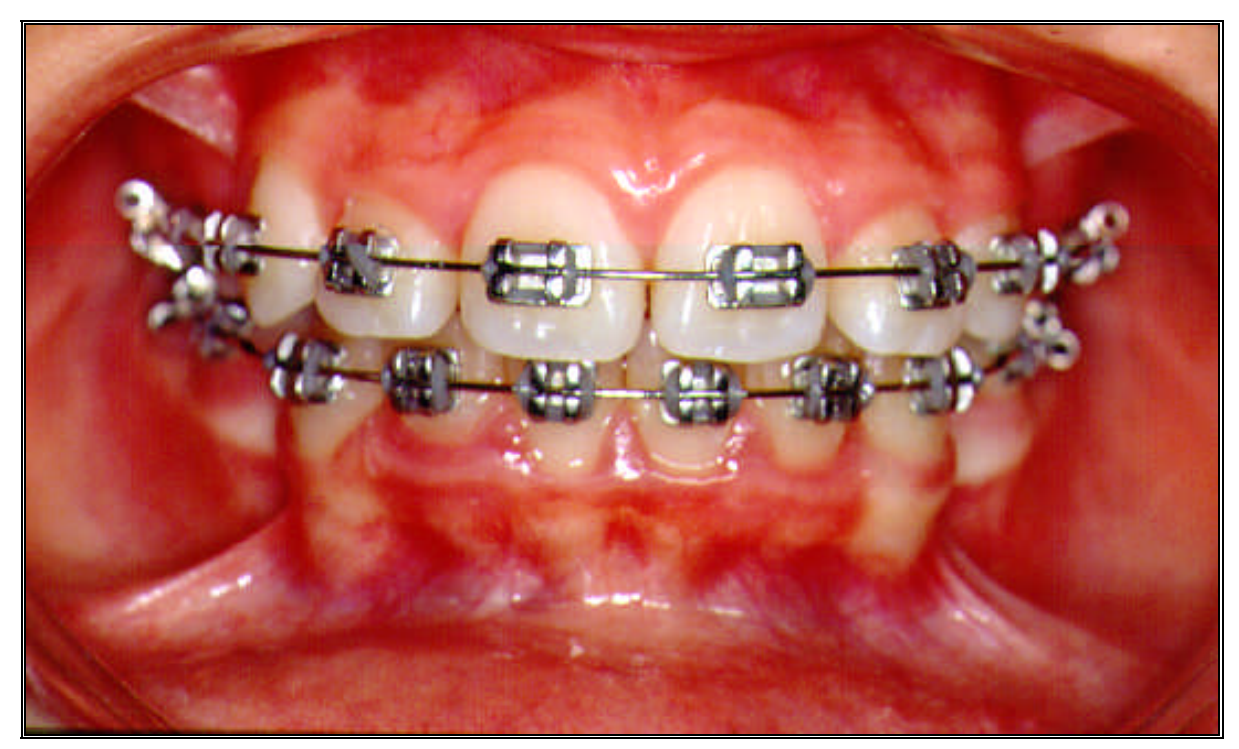

FIGURA 4.1 Técnica do Arco de Canto Simplificada

" Lancer Orthodontics Inc., Califórnia.

${ }^{* *}$ GAC International Inc., NY. 


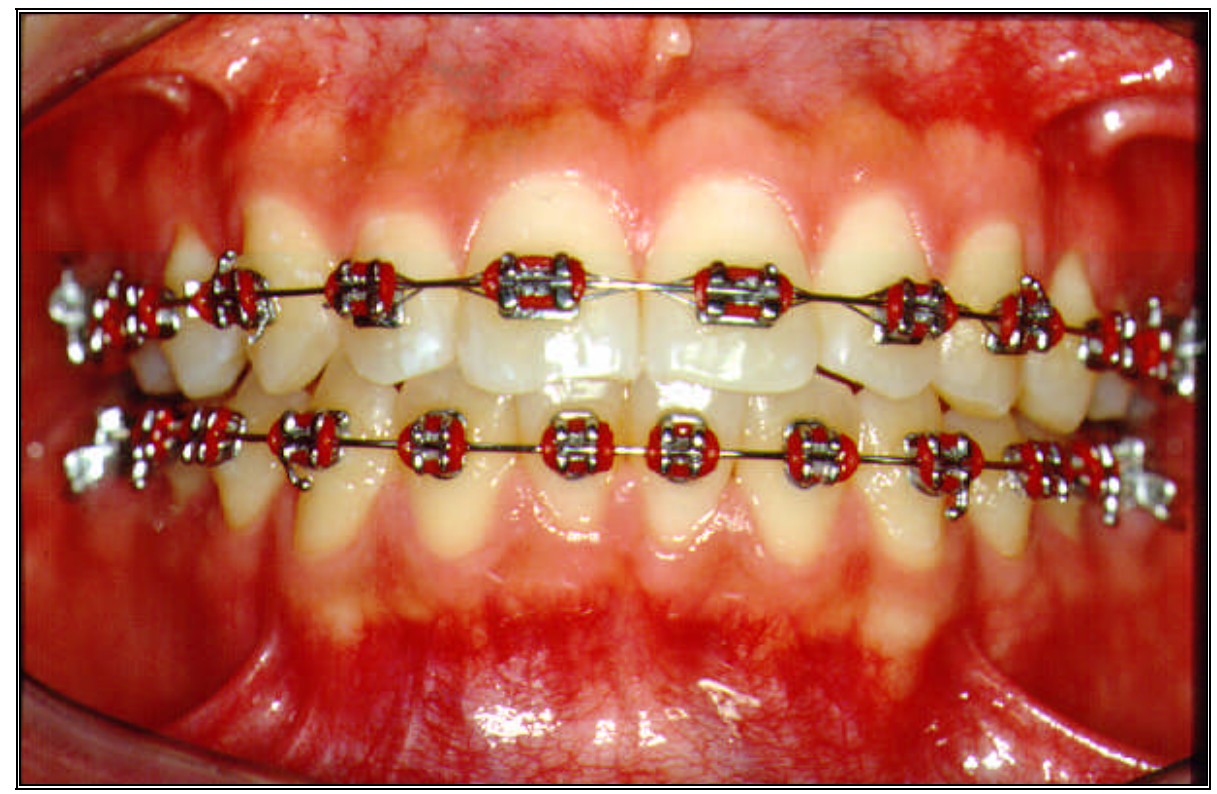

FIGURA $4.2 \sim$ Técnica do Arco Reto

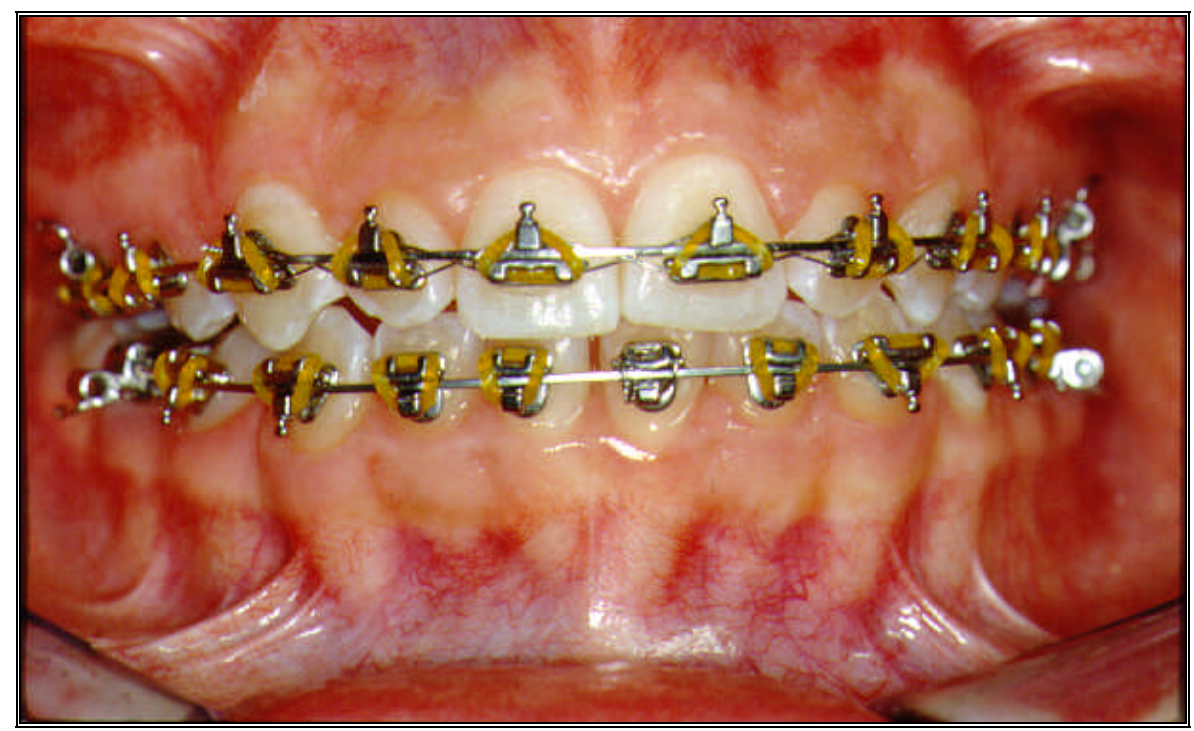

FIGURA $4.3 \sim$ Terapia Bioeficiente 
As médias de idade e número de extrações para cada grupo estudado encontram $\sim$ se na Tabela 4.1.

TABELA 4.1 Média de idade e número de extrações para os 3 grupos estudados

\begin{tabular}{cccc}
\hline \hline & GRUPO 1 & GRUPO 2 & GRUPO 3 \\
\hline \hline IDADE (MESES) & $\begin{array}{c}167,13 \\
(D . P .=40,25)\end{array}$ & $\begin{array}{c}170,26 \\
(\text { D.P. }=35,93)\end{array}$ & $\begin{array}{c}171,5 \\
(\text { D.P. }=41,73)\end{array}$ \\
\hline \multirow{2}{*}{ N $^{\circ}$ DE EXTRAÇÕES } & 1,79 & 2,06 & 2,43 \\
& (D.P. $=1,93)$ & (D.P. $=1,85)$ & (D.P.=1,73) \\
\hline
\end{tabular}

Para a seleção da amostra, os pacientes cujos dentes apresentavam reabsorção radicular apical ou tratamento endodôntico, diagnosticados nas radiografias pré tratamento, foram excluídos, assim como os pacientes cuja documentação ortodôntica inicial apresentava se incompleta. Também foram eliminadas as radiografias que evidenciavam distorções ou falta de nitidez.

Para a quantificação da reabsorção, foram examinadas apenas as radiografias periapicais pós tratamento dos incisivos superiores e inferiores. Setecentos e doze dentes foram analisados. Optou se por trabalhar somente com os incisivos, por serem os dentes sujeitos à maior movimentação durante o tratamento, principalmente nos casos com extrações e porque a grande maioria dos autores concorda que são esses os dentes reabsorvidos com maior freqüência e intensidade durante $o$ tratamento ortodôntico ${ }^{1,2,15,35,38,52,55,65,67,92,101}$.

A documentação ortodôntica dos pacientes foi utilizada para 
determinar o sexo, a idade do paciente ao início do tratamento, o tipo de tratamento ao qual o paciente foi submetido (com ou sem extrações), a técnica utilizada e a duração do mesmo. O tratamento foi considerado iniciado quando o primeiro fio foi instalado e finalizado quando o aparelho fixo foi removido.

\subsection{MÉTODOS}

\subsubsection{Radiografias}

As radiografias periapicais pós tratamento dos pacientes tratados nas Clínicas de Pós Graduação e Especialização da FOB foram obtidas por um único operador, com um aparelho de raios X DABI 70 Spectro $1070 \mathrm{X}$, regulado para $70 \mathrm{KV}$ e 10 $\mathrm{mA}$, com a técnica do paralelismo (cone longo), indicada na pesquisa de sutis alterações nas estruturas periapicais ou periodontais, ou quando há necessidade de se conhecer o tamanho real das estruturas dentárias,3,447,74. Os filmes utilizados foram da marca Kodak "Ecta Speed" EP 21 e os ângulos, determinados pelo uso de um posicionador intra oral XCP * $\mathrm{O}$ tempo de exposição foi de 1 segundo. As radiografias dos pacientes tratados na clínica particular foram realizadas por dois operadores distintos, com o mesmo tipo de posicionador descrito acima, em um aparelho Yoshida X 70 F, regulado para $70 \mathrm{KV}$ e $15 \mathrm{~mA}$, também pela técnica do paralelismo. Os filmes foram os da marca Kodak DF 58, expostos por 0,9 segundos.

Todas as radiografias, em ambos os casos, foram processadas automaticamente ${ }^{* *}$.

\footnotetext{
* Rinn Dentisply.

** Processadora automática Peri pro II.
} 
A possível falta de padronização entre as radiografias dos pacientes da FOB e dos pacientes da clínica particular, tomadas por diferentes operadores, não trouxe dificuldades, já que a reabsorção foi quantificada pelo método de escores, descrito a seguir.

Para a quantificação da reabsorção radicular apical, a exemplo de outros pesquisadores, utilizou se o método proposto por LEVANDER; MALMGREEN ${ }^{76}$, classificando a reabsorção em 5 graus (Figura 4.4):

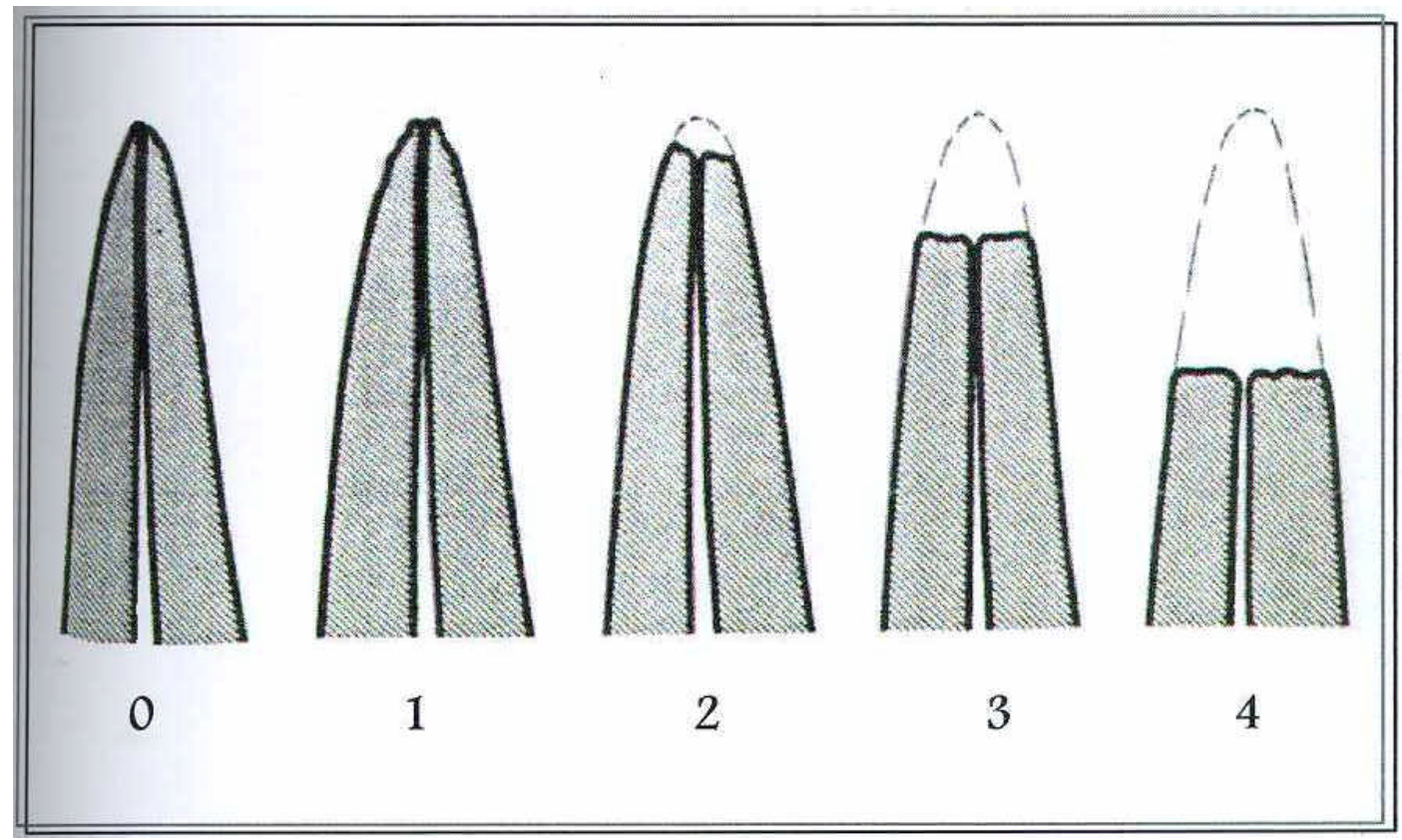

FIGURA 4.4 Classificação dos graus de reabsorção segundo LEVANDER; MALMGREN ${ }^{76}$ 
- grau O - Ausência de reabsorção radicular (Figura 4.5);

- grau 1 Reabsorção leve, observando se apenas contorno irregular, com a raiz apresentando o seu comprimento normal (Figura 4.6);

- grau 2 Reabsorção moderada, com pequena perda radicular e o ápice exibindo um contorno quase retilíneo (Figura 4.7);

- grau 3 Reabsorção acentuada, com grande perda radicular, atingindo quase 1/3 do seu comprimento (Figura 4.8);

- grau 4 Reabsorção extrema, com perda de mais de 1/3 do comprimento radicular (Figura 4.9).

A análise radiográfica foi realizada em uma sala escurecida, na qual a única fonte de luz provinha do negatoscópio. As radiografias foram colocadas em cartões, dispostas sobre o negatoscópio e cobertas com um anteparo de cartolina preta, com uma abertura central do tamanho de uma película radiográfica. Deste modo, podiam ser visualizadas uma de cada vez, sem influência de luz externa. A análise foi realizada com auxílio de uma lupa, com magnificação de 2 vezes, por dois examinadores, ambos alunos do curso de Pós Graduação em Ortodontia da FOB. A classificação dos graus de reabsorção de cada dente foi anotada individualmente na ficha de cada paciente (Figura 4.10). O examinador A, ao classificar a reabsorção, não conhecia os resultados do examinador B, e vice versa (estudo cego).

Posteriormente, outras informações foram acrescentadas às fichas, como a idade do paciente, a duração do tratamento, a técnica utilizada, o sexo e, ainda, se o paciente foi tratado com ou sem extrações. 


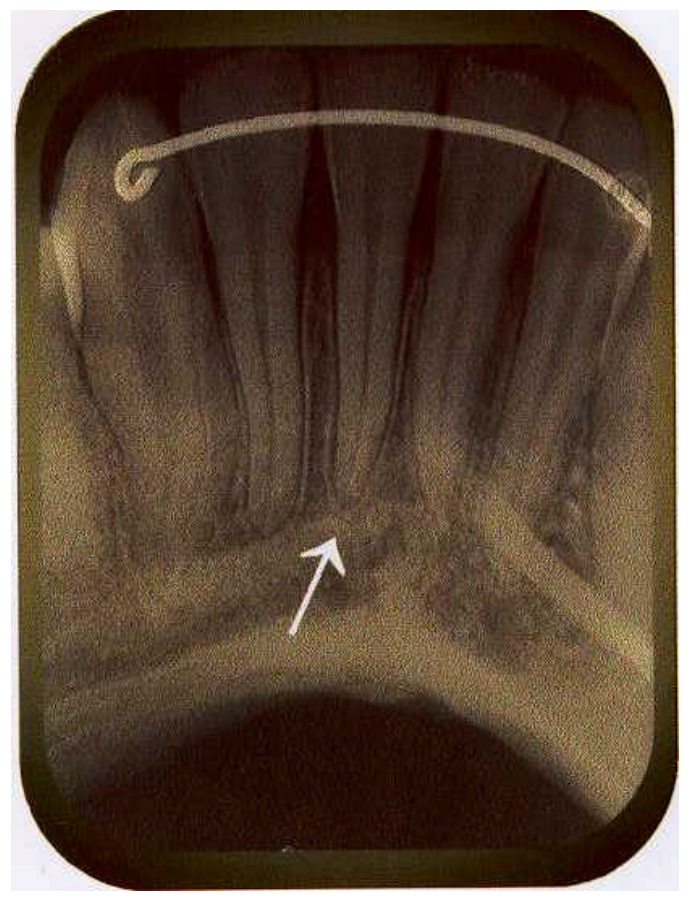

FIGURA 4.5 Radiografia periapical de incisivo com grau O de reabsorção

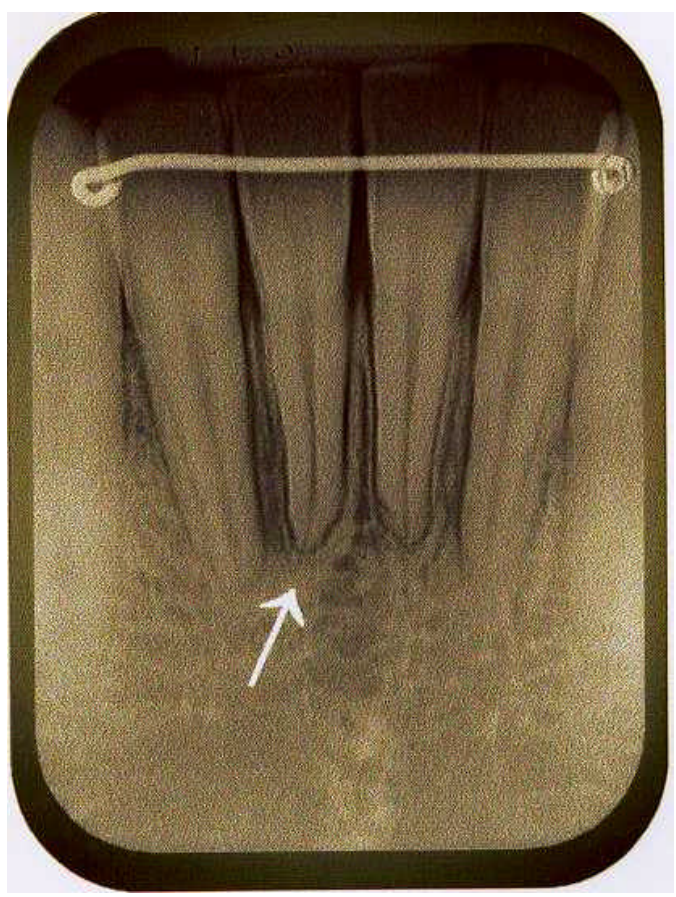

FIGURA 4.6 Radiografia periapical de incisivo com grau 1 de reabsorção 


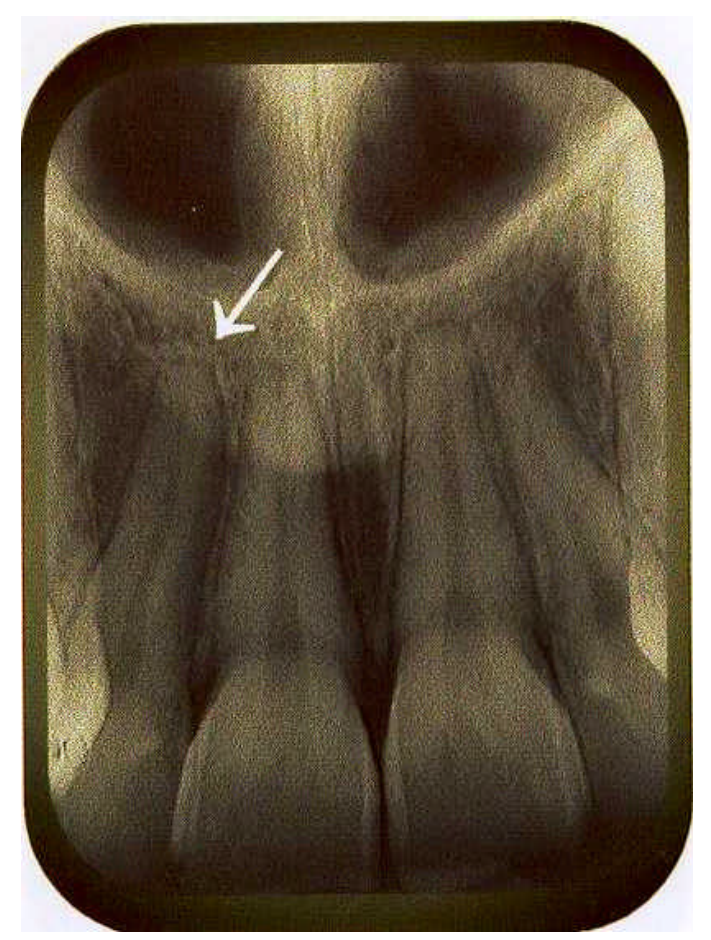

FIGURA 4.7 Radiografia periapical de incisivo com grau 2 de reabsorção

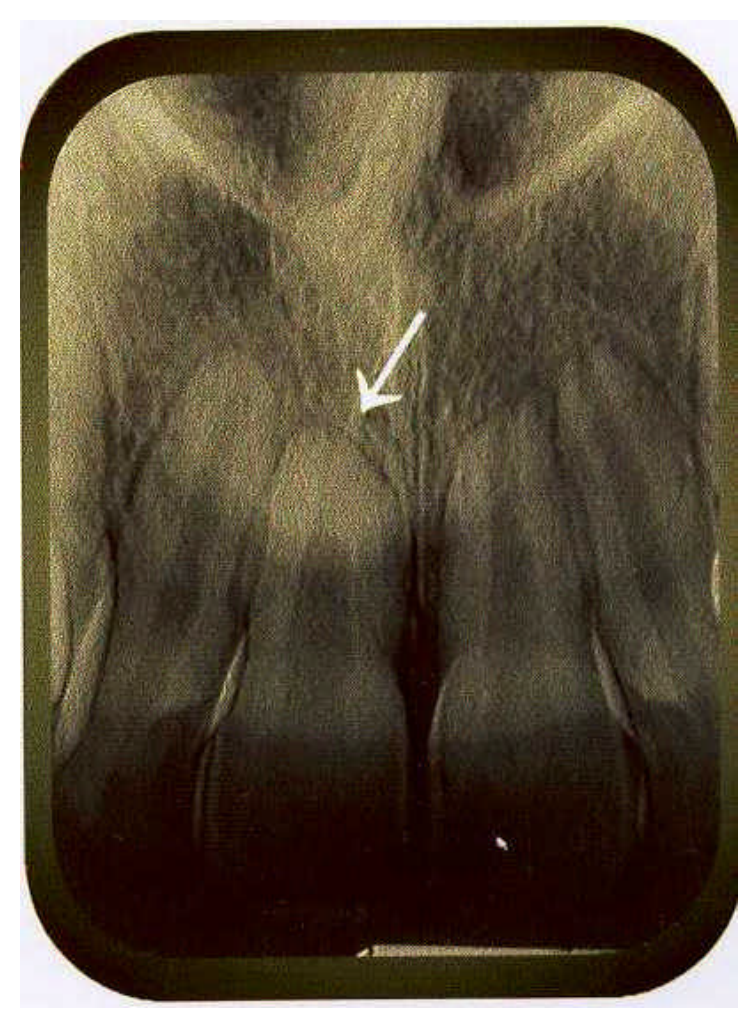

FIGURA 4.8 Radiografia periapical de incisivo com grau 3 de reabsorção 


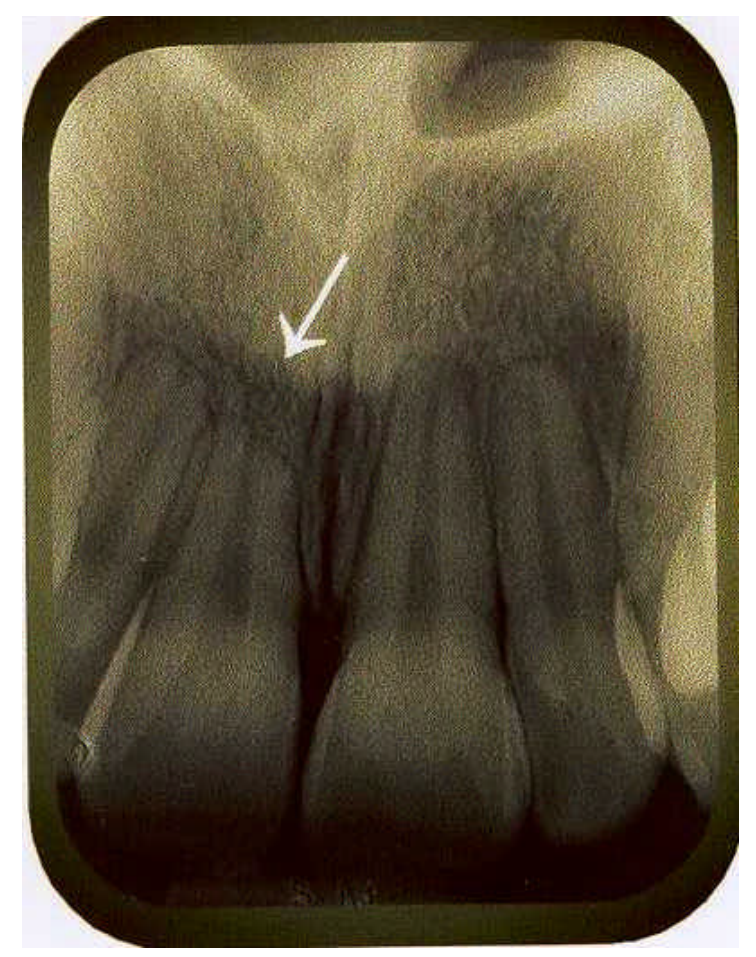

FIGURA 4.9 Radiografia periapical de incisivo com grau 4 de reabsorção 


\section{UNIVERSIDADE DE SÃO PAULO \\ FACULDADE DE ODONTOLOGIA DE BAURU \\ DISCIPLINA DE ORTODONTIA}

NOME:

N. ${ }^{\circ}$

SEXO:

IDADE:

TÉCNICA:

EXTRAÇÕES:

\section{EXAMINADOR:}

\section{PERIAPICAIS}

INCISIVOS SUPERIORES

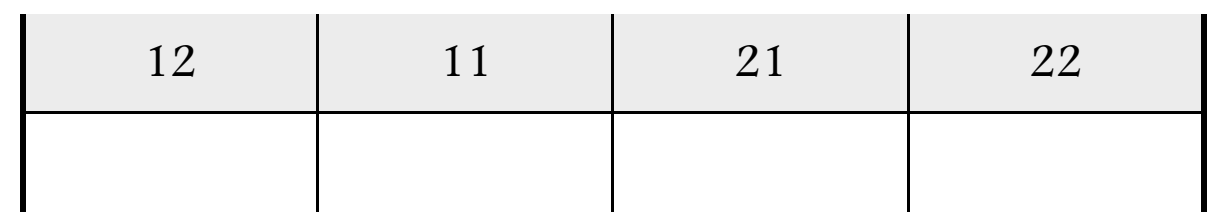

INCISIVOS INFERIORES

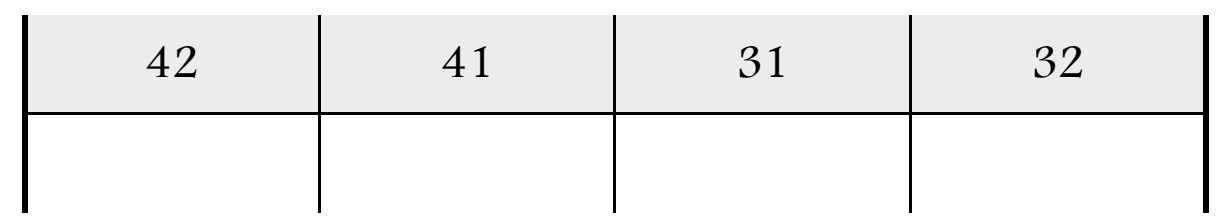

FIGURA 4.10 Ficha utilizada para anotação dos graus de reabsorção 


\subsubsection{Erro do método}

\subsubsection{Erro intra examinador}

Trinta casos foram aleatoriamente selecionados (dez de cada grupo) e medidos novamente pelo mesmo examinador (examinador A). As medidas repetidas foram testadas pelo coeficiente de concordância de Kendall ${ }^{37}$. O coeficiente de concordância de Kendall ${ }^{37}$ demonstrou um excelente nível de calibração intra examinador (Tabela 4.2).

TABELA 4.2 Erro intra examinador

\begin{tabular}{ccc}
\hline \hline GRUPOS & VALOR COEFICIENTE & $p$ \\
\hline \hline 1 & 0,934 & $<0,0001$ \\
\hline 2 & 0,828 & $<0,0001$ \\
\hline 3 & 0,958 & $<0,0001$ \\
\hline GERAL & 0,912 & $<0,0001$ \\
\hline
\end{tabular}

\subsubsection{Erro interexaminadores}

Todas as 180 radiografias foram analisadas por dois examinadores e a calibração entre os examinadores A e B foi testada pelo coeficiente de concordância de Kendall ${ }^{37}$. Os resultados foram semelhantes aos da calibração intra examinador, apontando para um alto nível de concordância, estatisticamente significante, conforme os dados apresentados na Tabela 4.3. Por esse motivo, na análise estatística, as medidas do examinador B não precisaram ser utilizadas, ou seja, estas serviram apenas de referência para a precisão das medidas realizadas pelo examinador A. 
TABELA 4.3 Erro interexaminadores

\begin{tabular}{ccc}
\hline \hline GRUPO & VALOR COEFICIENTE & $p$ \\
\hline \hline 1 & 0,846 & $<0,0001$ \\
\hline 2 & 0,909 & $<0,0001$ \\
\hline 3 & 0,898 & $<0,0001$ \\
\hline
\end{tabular}

\subsection{ANÁLISE ESTATÍSTICA}

\subsubsection{Comparações entre os grupos}

- Quantidade de reabsorção

$\mathrm{Na}$ análise das radiografias periapicais, a quantidade de reabsorção, nas três técnicas ortodônticas utilizadas, foi comparada por meio do teste não paramétrico de Kruskal Wallis ${ }^{37}$. Como alguns pacientes do grupo 3 foram tratados em uma clínica particular, para analisar o quanto isto influenciou nos resultados, optou se por verificar se existiu diferença na quantidade de reabsorção encontrada dentro do grupo 3, entre os pacientes tratados na clínica de Especialização e Pós Graduação da FOB e na clínica particular. Para tal, utilizou $\sim$ se o teste de Mann $\sim$ Whitney ${ }^{37}$.

- Tempo de tratamento

O tempo de tratamento, nos 3 grupos, foi comparado pela análise de variância (Teste F). A equivalência entre os tempos médios de tratamento foi determinada pelo teste de Scheffé.

- Avaliação complementar

Diante da dificuldade de padronização da amostra em relação ao tipo de má oclusão dos pacientes, ao início do tratamento, optou se por comparar a quantidade de extrações realizadas, em média, em cada grupo, para evitar que esse fator confundisse a interpretação dos resultados obtidos. A quantidade de extrações realizadas em cada grupo foi comparada pela análise de variância (Teste F). 


\subsubsection{Quantidade de reabsorção radicular decorrente do tratamento ortodôntico}

Para avaliar a quantidade de reabsorção radicular decorrente do tratamento ortodôntico, calculou se a porcentagem de reabsorção encontrada na amostra como um todo.

\subsubsection{Prevalência de reabsorção nos incisivos}

A prevalência de reabsorção em cada incisivo, foi determinada pelo teste de Kruskal Wallis ${ }^{37}$. 


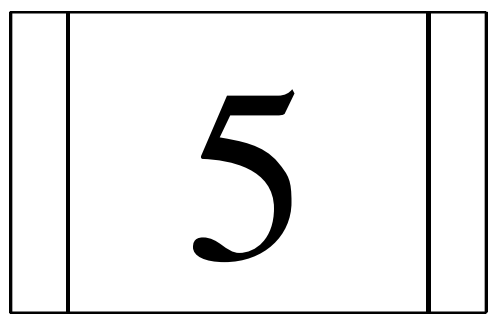

RESULTADOS 


\section{RESULTADOS}

\subsection{COMPARAÇÕES ENTRE OS GRUPOS}

- Quantidade de reabsorção

Após a análise apurada das radiografias e a posterior classificação dos graus de reabsorção radicular apical, os dados foram tabulados e submetidos à avaliação estatística, fornecendo os resultados descritos a seguir.

No grupo 1, formado por pacientes tratados com a técnica do Arco de Canto Simplificada, 239 dentes foram analisados, dos quais apenas 2 não apresentaram reabsorção radicular visível radiograficamente, 86 mostraram reabsorção leve, 145 , reabsorção moderada, 4, reabsorção acentuada e somente 2 dentes apresentaram reabsorção extrema (Tabela 5.1/Figura 5.1).

No grupo 2, formado por pacientes tratados com a técnica do Arco Reto, 239 dentes foram examinados, dos quais nenhum foi classificado com grau 0, 86 apresentaram reabsorção leve, 150 apresentaram reabsorção moderada, 2, reabsorção acentuada e somente um apresentou reabsorção extrema (Tabela 5.1/Figura 5.1).

No grupo 3, formado por pacientes tratados com a Terapia Bioeficiente, 234 dentes foram examinados, dos quais 14 não apresentaram reabsorção radicular detectável radiograficamente, 131 apresentaram reabsorção leve, 85, reabsorção moderada, 4 reabsorção acentuada e nenhum dente mostrou reabsorção extrema (Tabela 5.1/Figura 5.1). 
TABELA 5.1 Escores obtidos nos grupos 1, 2 e $3 \quad(n=712)$

\begin{tabular}{|c|c|c|c|c|c|c|c|c|c|c|}
\hline \multirow{3}{*}{ GRUPOS } & \multicolumn{10}{|c|}{ ESCORES } \\
\hline & \multicolumn{2}{|c|}{0} & \multicolumn{2}{|c|}{1} & \multicolumn{2}{|c|}{2} & \multicolumn{2}{|c|}{3} & \multicolumn{2}{|c|}{4} \\
\hline & $n$ & $\%$ & $\mathbf{N}$ & $\%$ & $\mathrm{n}$ & $\%$ & $n$ & $\%$ & $n$ & $\%$ \\
\hline 1 & 2 & 0,84 & 86 & 35,98 & 145 & 60,66 & 4 & 1,67 & 2 & 0,84 \\
\hline 2 & 0 & 0 & 86 & 35,98 & 150 & 62,76 & 2 & 0,84 & 1 & 0,42 \\
\hline 3 & 14 & 5,98 & 131 & 55,98 & 85 & 36,32 & 4 & 1,71 & 0 & 0 \\
\hline
\end{tabular}

$\mathrm{n}=$ número de dentes

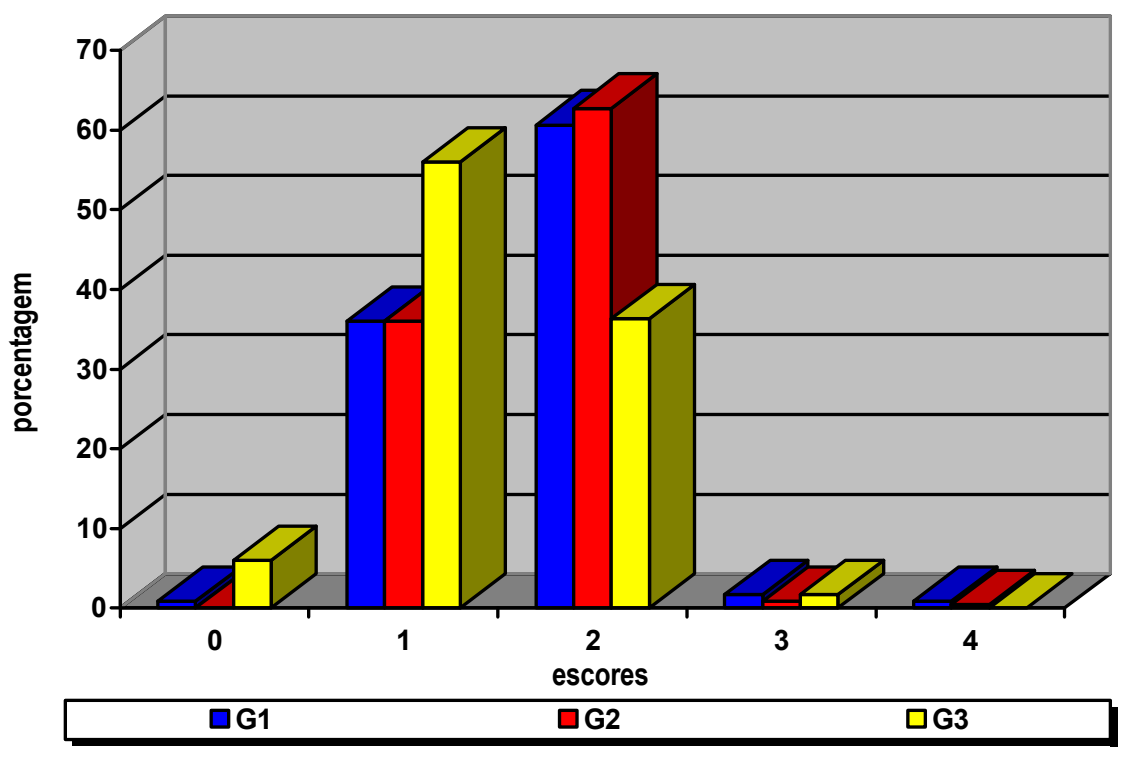

FIGURA 5.1 Porcentagem de dentes classificados com os escores 0, 1, 2, 3 e 4, nos 3 grupos estudados $(n=712)$ 
Comparando os graus de reabsorção radicular encontrados nos 3 grupos, verificou $\sim$ se que o grupo 3 apresentou menos reabsorção, em média, que os grupos 1 e 2 e que estes foram equivalentes entre si (Tabela 5.2/Figura 5.2).

TABELA 5.2 Comparação da quantidade de reabsorção nas 3 técnicas utilizadas (teste de Kruskal -Wallis)

$\mathrm{T}=45,25(\mathrm{p}<0,0001)$

\begin{tabular}{cr|r}
\hline \hline GRUPOS & POSTO MÉDIO $(p<0,01)$ \\
\hline \hline 1 & 156,5 & \\
\hline 2 & 156,0 & \\
\hline 3 & 79,5 & \\
\hline
\end{tabular}

estatisticamente equivalentes

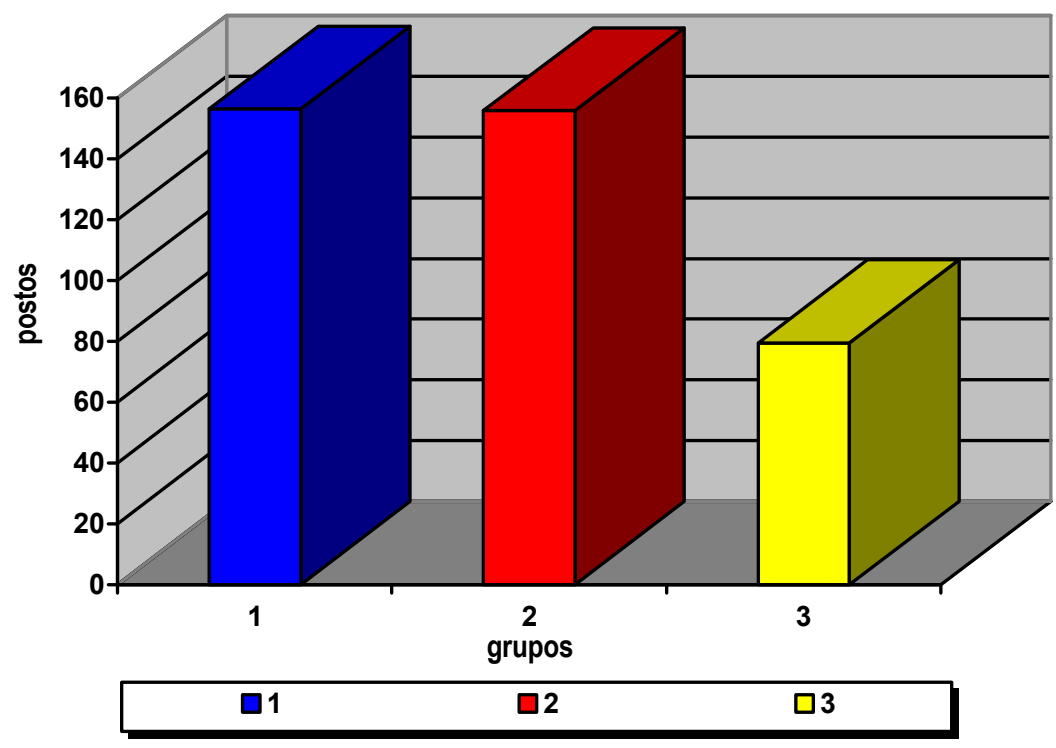

FIGURA 5.2 Comparação da quantidade de reabsorção encontrada individualmente, nos 3 grupos estudados 
Comparando os grupos separadamente, verificou $\sim$ se que não existiu diferença estatisticamente significante entre a quantidade de reabsorção encontrada entre os grupos 1 e 2. Por outro lado, comparando o grupo 3 com os demais, percebeu se, novamente, que este apresentou menos reabsorção (Tabela 5.3).

TABELA 5.3 Comparações individuais entre os grupos 1 e 2, 1 e 3 e 2 e 3 (teste de Kruskal Wallis )

\begin{tabular}{cccc}
\hline \hline COMPARAÇÕES INDIVIDUAIS & VALOR CRÍTICO & DIFERENÇAS & $\mathrm{p}$ \\
\hline \hline G1 X G2 & 10,96 & 4,603 & $\mathrm{~ns}$ \\
\hline G1 X G3 & 10,96 & 93,14 & $<0,01$ \\
\hline G2 X G3 & 10,96 & 97,74 & $<0,01$ \\
\hline
\end{tabular}

Após os resultados das comparações individuais, em função da grande diferença encontrada entre o grupo 3 e os demais, optou se por analisar, separadamente e descritivamente, os graus de reabsorção encontrados nos dentes superiores e inferiores, com o objetivo de visualizar em qual arco essa diferença foi maior (Tabela 5.4/Figura 5.3 e Tabela 5.5/Figura 5.4). 
TABELA 5.4 Escores encontrados nos dentes superiores, nos 3 grupos estudados (n=355)

\begin{tabular}{|c|c|c|c|c|c|c|c|c|c|c|}
\hline \multirow{3}{*}{ GRUPOS } & \multicolumn{10}{|c|}{ ESCORES } \\
\hline & \multicolumn{2}{|c|}{0} & \multicolumn{2}{|c|}{1} & \multicolumn{2}{|c|}{2} & \multicolumn{2}{|c|}{3} & \multicolumn{2}{|c|}{4} \\
\hline & $\mathrm{n}$ & $\%$ & $\mathrm{n}$ & $\%$ & $\mathrm{n}$ & $\%$ & $\mathrm{n}$ & $\%$ & $\mathrm{n}$ & $\%$ \\
\hline 1 & 0 & 0 & 40 & 33,61 & 73 & 61,34 & 4 & 3,36 & 2 & 1,68 \\
\hline 2 & 0 & 0 & 36 & 30 & 81 & 67,5 & 2 & 1,67 & 1 & 0,83 \\
\hline 3 & 2 & 1,72 & 46 & 39,66 & 64 & 55,17 & 4 & 3,45 & 0 & 0 \\
\hline
\end{tabular}

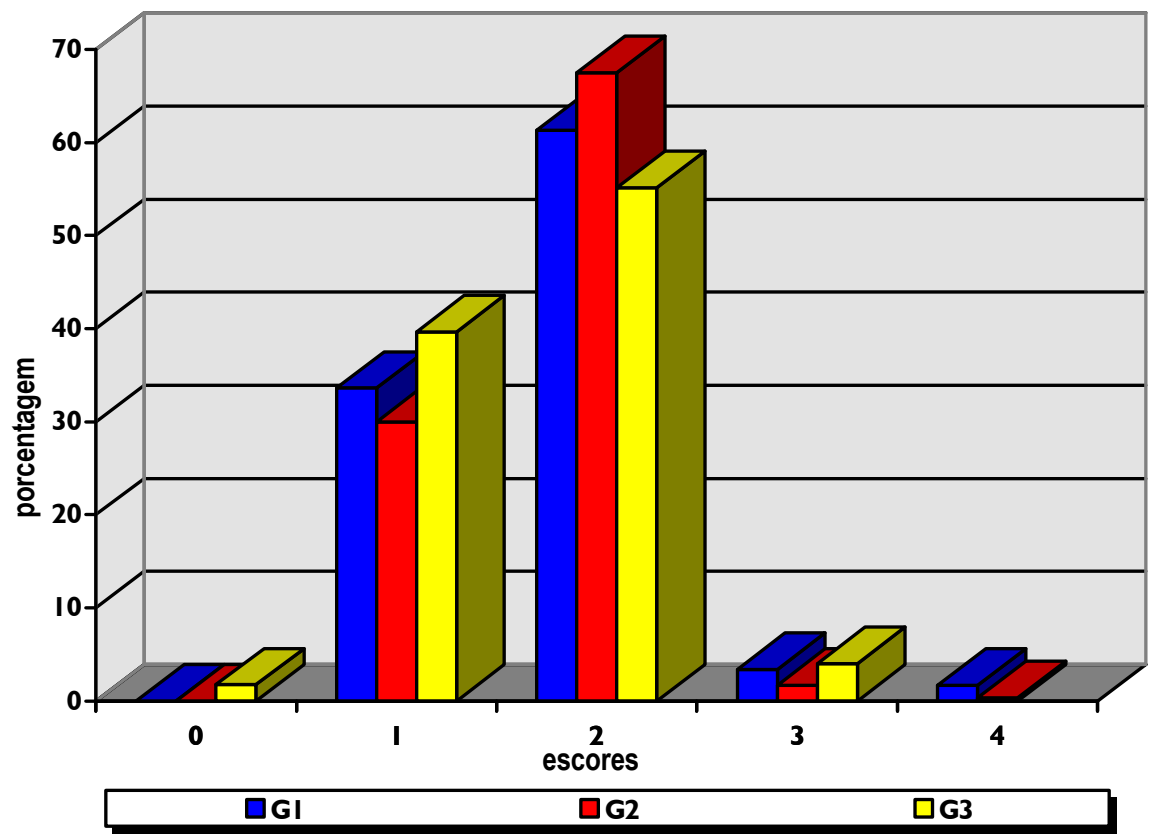

FIGURA 5.3 Comparação da quantidade de reabsorção encontrada nos dentes superiores, nos 3 grupos estudados $(n=355)$ 
TABELA 5.5 Escores encontrados nos dentes inferiores, nos 3 grupos estudados (n=357)

\begin{tabular}{|c|c|c|c|c|c|c|c|c|c|c|}
\hline \multirow{3}{*}{ GRUPOS } & \multicolumn{10}{|c|}{ ESCORES } \\
\hline & \multicolumn{2}{|c|}{0} & \multicolumn{2}{|c|}{1} & \multicolumn{2}{|c|}{2} & \multicolumn{2}{|c|}{3} & \multicolumn{2}{|c|}{4} \\
\hline & $n$ & $\%$ & $n$ & $\%$ & $n$ & $\%$ & $\mathrm{n}$ & $\%$ & $n$ & $\%$ \\
\hline 1 & 2 & 1,67 & 46 & 38,33 & 72 & 60 & 0 & 0 & 0 & 0 \\
\hline 2 & 0 & 0 & 50 & 42,02 & 69 & 57,98 & 0 & 0 & 0 & 0 \\
\hline 3 & 12 & 10,17 & 85 & 72,03 & 21 & 17,80 & 0 & 0 & 0 & 0 \\
\hline
\end{tabular}

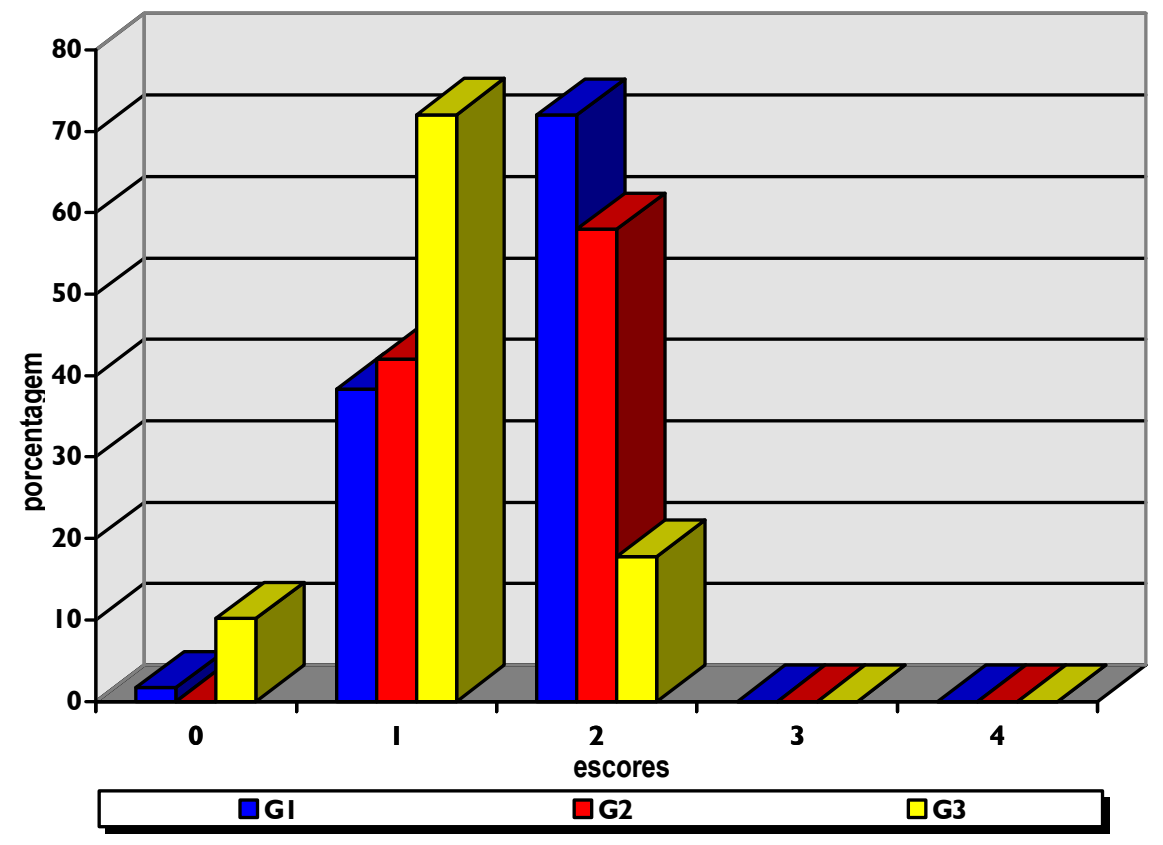

FIGURA 5.4 Comparação da quantidade de reabsorção encontrada nos dentes inferiores, nos 3 grupos estudados $(n=357)$ 
Constatou se então, que o grupo 3, apresentou maior diferença em relação aos grupos 1 e 2, no arco inferior, no qual 10,17\% dos dentes não foram reabsorvidos (grau 0), 72,03\% apresentaram reabsorção leve (grau 1) e apenas $17,80 \%$ apresentaram reabsorção moderada (grau 2), ao contrário do grupo 1, no qual apenas 1,67\% não apresentaram reabsorção (grau 0), 38,33\% apresentaram somente reabsorção leve (grau 1) e a maioria, (60\%), apresentou reabsorção moderada (grau 2) e do grupo 2, no qual $42,02 \%$ apresentaram reabsorção leve (grau 1) e 57,98\% apresentaram reabsorção moderada (grau 2).

$\mathrm{Na}$ análise da quantidade de reabsorção encontrada dentro do grupo 3, entre os pacientes tratados na clínica de Pós Graduação da FOB $^{*}$ e na clínica particular**, os resultados indicaram que o subgrupo de pacientes tratados na clínica particular apresentou menos reabsorção do que os pacientes tratados na FOB (Tabela 5.6/Figura 5.5).

TABELA 5.6 - Comparação da quantidade de reabsorção encontrada, no grupo 3, entre os pacientes tratados na FOB e na clínica particular (teste de Mann Whitney)

$\mathrm{U}=4913$

$\mathrm{U}^{\prime}=4798$

$(p=0,0019)$

\begin{tabular}{ccc}
\hline \hline & FOB & CLÍNICA PARTICULAR \\
\hline \hline POSTO MÉDIO & 76 & 42 \\
\hline MEDIANA & 45 & 35,5 \\
\hline
\end{tabular}

* pacientes do número B1 ao B19

** pacientes do número B20 ao B30 


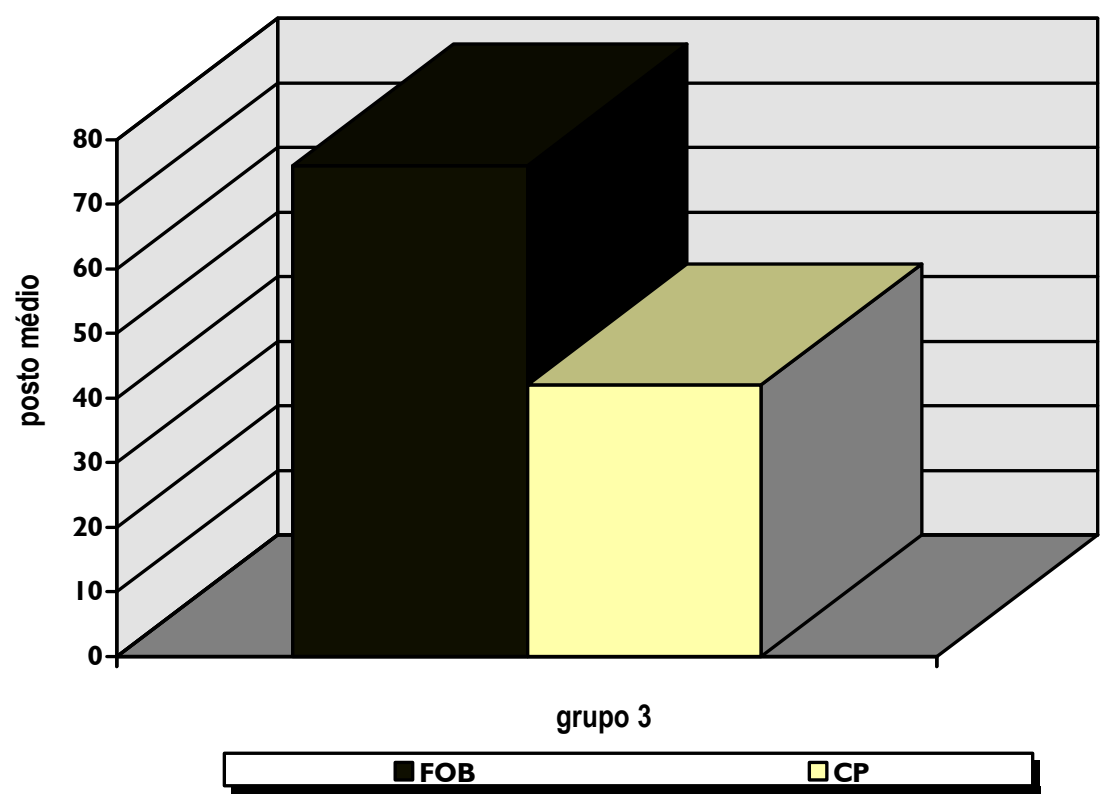

FIGURA 5.5 Comparação da quantidade de reabsorção encontrada no grupo 3, entre os pacientes tratados na FOB e os tratados na clínica particular (CP)

Como houve diferença entre os 2 subgrupos, decidiu se comparar os outros 2 grupos (1 e 2) com o subgrupo tratado na FOB, pelo teste de Kruskal Wallis. Nesta comparação, verificou se que os primeiros apresentaram mais reabsorção em relação ao subgrupo da FOB (Tabela 5.7/Figura 5.6).

TABELA 5.7 - $\quad$ Comparação da quantidade de reabsorção nos 3 grupos, utilizando o subgrupo tratado na FOB (teste de Kruskal Wallis)

$\mathrm{T}=18,28(p=0,001)$

\begin{tabular}{ccc}
\hline \hline GRUPOS & POSTO MÉDIO $(p<0,01)$ \\
\hline \hline 1 & 161 & 160,5 \\
\hline 2 & 116,5 \\
\hline 3 (Subgrupo FOB)
\end{tabular}




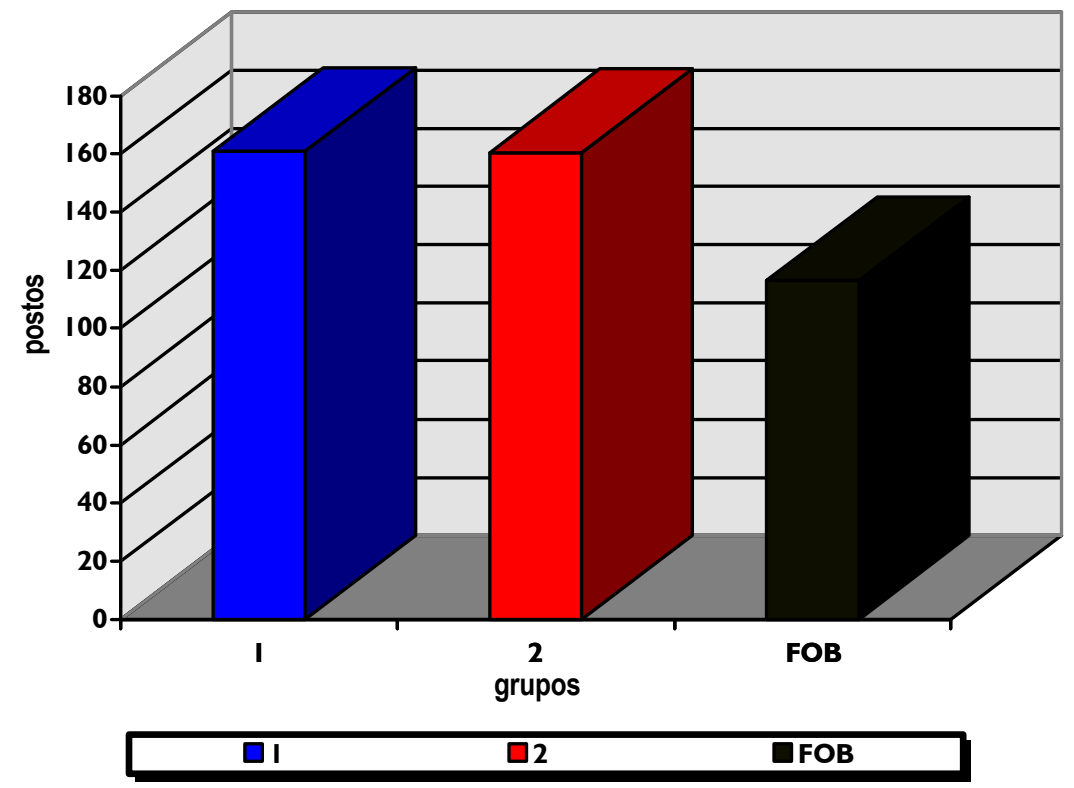

FIGURA 5.6 Comparação da quantidade de reabsorção entre os grupos 1 e 2 e o subgrupo FOB

- Tempo de tratamento e a quantidade de extrações (avaliação complementar)

O tempo de tratamento e a quantidade de extrações realizadas em cada grupo foram comparados pela análise de variância (Tabela $5.8)$.

TABELA 5.8 C Comparação entre os 3 grupos, em relação ao tempo de tratamento e à quantidade de extrações (Análise de variância Teste F)

\begin{tabular}{ccc}
\hline \hline VARIÁVEL & VALOR DE F & $p$ \\
\hline \hline TEMPO DE TRATAMENTO & 14,10 & $<0,0001$ \\
QUANTIDADE DE EXTRAÇÕES & 0,898 & $\mathrm{~ns}$ \\
\hline
\end{tabular}


Em relação ao tempo, o grupo 1 apresentou maior tempo de tratamento do que os grupos 2 e 3 , os quais foram equivalentes entre si (Tabela 5.9/Figura 5.7).

TABELA 5.9 Comparações individuais (teste de Scheffé)

Valor crítico: 2,49

\begin{tabular}{cc|c}
\hline \hline GRUPOS & TEMPO MÉDIO (MESES) \\
\hline \hline 1 & 29,13 & \\
\hline 2 & 19,26 & \\
\hline 3 & 18,93 & \\
\hline
\end{tabular}

estatisticamente equivalentes

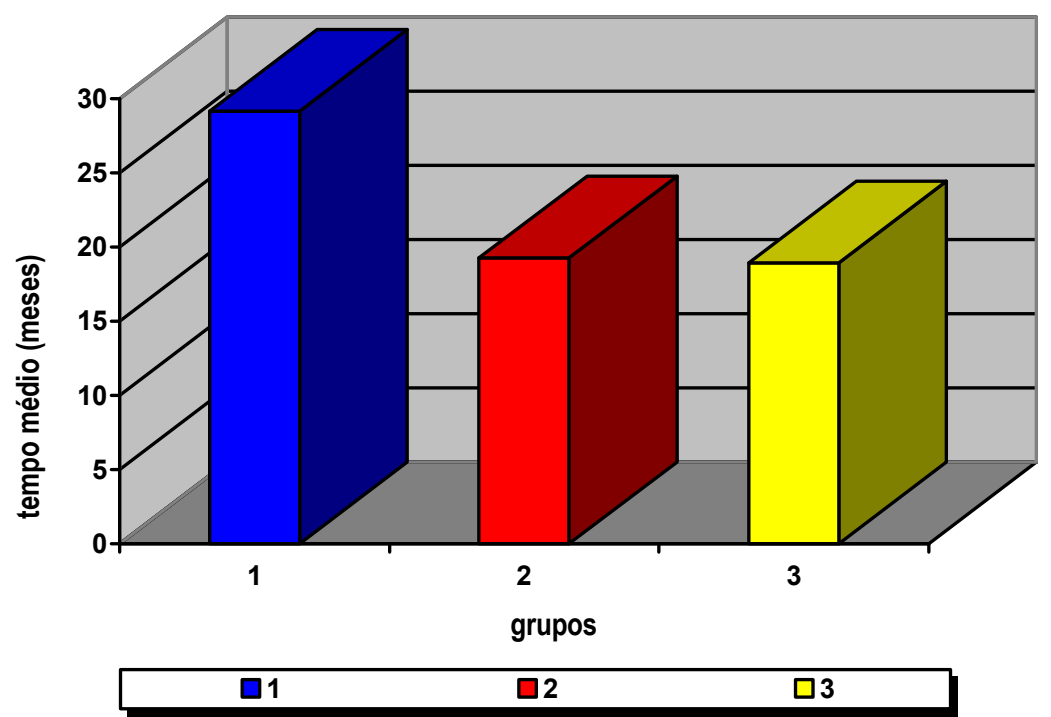

FIGURA 5.7 Comparação do tempo de tratamento nos 3 grupos 
A quantidade de extrações realizadas não diferiu entre os grupos. No grupo 1 foram extraídos, em média, 1,79 dentes; no grupo 2, 2,06, enquanto que no grupo 3, a média de extrações foi de 2,43 (Tabela 5.10/Figura 5.8). Observa se aqui, que o grupo 3 sofreu o maior número de extrações, embora essa diferença não tenha sido estatisticamente significante.

TABELA 5.10 Quantidade de extrações realizadas, em média, em cada grupo

\begin{tabular}{ccc}
\hline \hline GRUPOS & $\mathbf{N}^{\circ}$ DE EXTRAÇÕES & DESVIO PADRÃO \\
\hline \hline 1 & 1,79 & 1,93 \\
\hline 2 & 2,06 & 1,85 \\
\hline 3 & 2,43 & 1,73 \\
\hline
\end{tabular}

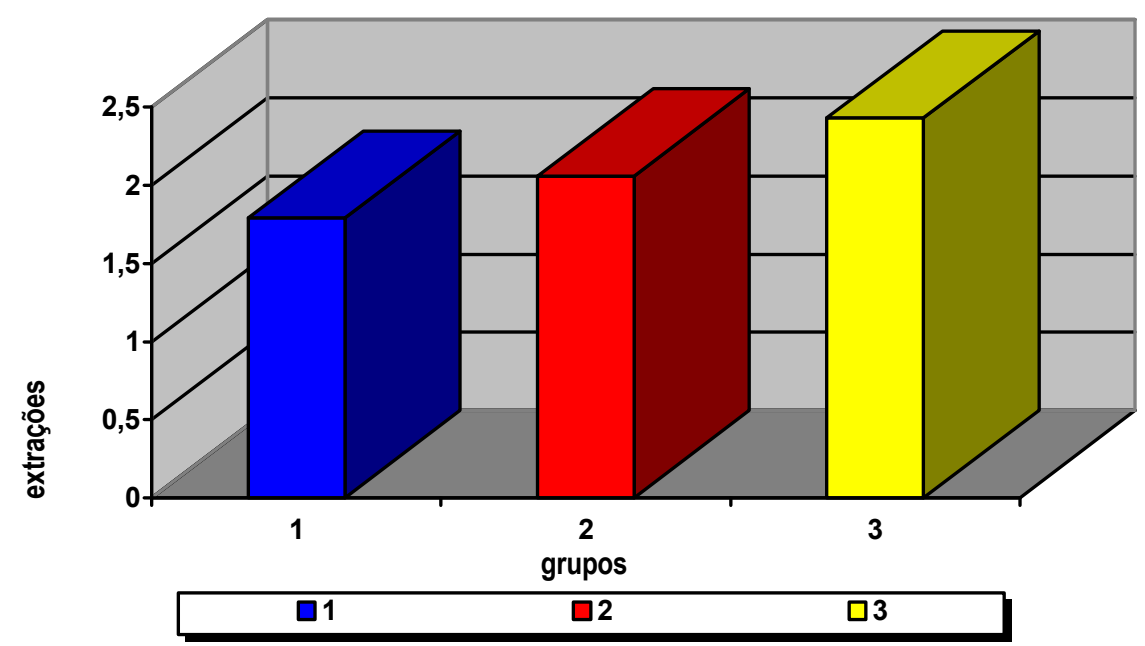

FIGURA 5.8 Comparação da quantidade de extrações nos 3 grupos 


\subsection{QUANTIDADE DE REABSORÇÃO RADICULAR DECORRENTE DO TRATAMENTO ORTODÔNTICO}

Nos 90 casos pertencentes à amostra, setecentos e doze (712) dentes foram analisados: trezentos e cinqüenta e cinco (355) na maxila e 357 na mandíbula. Do total dos dentes examinados, dezesseis $(2,25 \%)$ não apresentaram comprometimento radicular (grau 0), trezentos e três $(42,56 \%)$ apresentaram apenas reabsorção leve (grau 1), trezentos e oitenta $(53,37 \%)$ apresentaram reabsorção moderada (grau 2), dez (1,40\%), reabsorção acentuada (grau 3) e somente três $(0,42 \%)$ apresentaram reabsorção extrema (grau 4) (Figura 5.9).

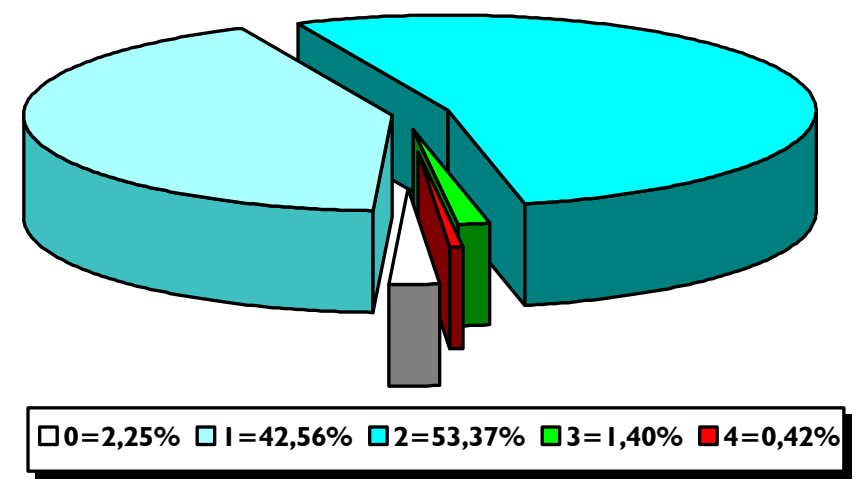

FIGURA 5.9 $\quad$ Porcentagem de reabsorção encontrada, em relação ao número de dentes $(n=712)$

Considerando se a reabsorção encontrada, em relação ao número de pacientes, verificou se que a maioria dos pacientes $(91,11 \%)$ apresentou uma quantidade de reabsorção, variando apenas entre leve e moderada, apenas 5 (5,55\%) mostraram reabsorção acentuada (grau 3) em ao menos 1 de seus dentes (não apresentando reabsorção extrema em nenhum) e 
apenas 3 pacientes $(3,33 \%)$ apresentaram reabsorção extrema (grau 4) em pelo menos 1 de seus dentes (Tabela 5.11/Figura 5.10).

TABELA 5.11 Porcentagem de pacientes que apresentaram reabsorção leve, moderada, acentuada e extrema

\begin{tabular}{cc}
\hline \hline REABSORÇÃO & $\%$ \\
\hline \hline LEVE, MODERADA & 91,11 \\
\hline ACENTUADA & 5,55 \\
\hline EXTREMA & 3,33 \\
\hline
\end{tabular}

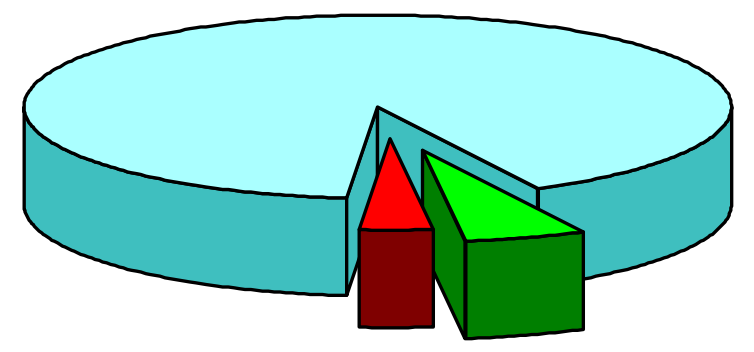

$\square I, 2=91,11 \% \quad \square 3=5,55 \% \quad \square 4=3,33 \%$

FIGURA 5.10 Porcentagem de reabsorção encontrada $(1,2$ = reabsorção variando de leve a moderada; 3 = reabsorção acentuada; 4 = reabsorção extrema), em relação ao número de pacientes estudados $(n=90)$ 


\subsection{PREVALÊNCIA DE REABSORÇÃO NOS INCISIVOS}

\section{$\Rightarrow$ GRUPO 1:}

Não houve, do ponto de vista estatístico, maior reabsorção média para um determinado dente. Numericamente os maiores valores foram observados no incisivo lateral superior esquerdo (22) e no incisivo central inferior direito (41) e a menor reabsorção aconteceu nos incisivos laterais inferiores (32 e 42) (Tabela 5.12).

- Comparação da reabsorção média por tipo de dente, para o grupo 1 (teste de Kruskal Wallis):

$\mathrm{T}=9,657(\mathrm{n} \sim \mathrm{s})$

$\Rightarrow$ GRUPO 2:

O incisivo central superior direito (11) apresentou a maior reabsorção, enquanto que os incisivos laterais inferiores (42 e 32) apresentaram menos reabsorção que os demais (Tabela 5.12).

- Comparação da reabsorção média por tipo de dente, para o grupo 2 (teste de Kruskal Wallis):

$\mathrm{T}=17,02 \quad(p=0,0045)$

$\Rightarrow$ GRUPO 3

Numericamente, o incisivo central superior esquerdo (21) apresentou maior reabsorção. Os incisivos laterais inferiores (32 e 42), equivalentes entre si, apresentaram menor reabsorção do que os outros dentes (Tabela 5.12).

- Comparação da reabsorção média por tipo de dente, para o grupo 3 (teste de Kruskal Wallis):

$\mathrm{T}=56,91(\mathrm{p}<0,0001)$ 
cada incisivo.

A Figura 5.11 mostra a prevalência de reabsorção em

TABELA 5.12 - $\quad$ Escores médios de reabsorção, para cada incisivo, nos grupos 1, 2 e 3

\begin{tabular}{c|cc|ccc|cc|cc}
\hline \hline \multirow{2}{*}{ GRUPOS } & \multicolumn{10}{|c|}{ DENTES } \\
\cline { 2 - 10 } & 11 & 21 & 12 & 22 & 41 & 31 & 42 & 32 \\
\hline \hline 1 & 1,7 & 1,77 & 1,65 & 1,8 & 1,8 & 1,7 & 1,4 & 1,43 \\
\hline 2 & 1,86 & 1,7 & 1,7 & 1,67 & 1,76 & 1,73 & 1,35 & 1,46 \\
\hline 3 & 1,51 & 1,69 & 1,51 & 1,48 & 1,36 & 1,10 & 1,0 & 0,86 \\
\hline TOTAL & \multicolumn{2}{|c|}{1,70} & \multicolumn{2}{|c|}{1,64} & \multicolumn{2}{c}{1,57} & \multicolumn{2}{c}{1,25} \\
\hline
\end{tabular}

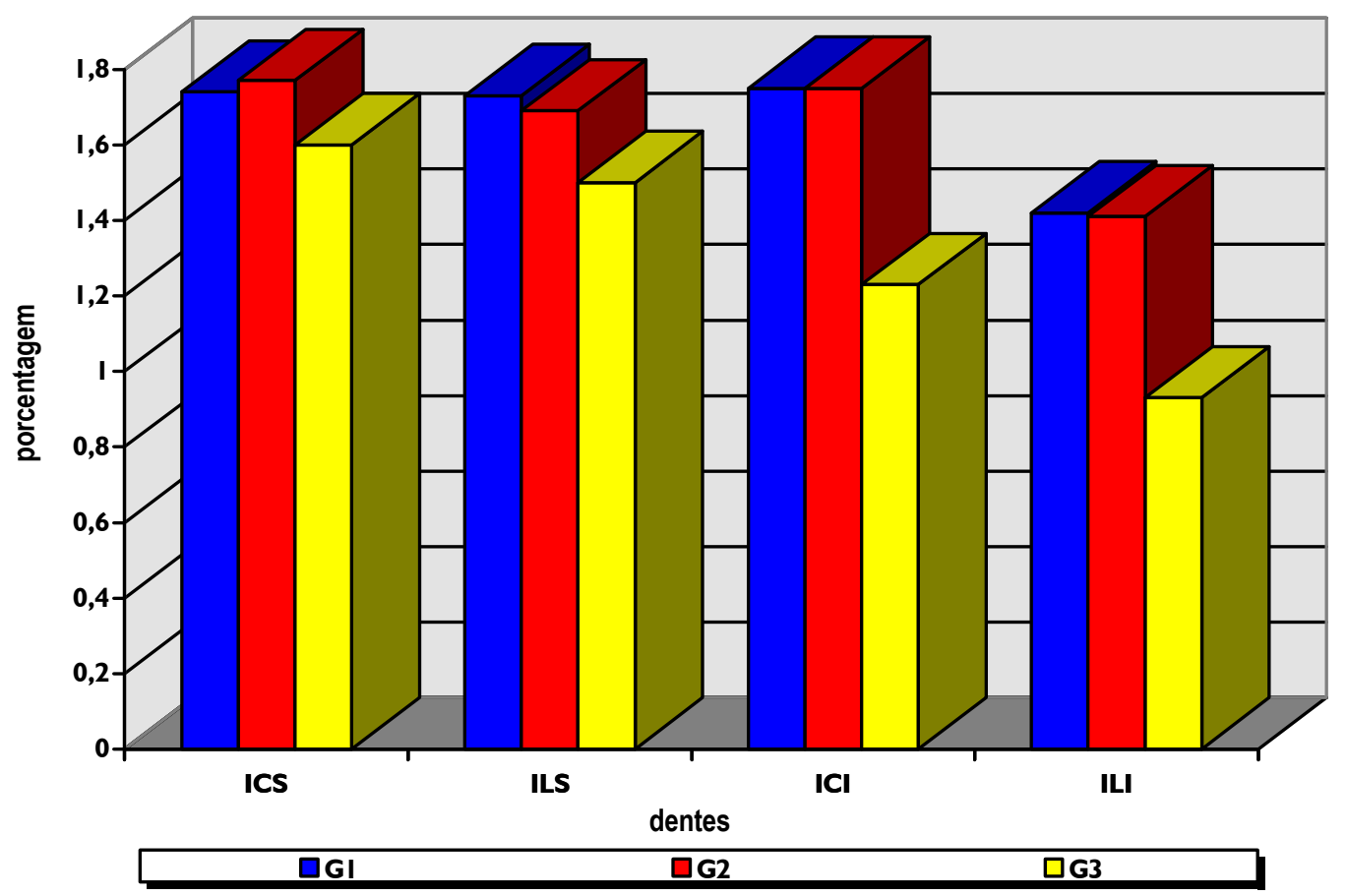

FIGURA 5.11 Escores médios de reabsorção para cada incisivo, considerando se os grupos individualmente (ICS = incisivo central superior; ILS = incisivo lateral superior; ICI = incisivo central inferior; ILI = incisivo lateral inferior) 
De modo geral, pôde se observar que os dentes mais reabsorvidos foram os incisivos centrais superiores, seguidos dos laterais superiores, incisivos centrais inferiores e, por último, os incisivos laterais inferiores (Tabela 5.12/Figura 5.12).

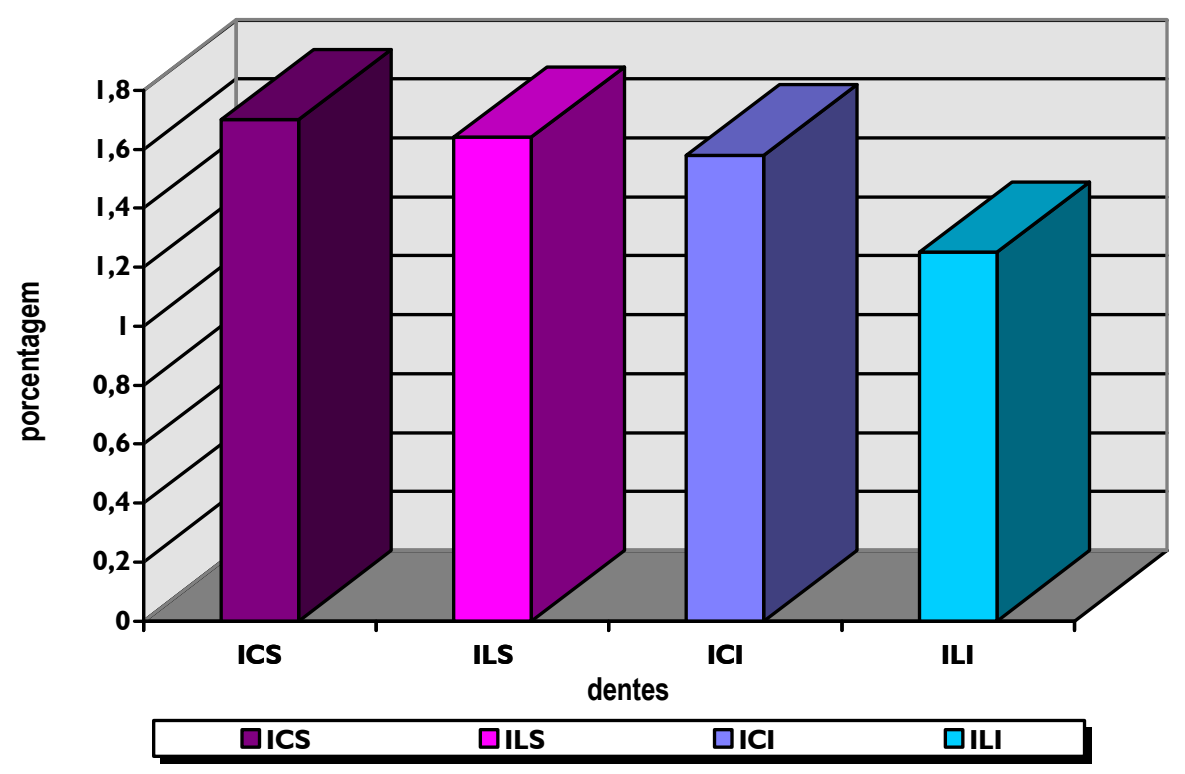

FIGURA 5.12 - Escores médios de reabsorção para cada incisivo, considerando se os 3 grupos estudados (ICS = incisivo central superior; ILS = incisivo lateral superior; ICI = incisivo central inferior; ILI = incisivo lateral inferior) 


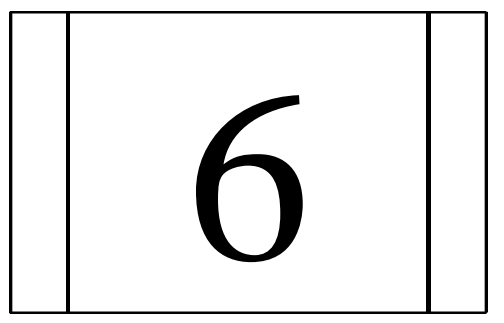

DISCUSSÃO 


\section{DISCUSSÃO}

Na revisão da extensa literatura disponivel sobre o assunto, verifica-se a polêmica existente em relação ao tema estudado. Todavia, existe um ponto de vista comum a todos os autores: infelizmente a reabsorção radicular apical, decorrente do tratamento ortodôntico, constitui um efeito extremamente freqüente. Apesar disso, não se pode considerar que essa seja uma reação "normal" do periodonto, frente à aplicação de forças, já que é conhecido por todos que a reabsorção radicular de dentes permanentes, diferentemente daquela que ocorre nos dentes decíduos, sempre é patológica.

Embora existam muitas publicações sobre reabsorção óssea subseqüente à aplicação de força, poucos trabalhos preocupam-se em descrever o desenvolvimento do processo de reabsorção radicular subseqüente à movimentação dentária. Na realidade, as pesquisas encontradas tratam apenas de "partes" do processo. Algumas abordam o processo inflamatório, outras, apenas o processo de reparo.

Apesar da vital importância do assunto, não existe uma publicação que descreva com clareza como o processo de reabsorção se desenvolve, desde o momento da aplicação da força até o reparo. Por esse motivo, julgou-se necessário abordar, de maneira simples, no entanto detalhada, esse tema tão complexo. Além disso, serão discutidos, neste capítulo ainda, o método utilizado e a significância dos resultados obtidos. 


\subsection{ASPECTOS BIOLÓGICOS}

Basicamente, pode-se afirmar que a aplicação de força leva à reação inflamatória e à lesão dos tecidos. O que caracteriza o processo inflamatório, nas fases iniciais, é a reação dos vasos sangüíneos, levando ao acúmulo de líquidos e de células sangüineas. As respostas vasculares e celulares da inflamação são mediadas por fatores químicos oriundos do plasma e das células. Uma série de mediadores, agindo juntos ou em seqüência, influencia a evolução da resposta inflamatória. A agressão causa esse tipo de resposta, porém, as substâncias químicas liberadas é que a medeiam ${ }^{39}$.

Muito pouco se conhecia sobre o que acontece nas primeiras horas após ser aplicada e mantida uma força no dente. Contudo, experimentos recentes têm mostrado que o nivel de prostaglandina* aumenta no ligamento periodontal, em um curto espaço de tempo, após a aplicação da força e atualmente parece claro que a prostaglandina E constitui um importante mediador da resposta celular no processo inflamatório. Há evidências de que a prostaglandina é liberada quando as células são deformadas mecanicamente 28,104 .

Outros mediadores químicos, particularmente os membros da família das citocinas são também envolvidos no processo de movimentação dentária $26,27,104,110$. Considerando-se que as drogas de vários tipos podem afetar tanto o nível de prostaglandinas como o de outros mediadores químicos em potencial, torna-se claro que, no futuro, será possivel o uso de agentes farmacológicos para induzir ou suprimir o movimento dentário, como parte do tratamento ortodôntico ${ }^{104,110}$. Há evidências de que agentes farmacológicos utilizados no controle da dor

* As prostaglandinas são lipídeos solúveis, os quais ligam-se a receptores de superficie. Elas modulam as resposta de alguns hormônios, apresentam efeitos em muitos processos celulares e participam do desenvolvimento da inflamação. A prostaglandina E apresenta ainda, a interessante propriedade de estimular tanto a atividade osteoclástica quanto à osteoblástica fazendo isto como um mediador do movimento dentário ${ }^{110}$. No corpo humano, elas são formadas a partir do ácido araquidônico, que por sua vez, é derivado dos fosfolipídeos da membrana celular ${ }^{104,110}$. 
também podem influenciar a atividade celular, vital para a remodelação dos tecidos de suporte ${ }^{110}$.

Sabe-se que quando a força ortodôntica é aplicada, cada movimento pode resultar em estresse celular, alterando o influxo do cálcio e outros íons. Parece que as forças ortodônticas podem ativar os sistemas nervoso e imune. A vasodilatação leva à migração de macrófagos e de outras células do processo inflamatório, além de proteínas e fluidos, para o espaço extracelular, liberando citocinas. Estas atraem os leucócitos e estimulam a proliferação de fibroblastos ${ }^{110}$.

A maioria das reabsorções radiculares ocorridas durante o tratamento ortodôntico está relacionada à injúria local, ao ligamento periodontal e, em particular, à associação com o processo de necrose asséptica, tradicionalmente denominado hialinização. A superfície radicular parece estar protegida por uma barreira. Mesmo os tecidos não ou parcialmente mineralizados (osteóide e cementóide) são reabsorvidos com dificuldade. O cementóide (pré-cemento não-mineralizado) e suas células têm sido relacionados com a alta resistência à reabsorção das superficies radiculares, agindo como uma superficie de revestimento ${ }^{29}$. Tem sido sugerido que os restos epiteliais de Malassez são um fator de proteção da superficie radicular, contudo, o dano a essas células, durante a compressão do ligamento periodontal, pela pressão contínua, pode inibir essa capacidade protetora ${ }^{31}$.

Publicações recentes indicam que a reabsorção dos tecidos dentinários mineralizados tem início quando os osteoclastos conseguem acesso aos tecidos mineralizados por uma lesão na camada das células germinativas que recobrem o tecido ${ }^{63,133,139}$, quando o pré-cemento é lesado mecanicamente ${ }^{133}$. 
A reabsorção radicular não se inicia no centro da zona hialinizada, mas na periferia, onde as células viáveis ainda existem. Hoje, sabe-se que as primeiras células a penetrarem no pré-cemento não são os clastos. Duas condições são necessárias para que a reabsorção ocorra: dano na barreira do pré-cemento e presença de células viáveis, disponiveis para invadir e remover o tecido necrótico que cobre a superficie. A espessura da camada de tecido necrótico parece decidir quando inicia o primeiro ataque. O evento seguinte é a fagocitose dos remanescentes celulares e conjuntivo por macrófagos e fibroblastos 29 . A população de macrófagos envolvidos na remoção de tecido necrótico no ligamento periodontal opera em conjunto com muitos estimuladores e aceleradores da reabsorção: neurotransmissores, citocinas, prostaglandinas, entre outros ${ }^{31}$. Os macrófagos, presentes no processo inflamatório ${ }^{39}$, são responsáveis pelo reconhecimento da proteína estranha (matriz dentinária exposta), após o dano no pré-cemento. A perda do précemento, com conseqüente exposição de tecido mineralizado, é que atrai os clastos $^{29}$.

A deformação mecânica do ligamento periodontal induz uma resposta lenta e o aparecimento do primeiro osteoclasto pode demorar até 48 horas. Estudos de cinética celular indicam que eles apresentam 2 origens distintas: alguns podem ser derivados de uma população celular local, enquanto outros são trazidos de áreas distantes, via fluxo sangüíneo. Ao mesmo tempo, porém um pouco mais atrasados, chegam os osteoblastos, que são recrutados localmente das células progenitoras no ligamento periodontal ${ }^{104}$.

O modo como os osteoblastos regulam a atividade clástica ainda é pobremente entendido ${ }^{89,29}$. No entanto, estudos recentes sugerem dois mecanismos interrelacionados: 
- Os blastos podem promover a reabsorção indiretamente, pela degradação de tecido não mineralizado;

- Os blastos podem produzir uma pequena quantidade de mediadores, os quais ativam diretamente os clastos ${ }^{29}$.

Sabe-se que os osteoblastos contêm receptores para a maioria dos agentes reabsorvedores, reconhecendo e transmitindo aos clastos o comando para realizarem a reabsorção ${ }^{36,87}$. Os osteoclastos são responsáveis tanto pela desmineralização do tecido, como pela degradação da matriz orgânica após a desmineralização63,118. Os clastos com borda em escova são vistos somente em contato com as lacunas de reabsorção, usualmente adjacentes à superfície dentinária reabsorvida ${ }^{30}$.

Os clastos, agora ativos, apresentam invaginações em sua superficie, conhecidas com "bordas em escova" e estes, aderem firmemente às proteínas do citoesqueleto e da membrana, fagocitando e reprocessando as micropartículas de matriz mineralizada e desmineralizada. Liberam, então, alguns íons e aminoácidos na superfície externa, tornando o $\mathrm{pH}$ ácido. Quando o meio torna-se hipersaturado de íons cálcio, há uma abertura da ligação dos clastos com a matriz e o conteúdo do clasto é extravasado. Este fecha-se e reinicia o processo, levantando uma parte de sua membrana, girando e mudando de posição, formando um desenho semicircular, que é representado pelas superfícies irregulares e pontiagudas vistas na radiografia. Com os movimentos de intrusão e extrusão do dente no alvéolo, uma microlesão forma-se no tecido periodontal, provocando ou exacerbando a inflamação, tendendo a uma regularização do ápice, promovendo a reabsorção e a diminuição do comprimento radicular* . 
A remoção da força faz com que os osteoclastos cedam lugar aos osteoblastos, induzindo o reparo, descrito pela migração de cementoblastos sobre a superficie reabsorvida, competindo pela superficie disponivel e excluindo os osteoblastos e os clastos63. As lacunas de reabsorção, que já podem ser observadas microscopicamente depois de 7 dias de aplicação de força ${ }^{44}$, são geralmente cobertas por um tecido fibroso, no qual uma camada de cemento secundário será formada na superficie radicular reabsorvida ${ }^{110}$. Um novo cemento mineralizado já pode ser observado, na superficie radicular, após 21 dias ${ }^{32}$, no entanto, também é conhecido que o processo de reabsorção radicular, subseqüente à movimentação dentária, continua somente após um curto período (5 a 6 semanas), depois da remoção da força ${ }^{38}$. O reparo funcional, com a superficie total das cavidades de reabsorção revestidas por cemento, pode ocorrer após 5 a 8 semanas $^{97}$.

\subsection{CONSIDERAÇÕES RELACIONADAS À AMOSTRA E AO MÉTODO}

Em uma amostra constituída de pacientes tratados por diferentes profissionais, muitas variáveis devem ser consideradas. No entanto, é muito difícil conseguir uma amostra de tamanho considerável para realizar uma pesquisa desse tipo. Mais dificil ainda seria encontrar 90 pacientes tratados por um único operador, com 3 técnicas diferentes. Principalmente se for levado em consideração que a Terapia Bioeficiente é uma técnica extremamente nova, apresentada à literatura em janeiro de 1995135,136. Seria praticamente impossivel esperar que um único profissional possuísse 30 casos concluídos, tratados com essa técnica e mais 60 casos para comparação, tratados com a técnica do Arco de Canto Simplificada e do Arco Reto. Em pesquisa, pode-se visar a perfeição, porém a adequação constitui o padrão na maioria das vezes utilizado69. 
Além disso, existem outros trabalhos na literatura realizados com amostras de diferentes procedências $19,49,92,101,111,137$, que não ressaltam que esse fator pode interferir nos resultados obtidos.

A opção de eliminar da amostra os pacientes com dentes com tratamento endodôntico, previamente ao tratamento, foi baseada no fato de que os graus de reabsorção diferem em dentes vitais e naqueles tratados endodonticamente ${ }^{125,140}$, apesar de ainda não estar totalmente clara a relação entre o tratamento endodôntico e a movimentação dentária. WICKWIRE et al. ${ }^{140}$, em 1974, verificaram que os dentes tratados endodonticamente são mais suscetiveis à reabsorção, quando movimentados. Diferentemente, SPURRIER et al.125, em 1990, encontraram menos reabsorção nos dentes tratados endodonticamente, quando comparados aos dentes vitais, após a movimentação dentária. Dentes com tratamento endodôntico poderiam, portanto, constituir uma variável, com respostas imprevisiveis, dificultando a interpretação dos resultados.

Os pacientes com reabsorção previamente ao tratamento (3 tratados com Arco de Canto Simplificada, 2, com Arco Reto e 2, com a Terapia Bioeficiente) foram eliminados porque dois estudos realizados por MASSLER; MALONE94 e GOLDSON; HENRIKSON50 comprovaram que pacientes com reabsorção radicular prévia ao tratamento apresentam grande reabsorção radicular após o término do mesmo. GOLDSON; HENRIKSON50 mostraram que a incidência de reabsorção pode aumentar de $4 \%$, ao início do tratamento, para até $77 \%$ ao término do mesmo.

Os grupos de pacientes selecionados apresentavam, ainda, idade média compativel, eliminando possiveis influências da idade na quantidade de reabsorção encontrada. LINGE; LINGE79 afirmaram que 
a limitação da idade reduz o problema de crescimento residual, o que poderia interferir na quantidade de reabsorção e homogeneizar as circunstâncias do tratamento.

O método radiográfico escolhido - de radiografias periapicais - constitui o método de eleição para o estudo da reabsorção radicular apical e por isso é utilizado pela maioria dos autores $24,35,41,53$, $55,67,76,77,78,79,81,83,92,93,112,114,122,125,137$ (Tabela 6.1). As radiografias periapicais são muito superiores às panorâmicas, oclusais e cefalométricas laterais, para o estudo de estruturas radiculares, principalmente quando obtidas com a técnica do paralelismo $3,4,47,74,86$. Esta técnica fornece informações mais apropriadas; oferece a menor radiação ao paciente, quando utilizada nos dentes que comumente apresentam maior encurtamento, ou seja, os incisivos superiores e inferiores; provoca menor distorção e os erros de superposição também são menores, quando comparada às radiografias panorâmicas e cefalométricas. Com o uso da técnica do paralelismo, há menor absorção de radiação pelos tecidos radiossensiveis da cabeça e do pescoço, em comparação com a técnica periapical da bissetriz, com a radiografia panorâmica e com a cefalométrica. Isso é especialmente importante em crianças, adolescentes e adultos jovens, os quais são mais radiossensiveis que os adultos, em função do rápido crescimento dos órgãos, da posição da tireóide e do maior tempo para os efeitos da radiação tornarem-se aparentes ${ }^{74,132}$.

O processamento do filme, por meio de processadora automática permitiu que o tempo de revelação e fixação fossem padronizados, o que proporcionou uma radiografia com densidade, contraste e, conseqüentemente, nitidez semelhantes.

O método que classifica a reabsorção por escores, proposto por LEVANDER; MALMGREN76, embora subjetivo, é utilizado com 
freqüência no estudo da reabsorção radicular subseqüente à movimentação dentária. Sua principal vantagem é o fato de não depender da padronização da radiografia inicial. Diversos autores utilizaram esse método, ou outro semelhante $\mathrm{1}^{1,15,20,35,42,52,53,55,65,76,81,83,92,101,103,111,112,122,123,137}$. Além disso, os erros inter e intra-examinadores, neste estudo, demonstraram excelente nivel de concordância, reduzindo a possibilidade de erro. BLAKE; WOODSIDE; PHAROAH ${ }^{24}$ não concordam com esse método e, como outros, quantificaram a reabsorção por meio da comparação das medidas realizadas nas radiografias pré e pós -tratamento $19,38,41,48,54,56,73,78,79,85,125,130$.

TABELA 6.1 - Métodos radiográficos utilizados por diversos autores, no estudo da reabsorção radicular

\begin{tabular}{|c|c|}
\hline RADIOGRAFIAS & AUTORES \\
\hline PERIAPICAL & $\begin{array}{l}\text { KETCHAM }^{67} \text { / RUDOLPH }{ }^{114} \text { / HEMLEY } 55 \text { / VONDERAHE }{ }^{137} \text { / NEWMAN92 / RONNERMAN; } \\
\text { LARSSON } 112 \text { / CANSANÇÃO }^{35} \text { / ODENRICK; BRATTSTROM93 / LINGE; LINGE78 / DERMAUT; } \\
\text { DERMUNCK }{ }^{41} \text { / SHARPE et al.122 / MALMGREN et al.81 / LEVANDER; MALMGREN76 / SPURRIER et } \\
\text { al. }{ }^{125} \text { / LINGE; LINGE79 / HARRIS; BUTLER53 / MARTINS; CANSANÇÃO; SANCHEZ }{ }^{83} \text { / LEVANDER; } \\
\text { MALMGREN; ELIASSON77 / BLAKE; WOODSIDE; PHAROAH }{ }^{24}\end{array}$ \\
\hline $\begin{array}{l}\text { PERIAPICAL+ } \\
\text { CEFALOMÉTRICA }\end{array}$ & $\begin{array}{l}\text { PHILLIPS }{ }^{101} \text { / DESHILDS }{ }^{42} \text { / ARNESEN15 / MCFADEN85 / MIRABELLA; ARTUN88 / BAUMERIND; } \\
\text { KORN; BOYD19 / TAITHOGCHAI; SOOKKORN; KILLIANY130 }\end{array}$ \\
\hline $\begin{array}{l}\text { PERIAPICAL+ } \\
\text { PANORÂMICA }\end{array}$ & AHLGREN ${ }^{1}$ \\
\hline $\begin{array}{c}\text { PERIAPICAL+ } \\
\text { PANORÂMICA+ } \\
\text { CEFALOMÉTRICA }\end{array}$ & BECK; HARRIS20 \\
\hline CEFALOMÉTRICA & PLETS et al. ${ }^{103}$ / COPELAND; GREEN ${ }^{39}$; GOLDIN ${ }^{49}$ \\
\hline PANORÂMICA & KALEY; PHILLIPS65 / HENDRIX et al. ${ }^{56}$ \\
\hline $\begin{array}{l}\text { PANORÂMICA+ } \\
\text { CEFALOMÉTRICA }\end{array}$ & HARRIS; BACKER ${ }^{52}$ / HARRIS; KINERET; TOLLEY54 \\
\hline $\begin{array}{l}\text { PANORÂMICA+ } \\
\text { OCLUSAL }\end{array}$ & ALEXANDER $^{2}$ \\
\hline
\end{tabular}




\subsection{INTERPRETAÇÃO DOS RESULTADOS OBTIDOS}

\subsubsection{Comparações entre os grupos}

\section{- Quantidade de reabsorção}

Comparando os graus de reabsorção encontrados nos 3 grupos estudados, verificou-se que o grupo 3 (Terapia Bioeficiente) apresentou menos reabsorção que os grupos 1 (Arco de Canto Simplificada) e 2 (Arco Reto), os quais foram equivalentes entre si (Tabela 5.2 / Figura 5.2).

$\mathrm{Na}$ realidade, o mais importante resultado desta pesquisa consistiu no fato da reabsorção radicular não ter sido mais acentuada nos pacientes tratados com a Terapia Bioeficiente. Poderia-se pensar que a introdução de um arco retangular, nos estágios iniciais do tratamento, levaria a uma maior reabsorção radicular. Contudo, verificouse que a menor quantidade de reabsorção encontrada no grupo tratado com a Terapia Bioeficiente constitui um fator positivo na biocompatibilidade dos novos materiais ortodônticos (fios e bráquetes).

Embora existam poucos estudos comparando técnicas que utilizam fios superelásticos, algumas considerações podem ser realizadas, em relação à menor reabsorção encontrada no grupo 3 .

MIURA89, em 1993, afirmou que a descoberta das propriedades superelásticas das ligas de NiTi e o seu papel na atividade osteoclástica constituem um marco científico na especialidade ortodôntica, estabelecendo um novo padrão biológico de tratamento.

VIAZIS 135,136, em 1995, ressaltou que os fios superelásticos promovem uma ação mais biológica, com menos desconforto para o paciente. A combinação de memória de forma, superelasticidade, 
força diferencial e dos íons nitrogênio*, na superfície desses fios, com o desenho dos bráquetes da Terapia Bioeficiente, torna o tratamento ortodôntico bastante confortável para o paciente, mesmo quando um fio retangular é inserido nas fases iniciais do tratamento. Já na técnica do Arco de Canto Simplificada, os fios redondos e retangulares, por serem de aço inoxidável, tendem a exercer uma força mais intensa, além de apresentarem grande atrito com os bráquetes ${ }^{62}$. Para que esse atrito seja superado, é necessário o emprego de força de retração de grande magnitude ${ }^{62}$, o que pode aumentar o risco de reabsorção e o deconforto do paciente ${ }^{135}$. Além disso, como a maioria das técnicas do Arco de Canto utiliza arco contínuo, o alinhamento dos dentes é realizado de forma indiscriminada, ou seja, o incisivo lateral, por exemplo, recebe a mesma força que o canino ${ }^{121}$. Já a série retangular de fios superelásticos termoativados Bioforce Ionguard ${ }^{* *}$ apresenta uma força de 80 gramas na região anterior e de 320 gramas na região posterior, movimentando os dentes sem sobrecarregá-los ${ }^{135,136}$.

Para permitir melhor adaptação de arcos de grandes diâmetros nas ranhuras do bráquetes, é necessária uma grande distância inter-ranhuras. Torna-se evidente, portanto, que um bráquete simples seria mais eficiente do que um duplo, apesar de não permitir um controle adequado da rotação e da angulação. Baseado nesses princípios, VIAZIS ${ }^{135,136}$ elaborou um novo sistema de bráquetes, com desenho inovador, que permite perfeita movimentação dentária pelo aumento do controle da angulação e da rotação. O bráquete utilizado na Terapia Bioeficiente, simples, proporciona um aumento da distância inter-ranhuras

\footnotetext{
* O processo de ionização da camada superficial dos fios Bioforce Ionguard reduz a média de força necessária para promover o deslizamento dos bráquetes ${ }^{72}$.

** GAC International Inc., NY
} 
e conseqüentemente possibilita um aumento do comprimento do fio e uma maior flexibilidade. QUINTANILLA et al.108, em 1995, comparando os bráquetes desenvolvidos por VIAZIS135,136 com outros disponiveis comercialmente (Roth, Shoulder, Synergy, Standard twin, Lang single), verificaram que os primeiros necessitam de uma força muito menor para promover a movimentação inicial. Em alguns casos (Viazis versus Lang single) essa diferença foi de até dez vezes. LAFERLA ${ }^{72}$, em 1996, comprovou que esses bráquetes apresentam menor resistência ao atrito, quando comparados a outros, como o Lewis, Elan, Minitwin, Twin, Spirit e Lumina. Verificou, ainda, que o desenho dos bráquetes da Terapia Bioeficiente facilita o deslizamento também em função da forma de amarração - os ombros permitem que as ligaduras elásticas fiquem distantes do arco, diminuindo a resistência ao deslizamento, diferentemente dos bráquetes convencionais, nos quais as ligaduras são firmemente amarradas, aumentando a resistência e dificultando a movimentação. Os bráquetes triangulares, associados aos fios superelásticos termoativados, parecem ter sido os responsáveis pela menor reabsorção radicular, decorrente do tratamento ortodôntico, encontrada no grupo 3 (Terapia Bioeficiente).

Outros acessórios podem também ter contribuído para a menor reabsorção encontrada no grupo tratado com a Terapia Bioeficiente. As molas utilizadas, superelásticas, apresentam propriedades não encontradas nas molas de aço inoxidável, proporcionando uma ativação mais rápida, eficiente e confortável. À temperatura corporal, exercem uma força constante de 150 gramas e são vantajosas porque promovem uma movimentação sem traumatismos nos tecidos moles e independem da colaboração do paciente ${ }^{135}$.

Após os resultados das comparações individuais, em função da grande diferença encontrada entre o grupo 3 e os demais, optou- 
se por analisar, separadamente, os graus de reabsorção encontrados nos dentes superiores e inferiores, com o objetivo de determinar em qual arco essa diferença foi maior (Tabela 5.4/Figura 5.3 e Tabela 5.5/Figura 5.4). Constatou-se, então, que o grupo 3, apesar de ter mostrado menos reabsorção em ambos os arcos, apresentou maior diferença, em relação aos grupos 1 e 2, nos incisivos inferiores, com 10,17\% dos dentes não reabsorvidos e $72,03 \%$ apresentando apenas um contorno irregular do ápice (grau 1), ao contrário dos grupos 1 e 2, nos quais a maioria (60 e $57,98 \%$, respectivamente) dos dentes apresentou reabsorção moderada (grau 2). A explicação para esse fato não foi encontrada na literatura.

Como alguns pacientes do grupo 3 foram tratados em uma clínica particular, para verificar o quanto isso influenciou nos resultados, optou-se por verificar se existiu diferença na quantidade de reabsorção encontrada dentro do grupo 3, entre os pacientes tratados na clinica particular e na clínica da FOB. Os resultados indicaram que o subgrupo da clínica particular apresentou menos reabsorção que os pacientes tratados na FOB (Tabela 5.6/Figura 5.5). Na comparação desses resultados, deve-se levar em conta a maior experiência clínica do profissional que tratou os pacientes em sua clinica privada (subgrupo $\mathrm{CP}$ ), em relação aos pacientes tratados pelos alunos dos cursos de PósGraduação e Especialização da FOB (subgrupo FOB). Vale ressaltar, no entanto, que no tratamento dos pacientes da FOB, com a Terapia Bioeficiente, 9 profissionais estiveram envolvidos. Deve-se lembrar aqui, que os alunos, de modo geral, provocam efeitos colaterais com maior freqüência que profissionais experientes.

Para verificar o quanto a constatação acima interferiu nos resultados, decidiu-se comparar os grupos 1 e 2 com o subgrupo FOB. Verificou-se, então, que mesmo os pacientes tratados na 
FOB, com a Terapia Bioeficiente, apresentaram menos reabsorção que os demais (embora agora a diferença tenha sido menor) (Tabela 5.7/Figura 5.6). O subgrupo tratado na FOB, formado por apenas 19 pacientes, apesar de menos representativo estatisticamente, fornece uma idéia mais precisa da diferença na quantidade de reabsorção entre os grupos e reafirma a maior compatibilidade biológica da Terapia Bioeficiente.

\section{- Tempo de tratamento}

Comparando o tempo de tratamento entre os grupos, verificou-se que os pacientes do grupo 1 (Arco de Canto Simplificada) foram tratados por um tempo significantemente maior que os pacientes dos grupos 2 (Arco Reto) e 3 (Terapia Bioeficiente), os quais foram equivalentes entre si (Tabela 5.9/Figura 5.7). O maior tempo necessário para tratar os pacientes do grupo 1 (Arco de Canto Simplificada), em relação aos outros 2 grupos, pode estar relacionado ao fato destes últimos serem pré-ajustados, diferentemente do primeiro. As técnicas que utilizam bráquetes pré-ajustados apresentam menor necessidade de dobras nos fios e, conseqüentemente, as variáveis também são minimizadas ${ }^{11,12}$. Os bráquetes guiam os dentes em vetores diretos, diminuindo os movimentos pendulares e outros movimentos desnecessários ${ }^{11,12}$. Isto pode ter caracterizado o menor tempo de tratamento encontrado nos grupos 2 e 3 . Os tempos médios de tratamento, relatados na literatura 38,42,52,55,65,76,77,79,85,88,103,111,122,123, variam bastante, de 19,5 a 43,3 meses (Tabela 6.2). No entanto, nenhum trabalho apresentou um tempo médio tão reduzido quanto o encontrado neste trabalho, para os pacientes tratados com a Terapia Bioeficiente $(18,93$ meses).

$\mathrm{Na}$ Terapia Bioeficiente, o clínico não precisa se preocupar em trocar os fios tão freqüentemente. Os fios retangulares, 
utilizados nas fases iniciais do tratamento, apresentam maiores vantagens, em relação aos redondos, por apresentarem melhor adaptação aos bráquetes, propiciando um melhor controle da posição radicular. A utilização de fios retangulares superelásticos, nas fases iniciais, permite ainda a sua inserção em todos os bráquetes para a correção das rotações, alinhamento, nivelamento e fechamento de espaços. Portanto, as 3 fases iniciais da terapia ortodôntica (alinhamento, nivelamento e fechamento de espaços) são abordadas como a primeira etapa do tratamento e a finalização, como a segunda etapa. Essa divisão do tratamento em duas etapas faz com que o ortodontista gaste o mesmo tempo na finalização de um caso, que na primeira etapa, podendo diminuir, assim, o tempo total de tratamento.

Pelos motivod anteriormente mencionados, ou seja, a divisão do tratamento em 2 fases, abordando as 3 fases iniciais do tratamento ortodôntico (alinhamento, nivelamento e fechamento de espaços) em uma única etapa e introduzindo, logo no início, um fio retangular superelástico, espera-se que haja uma redução no tempo de tratamento com a Terapia Bioeficiente ${ }^{135,136}$. Talvez a explicação para a diferença encontrada entre os resultados esperados e os do presente estudo, no qual os pacientes tratados com a técnica do Arco Reto e com a Terapia Bioeficiente levaram praticamente o mesmo tempo, seja porque os alunos da FOB, assim como o profissional da clínica particular, já acostumados a realizar tratamentos com a técnica do Arco Reto, trabalharam pela primeira vez com a Terapia Bioeficinte. Nesta primeira experiência, muitas dificuldades foram sendo encontradas no decorrer do tratamento e este pode ter sido o principal motivo da divergência do tempo de tratamento esperado e o encontrado no trabalho. Há sempre um período de adaptação a uma nova tecnologia, até que se consiga obter os melhores resultados que ela oferece. 
TABELA 6.2 - Tempos médios de tratamento, encontrados por alguns autores que estudaram reabsorção

\begin{tabular}{|c|c|}
\hline AUTORES & TEMPO MÉDIO (EM MESES) \\
\hline LEVANDER; MALMGREN76 & 19,5 \\
\hline LEVANDER; MALMGR,EN; ELIASSON77 & 20,5 \\
\hline DESHILDS 42 & 21,57 \\
\hline MIRABELLA; ARTUN88 & 24 \\
\hline PLETS et al. ${ }^{103}$ & 24,3 \\
\hline REMINGTON et a $1 .{ }^{111}$ & 26 \\
\hline SILVA FILHO et al. ${ }^{123}$ & 27 \\
\hline MCFADEN85 & 28,8 \\
\hline HARRIS; BACKER 52 & 29 \\
\hline HEMLEY 55 & 32 \\
\hline COPELAND; GREEN 38 & 34 \\
\hline KALLEY; PHILLIPS65 & 34 \\
\hline LINGE; LINGE79 & 42 \\
\hline SHARPE et al. 122 & 43,3 \\
\hline
\end{tabular}

\section{- Avaliação complementar: quantidade de extrações}

Diante das dificuldades normalmente encontradas na compatibilização dos grupos, em relação ao tipo de má oclusão ao início do tratamento, tipo de tratamento e extrações a serem realizadas, optou-se por comparar a quantidade de extrações realizadas em cada grupo, pois tal fato também poderia ter influenciado nos resultados ${ }^{19,77,85,137}$. A Tabela 5.10 e a Figura 5.8 mostram que o grupo 3 sofreu o maior número de extrações, em média $(2,43)$, enquanto que os grupos 1 e 2 apresentaram uma média de 1,79 e 2,06 extrações, respectivamente, diferença essa que não foi estatisticamente significante. Isto demonstra que os grupos são compativeis e podem ser comparados, apesar de não ter havido 
possibilidade de selecionar casos semelhantes inicialmente. Se os grupos são compatíveis quanto à quantidade de movimentação realizada, pode-se considerar que os resultados obtidos são consistentes. Mais importante, ainda, é o fato de que mesmo tendo apresentado uma quantidade ligeiramente maior de movimentação (não significante), a reabsorção foi ainda menor. Alguns autores sugerem que casos com extração apresentam maiores reabsorções, apesar de diversos trabalhos não terem conseguido comprovar essa associação ${ }^{19,77,85,137}$.

\subsubsection{Quantidade de reabsorção radicular decorrente do tratamento ortodôntico}

Em relação à amostra total $(n=712)$, apenas $2,25 \%$ dos dentes analisados não apresentaram comprometimento radicular (grau 0), 42,56\% apresentaram apenas arredondamento apical (grau 1) e 53,37\% mostraram reabsorção moderada (grau 2) (Figura 5.9). Ficou claro também que a reabsorção decorrente do tratamento raramente é acentuada (grau 3) ou extrema (grau 4), já que apenas 1,82\% dos dentes apresentaram essa relação. Os resultados assemelham-se aos de BECKS; HARRIS ${ }^{20}$, os quais observaram reabsorção em $62 \%$ dos incisivos analisados e consideraram “dentes reabsorvidos" somente aqueles com graus 2, 3 ou 4, o que, neste trabalho, totalizaria 55,90\%. Talvez essa diferença de quase 6\% esteja

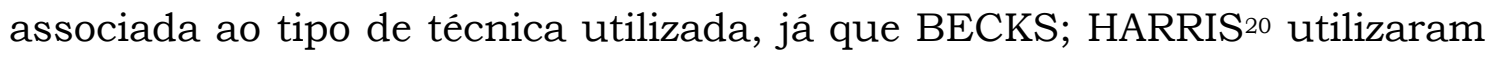
as técnicas do Arco de Canto e de Begg. Os resultados são parecidos também com os resultados de REMINGTON ${ }^{111}$, CANSANÇÃO ${ }^{35}$, KALEY; PHILLIPS65 e DESHILDS 42 e apresentam poucas diferenças dos resultados de LEVANDER; MALMGREN76, que encontraram reabsorção acentuada em $17 \%$ dos dentes. Entretanto, esses números podem ter sido agravados 
pelo fato da amostra ser composta apenas de incisivos superiores, que são os dentes mais reabsorvidos durante o tratamento ${ }^{1,2,15,35,38,52,55,65,67,92,101}$.

Entretanto, os achados deste trabalho diferem dos resultados de HEMLEY55, que encontrou reabsorção em apenas $20 \%$ dos dentes analisados. Vale ressaltar que a avaliação de HEMLEY55 foi somente após 1 ano de tratamento e não ao final do mesmo. Diferem também dos resultados de PLETS et al. ${ }^{103}$, que encontraram bem menos reabsorção, porém, como quantificaram a reabsorção em radiografias cefalométricas, isto pode ter minimizado a quantidade de reabsorção observada.

Todavia, a maioria dos autores $35,42,65,76,102,111,123$ concorda com este trabalho na constatação de que raramente a reabsorção radicular apical decorrente do tratamento ortodôntico é extrema, conforme mostra a Tabela 6.3.

Em relação ao número de pacientes, observou-se que apesar de 91,11\% deles terem apresentado reabsorção, variando de leve à moderada, apenas $8,88 \%$ dos pacientes apresentaram reabsorção preocupante clinicamente $^{79}$ (acentuada ou extrema) (Tabela 5.11/Figura 5.10). Estes resultados são semelhantes aos obtidos por ROSEMBERG ${ }^{113}$, TAITHONGCHAI; SOOKKORN; KILLIANY ${ }^{130}$. Concordam também com os de SILVA FILHO et al. ${ }^{123}$ e AHLGREN ${ }^{1}$ que encontraram reabsorção em $100 \%$ dos pacientes analisados e com os de DESHILDS ${ }^{42}$ que encontrou reabsorção em 99,08\% dos pacientes.

Por outro lado, os resultados obtidos diferem dos de KALEY; PHILLIPS65, que encontraram reabsorção extrema em somente 1\% dos pacientes, embora esses resultados possam ter sido influenciados pela presença de pré-molares na amostra. São diferentes também dos resultados de LINGE; LINGE79, os quais encontraram um encurtamento de mais de 2,5 milimetros em 16,5\% dos pacientes (vale ressaltar que os 
autores utilizaram apenas incisivos superiores, o que pode ter elevado a porcentagem de reabsorção) e, além disso, utilizaram apenas a técnica do Arco de Canto, que, juntamente com a técnica do Arco Reto, foi a responsável pela maior reabsorção encontrada neste trabalho.

TABELA 6.3 - Porcentagem de reabsorção extrema encontrada por alguns autores, em relação ao número de dentes

\begin{tabular}{|c|c|}
\hline AUTOR & REABSORÇÃO EXTREMA (\%) \\
\hline REMINGTON 111 & 1 \\
\hline LEVANDER; MALMGREN76 & 1 \\
\hline CANSANÇÃO 35 & 2,10 \\
\hline KALEY; PHILLIPS65 & 3 \\
\hline PHILLIPS 102 & 0,3 \\
\hline RONNERMAN; LARSSON 112 & 0 \\
\hline DESHILDS 42 & 0 \\
\hline
\end{tabular}

Embora a reabsorção radicular apical seja freqüente após o tratamento ortodôntico, raramente ela apresenta características clínicas significantes. Comumente, os dentes mantêm a vitalidade pulpar45,67,126, não apresentam escurecimento ${ }^{45,67,126}$, nem mobilidade aumentada45,67,126,131. KALKWARF; KREJCI; PAO66, em 1986, verificaram que, nos estágios iniciais da reabsorção, 3 milímetros de reabsorção radicular eqüivalem a 1 milimetro de perda de crista óssea. Quando a perda de comprimento ultrapassa 2 milimetros, esses 2 milímetros de reabsorção passam a eqüivaler a 1 milímetro de crista óssea. Tais resultados caracterizam a fraca significância clínica da reabsorção radicular apical em seus estágios mais precoces. Adicionado a isso, vários autores comprovaram que, na maioria das vezes, a reabsorção é suave e 
cessa no momento em que a força é removida15,19,20,115, não inviabilizando o tratamento,15,19,20. Desta forma, pode-se considerar que as melhoras decorrentes do tratamento justificam os riscos 53,123 .

\subsubsection{Prevalência de reabsorção nos incisivos}

Procurando apreciar a prevalência da reabsorção em cada incisivo, na amostra como um todo, encontrou-se resultados semelhantes aos da literatura ${ }^{1,2,15,20,55,65,92,122}$, ou seja, maior reabsorção nos incisivos centrais superiores, seguidos dos laterais superiores, dos centrais inferiores e por último, dos laterais inferiores, que foram os menos reabsorvidos (Figura 5.10). A maior reabsorção encontrada nos incisivos superiores pode estar relacionada à maior quantidade de movimento dentário, principalmente de intrusão, realizado para a correção ortodôntica ${ }^{41}$. Esses resultados, similares aos da literatura, ajudam a confirmar a precisão da metodologia empregada neste trabalho.

\subsubsection{Implicações clínicas}

O constante desenvolvimento e evolução dos materiais ortodônticos vêm proporcionando maior conforto para $\mathrm{O}$ profissional, caracterizado pela diminuição do tempo de cadeira e das consultas necessárias para ajuste do aparelho e, conseqüentemente, aumentando a produtividade, ou seja, promovendo um aumento do número de atendimentos. Os pacientes também têm sido favorecidos, já que esses novos materiais são menos traumáticos, melhoram rapidamente a estética, em conseqüência da realização precoce do nivelamento e alinhamento e reduzem a necessidade de ancoragem, devido ao menor atrito necessário para a movimentação. Essas características certamente prometem um grande futuro para a especialidade. 
Felizmente, parece que os ortodontistas, na busca de técnicas que minimizem a reabsorção radicular apical, decorrente do tratamento, encontraram a direção correta. Os bráquetes da Terapia Bioeficiente, associados a fios e molas superelásticas, foram eficazes na diminuição desse efeito deletério, decorrente do tratamento.

\subsubsection{Estudos futuros}

Está claro, entretanto, que esta pesquisa constitui apenas o início de um longo caminho. Diversos outros trabalhos necessitam ser realizados para melhor desvendarem as vantagens dessa nova tecnologia. Há que se estudar, ainda, as características da reabsorção óssea, realizando estudos microscópicos das alterações teciduais, decorrentes da movimentação induzida com esses aparelhos, o comportamento dos tecidos dentários e periodontais e, ainda, o tempo de tratamento, em uma amostra tratada por profissionais experientes nessa técnica. 


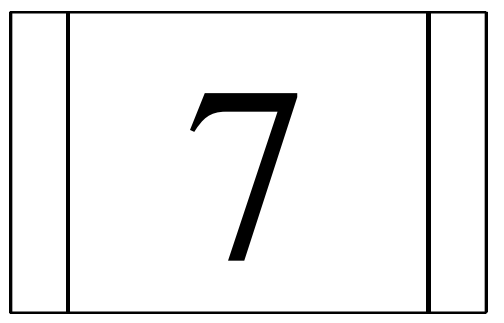

CONCLUSÕES 


\section{CONCLUSÕES}

Com base nos resultados obtidos e na metodologia utilizada, em relação à quantidade de reabsorção radicular decorrente do tratamento ortodôntico em pacientes tratados com a técnica do Arco de Canto Simplificada, do Arco Reto e com a Terapia Bioeficiente, pode se concluir que:

1. Em relação à comparação entre as 3 técnicas estudadas:

- O grupo 3 (Terapia Bioeficiente) apresentou menor de reabsorção, estatisticamente significante, que o grupo 1 (Arco do Canto Simplificada) e o grupo 2 (Arco Reto).

- Os pacientes tratados com a Terapia Bioeficiente e com o Arco Reto apresentaram um tempo de tratamento equivalente estatisticamente $\mathrm{e}$ menor em relação aos pacientes tratados com Arco de Canto Simplificada.

2. Do total de dentes examinados, $2,25 \%$ não apresentaram comprometimento radicular; $42,56 \%$ apresentaram apenas reabsorção leve; $53,37 \%$ apresentaram reabsorção moderada; $1,40 \%$, reabsorção acentuada e somente $0,42 \%$, reabsorção extrema.

3. Os dentes mais reabsorvidos, em decorrência do tratamento ortodôntico, foram, em ordem decrescente, os incisivos centrais superiores, os laterais superiores, os incisivos centrais inferiores e, por último, os laterais inferiores. 
ANEXOS 
ANEXO 1 Distribuição dos indivíduos estudados, segundo o sexo, a idade ao início do tratamento, os dentes extraídos e a duração do tratamento, nos grupos estudados

TABELA 1 Grupo 1 (técnica do Arco de Canto)

\begin{tabular}{|c|c|c|c|c|c|}
\hline N. ${ }^{o}$ & NOME & SEXO & $\begin{array}{c}\text { DURAÇÃO } \\
\text { (MESES) }\end{array}$ & $\begin{array}{c}\text { EXTRAÇÃO } \\
\text { (DENTES) }\end{array}$ & $\begin{array}{l}\text { IDADE } \\
\text { (MESES) }\end{array}$ \\
\hline $\mathrm{C} 1$ & A.F.F. & $M$ & 29 & $14,24,34,44$ & 155 \\
\hline $\mathrm{C} 2$ & C.L.F. & $\mathrm{F}$ & 15 & SEM & 149 \\
\hline $\mathrm{C} 3$ & C.A.D. & $M$ & 38 & $14,24,34,44$ & 140 \\
\hline $\mathrm{C} 4$ & C.H.P.M. & $M$ & 17 & $14,24,34,44$ & 164 \\
\hline $\mathrm{C} 5$ & C.C.Q. & $M$ & 15 & SEM & 176 \\
\hline $\mathrm{C} 6$ & C.A.P.T. & $M$ & 23 & $14,24,44$ & 168 \\
\hline $\mathrm{C} 7$ & D.S.D. & $M$ & 18 & SEM & 181 \\
\hline $\mathrm{C} 8$ & D.B.M. & $M$ & 40 & $14,24,34,44$ & 145 \\
\hline $\mathrm{C} 9$ & E.R.C.M. & $\mathrm{F}$ & 36 & $14,24,35,45$ & 192 \\
\hline $\mathrm{C} 10$ & E.N.A. & $\mathrm{F}$ & 50 & $24,34,44$ & 322 \\
\hline C11 & E.T.S. & $M$ & 41 & $14,24,34,44$ & 153 \\
\hline $\mathrm{C} 12$ & F.H.I. & $M$ & 17 & $14,24,34,44$ & 157 \\
\hline C13 & F.P. & $\mathrm{F}$ & 28 & SEM & 167 \\
\hline $\mathrm{C} 14$ & J.R.F. & $\mathrm{F}$ & 16 & SEM & 141 \\
\hline $\mathrm{C} 15$ & J.D.L. & M & 15 & SEM & 139 \\
\hline $\mathrm{C} 16$ & L.F. & $\mathrm{F}$ & 24 & SEM & 137 \\
\hline $\mathrm{C} 17$ & M.F.C. & $M$ & 56 & 14,24 & 121 \\
\hline $\mathrm{C} 18$ & M.M.L. & $M$ & 31 & SEM & 167 \\
\hline C19 & M.A.D. & $M$ & 37 & $14,24,34,44$ & 281 \\
\hline $\mathrm{C} 20$ & P.P.S. & $\mathrm{F}$ & 23 & SEM & 157 \\
\hline $\mathrm{C} 21$ & P.N. & $\mathrm{F}$ & 34 & SEM & 176 \\
\hline $\mathrm{C} 22$ & R.C.L. & $\mathrm{F}$ & 24 & SEM & 155 \\
\hline $\mathrm{C} 23$ & R.P.S. & $M$ & 11 & SEM & 159 \\
\hline $\mathrm{C} 24$ & R.S.D. & $M$ & 41 & $14,24,34,45$ & 163 \\
\hline $\mathrm{C} 25$ & S.W.C.I. & $M$ & 41 & $24,34,44$ & 184 \\
\hline $\mathrm{C} 26$ & S.G. & $\mathrm{F}$ & 36 & $14,24,35,45$ & 141 \\
\hline $\mathrm{C} 27$ & T.O.F. & $M$ & 27 & SEM & 171 \\
\hline $\mathrm{C} 28$ & T.Y. & $M$ & 29 & SEM & 134 \\
\hline $\mathrm{C} 29$ & V.R. & $\mathrm{F}$ & 46 & $14,24,34,44$ & 158 \\
\hline $\mathrm{C} 30$ & W.L. & $M$ & 16 & SEM & 161 \\
\hline
\end{tabular}




\section{Cont. ANEXO 1}

TABELA 2 Grupo 2 (técnica do Arco Reto)

\begin{tabular}{|c|c|c|c|c|c|}
\hline $\mathrm{N} .^{o}$ & NOME & SEXO & $\begin{array}{c}\text { DURAÇÃO } \\
\text { (MESES) }\end{array}$ & $\begin{array}{c}\text { EXTRAÇÃO } \\
\text { (DENTES) }\end{array}$ & $\begin{array}{l}\text { IDADE } \\
\text { (MESES) }\end{array}$ \\
\hline $\mathrm{R} 1$ & A.G. & $\mathrm{F}$ & 10 & $14,24,34,44$ & 178 \\
\hline $\mathrm{R} 2$ & A.L.G. & $\mathrm{F}$ & 12 & SEM & 148 \\
\hline R3 & A.C.D. & $M$ & 15 & $14,24,34,44$ & 164 \\
\hline $\mathrm{R} 4$ & A.M.S. & $M$ & 11 & $14,24,34,44$ & 187 \\
\hline R5 & B.M.F.B. & M & 19 & SEM & 152 \\
\hline $\mathrm{R} 6$ & C.C.O. & M & 33 & $14,24,34,44$ & 174 \\
\hline $\mathrm{R} 7$ & D.T.C. & $\mathrm{F}$ & 18 & SEM & 131 \\
\hline $\mathrm{R} 8$ & D.M.C. & $\mathrm{F}$ & 20 & $14,24,34,44$ & 223 \\
\hline $\mathrm{R} 9$ & G.E.Y. & $\mathrm{F}$ & 16 & SEM & 245 \\
\hline $\mathrm{R} 10$ & I.A. & $M$ & 21 & SEM & 168 \\
\hline $\mathrm{R} 11$ & I.L.C. & $M$ & 15 & SEM & 172 \\
\hline R12 & J.A. & $M$ & 10 & SEM & 145 \\
\hline R13 & K.A.B.M. & $\mathrm{F}$ & 19 & $14,24,34,44$ & 189 \\
\hline R14 & K.S.S. & $\mathrm{F}$ & 22 & 14,24 & 164 \\
\hline R15 & K.S. & $\mathrm{F}$ & 14 & SEM & 145 \\
\hline R16 & L.S.L. & $\mathrm{F}$ & 17 & 14,24 & 312 \\
\hline R17 & L.A.A.F. & M & 23 & $14,24,34,44$ & 140 \\
\hline R18 & L.P.C. & M & 17 & SEM & 143 \\
\hline R19 & M.A.C. & M & 22 & 14,24 & 164 \\
\hline $\mathrm{R} 20$ & M.C.H. & $\mathrm{F}$ & 12 & SEM & 151 \\
\hline $\mathrm{R} 21$ & M.G.A. & $\mathrm{F}$ & 19 & 14,24 & 159 \\
\hline $\mathrm{R} 22$ & P.E.D.C. & M & 24 & $14,24,34,44$ & 170 \\
\hline $\mathrm{R} 23$ & P.B. & $\mathrm{F}$ & 35 & $15,24,34,44$ & 174 \\
\hline $\mathrm{R} 24$ & R.A.M.F. & $M$ & 17 & $14,24,34,44$ & 165 \\
\hline $\mathrm{R} 25$ & R.P.V. & M & 37 & $14,24,34,44$ & 169 \\
\hline $\mathrm{R} 26$ & R.G.P. & M & 14 & SEM & 141 \\
\hline $\mathrm{R} 27$ & R.N.S. & $\mathrm{F}$ & 28 & 14,24 & 142 \\
\hline $\mathrm{R} 28$ & S.B. & $\mathrm{F}$ & 16 & SEM & 158 \\
\hline $\mathrm{R} 29$ & V.F.P. & $\mathrm{F}$ & 18 & $14,24,34,44$ & 183 \\
\hline R30 & W.D.G. & $M$ & 14 & $14,24,34,44$ & 152 \\
\hline
\end{tabular}


Cont. ANEXO 1

TABELA 3 Grupo 3 (Terapia Bioeficiente)

\begin{tabular}{|c|c|c|c|c|c|}
\hline $\mathrm{N} .^{\circ}$ & NOME & SEXO & $\begin{array}{c}\text { DURAÇÃO } \\
\text { (MESES) }\end{array}$ & $\begin{array}{c}\text { EXTRAÇÃO } \\
\text { (DENTES) }\end{array}$ & $\begin{array}{l}\text { IDADE } \\
\text { (MESES) }\end{array}$ \\
\hline B1 & A.A.J. & $M$ & 15 & $14,24,34,44$ & 197 \\
\hline B2 & C.M.F. & M & 16 & 35,45 & 275 \\
\hline B3 & C.M.S. & $\mathrm{F}$ & 17 & $14,24,34,44$ & 152 \\
\hline B4 & E.P. & $\mathrm{F}$ & 25 & SEM & 152 \\
\hline B5 & E.F. & $\mathrm{F}$ & 28 & $14,24,34,44$ & 163 \\
\hline B6 & J.T. & $\mathrm{F}$ & 22 & $15,25,35,45$ & 150 \\
\hline B7 & K.P. & $\mathrm{F}$ & 15 & SEM & 203 \\
\hline B8 & L.L.F. & $\mathrm{F}$ & 11 & 14,24 & 148 \\
\hline B9 & M.R.M. & $M$ & 25 & $16,24,34,44$ & 171 \\
\hline B10 & M.F. & M & 19 & $14,24,34,44$ & 226 \\
\hline B11 & M.M. & $\mathrm{F}$ & 23 & 14,24 & 152 \\
\hline B12 & N.M. & $\mathrm{F}$ & 11 & $14,24,35,45$ & 134 \\
\hline B13 & N.T. & $\mathrm{F}$ & 19 & SEM & 151 \\
\hline B14 & R.L. & $M$ & 15 & 14,24 & 155 \\
\hline B15 & R.M.A. & M & 16 & SEM & 136 \\
\hline B16 & R.H.S. & M & 24 & $14,24,34,44$ & 157 \\
\hline B17 & S.M. & $\mathrm{F}$ & 24 & $14,24,34,44$ & 188 \\
\hline B18 & T.L.S. & $M$ & 24 & $14,24,34,44$ & 125 \\
\hline B19 & V.Z. & $M$ & 13 & $14,24,34,44$ & 149 \\
\hline B20* & A.M.B.N. & $M$ & 12 & SEM & 162 \\
\hline B21* & A.S. & $\mathrm{F}$ & 21 & 14,24 & 265 \\
\hline B22* & A.A. & $M$ & 27 & $14,24,34,44$ & 197 \\
\hline B23* & E.C.F. & $M$ & 17 & $14,24,34,44$ & 151 \\
\hline B2 $24^{*}$ & E.Z. & $M$ & 23 & 14,24 & 284 \\
\hline B25* & F.A.R. & $M$ & 17 & $14,24,34,44$ & 169 \\
\hline B26* & G.M.F.G.P. & $\mathrm{F}$ & 14 & SEM & 156 \\
\hline B2 $27^{*}$ & J.F.C.F. & $M$ & 16 & $14,24,34,44$ & 137 \\
\hline B28* & M.G.N. & $\mathrm{F}$ & 20 & SEM & 144 \\
\hline B29* & P.G.N. & $\mathrm{F}$ & 20 & SEM & 131 \\
\hline B30* & V.M. & $M$ & 29 & 34 & 165 \\
\hline
\end{tabular}


ANEXO 2 Escores de reabsorção encontrados nos 3 grupos estudados

TABELA 1 Grupo 1 (técnica do Arco de Canto)

\begin{tabular}{|c|c|c|c|c|c|c|c|c|c|c|c|c|c|c|c|c|}
\hline $\mathbf{N}^{\circ}$ & $12 a$ & $12 b$ & $11 a$ & $11 b$ & $21 a$ & $21 b$ & $22 a$ & $22 b$ & $42 a$ & $42 b$ & $41 \mathrm{a}$ & $41 b$ & $31 a$ & $31 b$ & $32 a$ & $32 b$ \\
\hline$\overline{\mathrm{C} 1}$ & 2 & 2 & 2 & 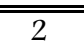 & 2 & 2 & 2 & 2 & 2 & 2 & 2 & 2 & 2 & 2 & 2 & 2 \\
\hline $\mathrm{C} 2$ & 2 & 2 & 1 & 1 & 2 & 1 & 2 & 1 & 1 & 1 & 2 & 2 & 2 & 2 & 1 & 1 \\
\hline C3 & 1 & 2 & 1 & 1 & 1 & 1 & 2 & 2 & 1 & 0 & 2 & 2 & 1 & 1 & 1 & 1 \\
\hline $\mathrm{C} 4$ & 1 & 1 & 2 & 2 & 2 & 2 & 2 & 2 & 1 & 1 & 2 & 2 & 2 & 1 & 1 & 1 \\
\hline C5 & 1 & 1 & 1 & 1 & 2 & 2 & 1 & 1 & 2 & 2 & 2 & 2 & 2 & 2 & 2 & 2 \\
\hline C6 & 1 & 1 & 1 & 1 & 1 & 1 & 2 & 2 & 2 & 2 & 2 & 2 & 1 & 1 & 2 & 2 \\
\hline $\mathrm{C7}$ & 2 & 2 & 1 & 1 & 2 & 2 & 2 & 2 & 1 & 1 & 1 & 1 & 1 & 1 & 1 & 1 \\
\hline $\mathrm{C} 8$ & 2 & 2 & 2 & 2 & 2 & 2 & 2 & 2 & 2 & 2 & 2 & 2 & 2 & 2 & 2 & 2 \\
\hline C9 & 2 & 2 & 2 & 2 & 2 & 2 & 2 & 2 & 1 & 1 & 2 & 2 & 2 & 2 & 2 & 2 \\
\hline C10 & 2 & 2 & 2 & 2 & 2 & 2 & 2 & 2 & 1 & 2 & 2 & 2 & 2 & 2 & 2 & 2 \\
\hline C11 & 2 & 3 & 2 & 2 & 2 & 2 & 3 & 3 & 2 & 2 & 2 & 2 & 2 & 2 & 1 & 1 \\
\hline C12 & 1 & 2 & 2 & 2 & 2 & 2 & 2 & 2 & 2 & 2 & 2 & 2 & 2 & 2 & 2 & 2 \\
\hline C13 & 2 & 2 & 2 & 2 & 1 & 1 & 2 & 2 & 2 & 2 & 2 & 2 & 2 & 1 & 1 & 1 \\
\hline $\mathrm{C} 14$ & 3 & 3 & 3 & 3 & 4 & 4 & 2 & 2 & 1 & 1 & 2 & 2 & 2 & 2 & 1 & 1 \\
\hline C15 & 2 & 1 & 2 & 2 & 1 & 2 & 2 & 2 & 0 & 0 & 1 & 1 & 1 & 1 & 0 & 0 \\
\hline C16 & 2 & 2 & 2 & 2 & 2 & 2 & 1 & 1 & 1 & 2 & 2 & 2 & 1 & 1 & 2 & 2 \\
\hline C17 & 1 & 1 & 2 & 2 & 2 & 2 & 1 & 1 & 2 & 2 & 2 & 2 & 2 & 2 & 2 & 2 \\
\hline C18 & 2 & 2 & 2 & 2 & 1 & 1 & 1 & 1 & 1 & 1 & 2 & 2 & 2 & 2 & 1 & 1 \\
\hline C19 & 2 & 1 & 1 & 1 & 1 & 1 & 1 & 1 & 2 & 2 & 2 & 2 & 2 & 1 & 1 & 1 \\
\hline $\mathrm{C} 2 \mathrm{O}$ & 1 & 1 & 1 & 2 & 1 & 2 & 2 & 1 & 1 & 1 & 1 & 1 & 2 & 2 & 1 & 1 \\
\hline $\mathrm{C} 21$ & 1 & 1 & 1 & 1 & 2 & 2 & 2 & 2 & 2 & 2 & 2 & 2 & 1 & 1 & 1 & 1 \\
\hline $\mathrm{C} 22$ & 2 & 2 & 1 & 2 & 2 & 2 & 2 & 2 & 1 & 1 & 2 & 2 & 2 & 2 & 1 & 1 \\
\hline C23 & 1 & 1 & 2 & 1 & 1 & 1 & 2 & 2 & 1 & 1 & 2 & 2 & 1 & 1 & 1 & 1 \\
\hline$\overline{C 24}$ & 1 & 1 & 2 & 2 & 2 & 2 & 2 & 2 & 1 & 1 & 1 & 1 & 1 & 1 & 2 & 2 \\
\hline$\overline{C 25}$ & $\overline{\mathrm{A}}$ & $\overline{\mathrm{A}}$ & 1 & 1 & 1 & 2 & 1 & 1 & 1 & 1 & 1 & 1 & 1 & 1 & 2 & 2 \\
\hline$\overline{\mathrm{C} 26}$ & 3 & 2 & 4 & 4 & 2 & 2 & 2 & 2 & 2 & 2 & 2 & 2 & 2 & 2 & 1 & 1 \\
\hline $\mathrm{C} 27$ & 1 & 1 & 1 & 1 & 2 & 2 & 1 & 1 & 1 & 1 & 2 & 2 & 2 & 2 & 1 & 1 \\
\hline C28 & 1 & 1 & 1 & 1 & 2 & 2 & 2 & 2 & 2 & 2 & 1 & 1 & 2 & 2 & 2 & 2 \\
\hline $\mathrm{C} 29$ & 2 & 2 & 2 & 2 & 2 & 2 & 2 & 2 & 2 & 1 & 2 & 2 & 2 & 2 & 2 & 1 \\
\hline $\mathrm{C} 30$ & 2 & 2 & 2 & 2 & 2 & 2 & 2 & 2 & 1 & 1 & 2 & 2 & 2 & 2 & 2 & 1 \\
\hline
\end{tabular}

$\left(a=1^{\circ}\right.$ examinador; $b=2^{\circ}$ examinador; $12=$ incisivo lateral superior direito, $11=$ incisivo central superior esquerdo, 21=incisivo lateral superior esquerdo, 42=incisivo lateral inferior direito, 41=incisivo central inferior direito, 31=incisivo central inferior esquerdo, 32=incisivo lateral inferior esquerdo, $A=d e n t e$ ausente) 


\section{Cont. ANEXO 2}

TABELA 2 Grupo 2 ( técnica do Arco Reto)

\begin{tabular}{|c|c|c|c|c|c|c|c|c|c|c|c|c|c|c|c|c|}
\hline $\mathrm{N}^{\mathrm{o}}$ & $12 \mathrm{a}$ & $12 b$ & $11 a$ & $11 b$ & $21 a$ & $21 b$ & $22 a$ & $22 b$ & $42 a$ & $42 b$ & $41 \mathrm{a}$ & $41 b$ & $31 a$ & $31 b$ & $32 a$ & $32 b$ \\
\hline 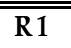 & $\bar{~} 1$ & 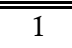 & 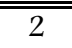 & $\overline{2}$ & 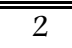 & 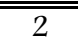 & $\overline{\overline{2}}$ & 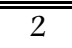 & 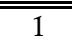 & 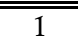 & 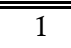 & 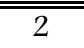 & $\overline{2}$ & $\bar{~} 2$ & $\overline{2}$ & $\overline{2}$ \\
\hline R2 & 2 & 2 & 1 & 1 & 1 & 1 & 1 & 1 & 1 & 1 & 1 & 1 & 1 & 1 & 1 & 1 \\
\hline R3 & 1 & 2 & 2 & 2 & 2 & 2 & 2 & 2 & 2 & 2 & 2 & 2 & 2 & 2 & 2 & 2 \\
\hline R4 & 2 & 1 & 2 & 2 & 1 & 1 & 2 & 2 & 2 & 2 & 2 & 2 & 2 & 1 & 1 & 1 \\
\hline R5 & 2 & 2 & 2 & 2 & 1 & 1 & 1 & 1 & 1 & 1 & 2 & 2 & 2 & 2 & 1 & 1 \\
\hline R6 & 2 & 2 & 2 & 2 & 2 & 2 & 2 & 2 & 2 & 1 & 1 & 1 & 1 & 1 & 1 & 1 \\
\hline R7 & 2 & 2 & 2 & 2 & 2 & 2 & 2 & 2 & 2 & 2 & 2 & 1 & 2 & 1 & 2 & 2 \\
\hline R8 & 2 & 2 & 2 & 2 & 2 & 2 & 2 & 2 & 2 & 2 & 2 & 1 & 2 & 2 & 2 & 2 \\
\hline R9 & 2 & 2 & 2 & 2 & 2 & 2 & 2 & 2 & $\mathrm{~A}$ & $\mathrm{~A}$ & 2 & 2 & 2 & 2 & 2 & 2 \\
\hline R10 & 2 & 2 & 2 & 2 & 2 & 2 & 2 & 2 & 1 & 1 & 2 & 2 & 1 & 1 & 1 & 1 \\
\hline $\bar{R} 11$ & 1 & 1 & 1 & 1 & 1 & 1 & 1 & 1 & 1 & 1 & 2 & 2 & 2 & 2 & 1 & 1 \\
\hline $\bar{R} 12$ & 2 & 1 & 1 & 1 & 1 & 1 & 2 & 2 & 1 & 1 & 2 & 2 & 2 & 1 & 2 & 2 \\
\hline $\bar{R} 13$ & 1 & 1 & 2 & 2 & 2 & 2 & 1 & 1 & 1 & 1 & 2 & 2 & 2 & 2 & 1 & 2 \\
\hline $\bar{R} 14$ & 2 & 2 & 2 & 2 & 1 & 1 & 2 & 1 & 2 & 2 & 1 & 1 & 2 & 1 & 1 & 1 \\
\hline $\bar{R} 15$ & 2 & 2 & 2 & 2 & 1 & 1 & 2 & 2 & 1 & 1 & 2 & 2 & 2 & 2 & 1 & 1 \\
\hline$R 16$ & 2 & 2 & 3 & 3 & 2 & 2 & 2 & 2 & 1 & 1 & 2 & 2 & 2 & 2 & 1 & 2 \\
\hline $\bar{R} 17$ & 1 & 1 & 2 & 2 & 2 & 2 & 1 & 1 & 1 & 1 & 2 & 2 & 2 & 2 & 1 & 1 \\
\hline $\bar{R} 18$ & 2 & 2 & 2 & 2 & 2 & 2 & 2 & 2 & 1 & 1 & 2 & 2 & 2 & 2 & 2 & 2 \\
\hline$\overline{R 19}$ & 2 & 2 & 4 & 4 & 3 & 3 & 2 & 2 & 2 & 2 & 2 & 2 & 2 & 2 & 2 & 2 \\
\hline R20 & 2 & 2 & 1 & 2 & 2 & 2 & 1 & 1 & 1 & 1 & 2 & 2 & 1 & 1 & 1 & 1 \\
\hline $\bar{R} 21$ & 2 & 2 & 2 & 2 & 2 & 2 & 1 & 1 & 2 & 2 & 2 & 2 & 2 & 2 & 2 & 1 \\
\hline R22 & 2 & 2 & 2 & 2 & 2 & 2 & 2 & 2 & 1 & 2 & 2 & 2 & 2 & 2 & 1 & 1 \\
\hline R23 & 2 & 1 & 2 & 2 & 2 & 2 & 2 & 2 & 1 & 1 & 2 & 2 & 2 & 2 & 1 & 1 \\
\hline $\bar{R} 24$ & 1 & 1 & 1 & 1 & 2 & 2 & 1 & 1 & 1 & 1 & 1 & 1 & 1 & 1 & 2 & 1 \\
\hline R25 & 2 & 2 & 2 & 2 & 1 & 1 & 1 & 1 & 1 & 1 & 2 & 2 & 1 & 1 & 2 & 2 \\
\hline R26 & 1 & 1 & 1 & 1 & 2 & 2 & 1 & 1 & 1 & 1 & 1 & 1 & 1 & 1 & 1 & 1 \\
\hline R27 & 2 & 2 & 2 & 2 & 2 & 2 & 2 & 2 & 1 & 1 & 1 & 1 & 1 & 1 & 2 & 1 \\
\hline R28 & 2 & 2 & 2 & 2 & 1 & 1 & 2 & 1 & 2 & 2 & 2 & 2 & 2 & 2 & 1 & 1 \\
\hline R29 & 1 & 1 & 1 & 1 & 1 & 1 & 2 & 1 & 2 & 2 & 2 & 2 & 2 & 2 & 2 & 2 \\
\hline R30 & 1 & 1 & 2 & 2 & 2 & 2 & 2 & 2 & 1 & 1 & 2 & 1 & 2 & 2 & 2 & 2 \\
\hline
\end{tabular}

$\left(a=1^{\circ}\right.$ examinador; $b=2^{\circ}$ examinador; $12=$ incisivo lateral superior direito, $11=$ incisivo central superior esquerdo, 21=incisivo lateral superior esquerdo, 42=incisivo lateral inferior direito, 41=incisivo central inferior direito, 31=incisivo central inferior esquerdo, 32=incisivo lateral inferior esquerdo, $\mathrm{A}=$ dente ausente) 
Cont. ANEXO 2

TABELA 3 Grupo 3 (Terapia Boeficiente)

\begin{tabular}{|c|c|c|c|c|c|c|c|c|c|c|c|c|c|c|c|c|}
\hline $\mathbf{N}^{\mathrm{o}}$ & $12 a$ & $12 b$ & $11 \mathrm{a}$ & $11 b$ & $21 a$ & $21 b$ & $22 a$ & $22 b$ & $42 a$ & $42 b$ & $41 a$ & $41 b$ & $31 a$ & $31 b$ & $32 a$ & $32 b$ \\
\hline 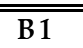 & 2 & 2 & 3 & 3 & 3 & 3 & 2 & 2 & $\bar{~} 1$ & 1 & 2 & 2 & $\bar{~} 1$ & 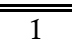 & $\bar{~} 1$ & 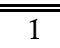 \\
\hline B2 & 2 & 1 & 3 & 3 & 2 & 2 & 1 & 1 & 2 & 2 & 1 & 1 & 1 & 1 & 1 & 1 \\
\hline B3 & 2 & 2 & 1 & 1 & 2 & 2 & 1 & 1 & 1 & 2 & 2 & 2 & 1 & 1 & 1 & 1 \\
\hline B4 & 2 & 2 & 2 & 2 & 1 & 1 & 2 & 2 & 2 & 2 & 1 & 1 & 1 & 1 & 1 & 1 \\
\hline B5 & 1 & 1 & 2 & 2 & 2 & 2 & 2 & 2 & 1 & 1 & 2 & 2 & 1 & 1 & 1 & 1 \\
\hline B6 & 1 & 1 & 1 & 1 & 1 & 1 & 1 & 1 & 1 & 1 & 1 & 1 & 1 & 1 & 1 & 1 \\
\hline B7 & 1 & 2 & 2 & 2 & 1 & 1 & 1 & 1 & 0 & 0 & 1 & 1 & 1 & 1 & 0 & 0 \\
\hline B8 & 2 & 2 & 2 & 2 & 1 & 1 & 2 & 2 & $\bar{A}$ & $\bar{A}$ & 1 & 1 & 1 & 1 & 1 & 1 \\
\hline B9 & 1 & 2 & 1 & 1 & 2 & 3 & 2 & 2 & 1 & 1 & 1 & 1 & 2 & 2 & 1 & 1 \\
\hline B10 & 2 & 2 & 3 & 3 & 2 & 2 & 2 & 2 & 1 & 0 & 1 & 0 & 2 & 1 & 1 & 0 \\
\hline$\overline{B 11}$ & 2 & 2 & 1 & 1 & 1 & 1 & 1 & 1 & 1 & 1 & 1 & 1 & 1 & 1 & 2 & 2 \\
\hline B12 & 2 & 2 & 2 & 2 & 1 & 2 & 2 & 2 & 2 & 2 & 2 & 2 & 2 & 2 & 1 & 1 \\
\hline B13 & 1 & 1 & 2 & 2 & 2 & 2 & 2 & 2 & 1 & 0 & 2 & 1 & 2 & 1 & 1 & 1 \\
\hline B14 & 2 & 2 & 2 & 2 & 2 & 2 & 2 & 2 & 1 & 1 & 2 & 2 & 1 & 1 & 1 & 1 \\
\hline B15 & 1 & 1 & 1 & 1 & 2 & 2 & 1 & 1 & 1 & 1 & 1 & 1 & 0 & 0 & 0 & 0 \\
\hline$\overline{B 16}$ & 2 & 2 & 2 & 2 & 1 & 1 & 2 & 2 & 1 & 0 & 2 & 2 & 1 & 1 & 1 & 0 \\
\hline$\overline{B 17}$ & 2 & 2 & 2 & 2 & 2 & 2 & 2 & 2 & 1 & 1 & 1 & 1 & 2 & 2 & 1 & 2 \\
\hline$\overline{B 18}$ & 1 & 1 & 2 & 2 & 2 & 2 & 1 & 1 & 1 & 1 & 2 & 2 & 1 & 1 & 1 & 1 \\
\hline$\overline{B 19}$ & 2 & 2 & 1 & 1 & 2 & 2 & 1 & 1 & 1 & 1 & 2 & 2 & 1 & 2 & 1 & 1 \\
\hline B20 & 1 & 1 & 1 & 1 & 1 & 1 & 0 & 0 & 1 & 1 & 1 & 1 & 1 & 1 & 1 & 1 \\
\hline B21 & 2 & 2 & 2 & 2 & 2 & 2 & 1 & 1 & 1 & 1 & 1 & 1 & 1 & 1 & 1 & 1 \\
\hline B22 & 1 & 1 & 2 & 2 & 2 & 2 & 1 & 1 & 1 & 1 & 2 & 2 & 0 & 1 & 1 & 1 \\
\hline$\overline{B 23}$ & 1 & 1 & 2 & 2 & 1 & 1 & 1 & 1 & 1 & 1 & 1 & 1 & 1 & 1 & 1 & 1 \\
\hline$\overline{B 24}$ & 2 & 2 & $E$ & $\bar{E}$ & $\bar{E}$ & $E$ & 2 & 2 & 1 & 1 & 1 & 1 & $E$ & $\bar{E}$ & 2 & 2 \\
\hline$\overline{B 25}$ & 2 & 2 & 1 & 1 & 2 & 2 & 2 & 2 & 0 & 0 & 1 & 1 & 1 & 1 & 1 & 1 \\
\hline B26 & 1 & 1 & 1 & 1 & 2 & 2 & 1 & 1 & 0 & 0 & 2 & 2 & 1 & 1 & 0 & 0 \\
\hline B27 & 1 & 1 & 2 & 2 & 2 & 2 & 2 & 2 & 1 & 1 & 1 & 1 & 1 & 1 & 0 & 0 \\
\hline$\overline{B 28}$ & 2 & 2 & 1 & 1 & 2 & 2 & 2 & 2 & 0 & 0 & 1 & 1 & 1 & 1 & 0 & 0 \\
\hline$\overline{B 29}$ & 0 & 0 & 1 & 1 & 2 & 2 & 1 & 1 & 1 & 1 & 1 & 1 & 1 & 1 & 0 & 0 \\
\hline B30 & $\mathrm{X}$ & $\mathrm{X}$ & 2 & 2 & 1 & 1 & $\mathrm{X}$ & $\mathrm{X}$ & 1 & 1 & 1 & 1 & 1 & 1 & 1 & 1 \\
\hline
\end{tabular}

$\left(a=1^{\circ}\right.$ examinador; $b=2^{\circ}$ examinador; $12=$ incisivo lateral superior direito, $11=$ incisivo central superior esquerdo, 21=incisivo lateral superior esquerdo, 42=incisivo lateral inferior direito, 41=incisivo central inferior direito, 31=incisivo central inferior esquerdo, 32=incisivo lateral inferior esquerdo, $\mathrm{A}=\mathrm{dente}$ ausente, $\mathrm{X}=$ dente impossível de ser visualizado na radiografia, $\mathrm{E}=$ dente com endodontia realizada durante $\mathrm{o}$ tratamento) 
REFERÊNCIAS BIBLIOGRÁFICAS 


\section{REFERÊNCIAS BIBLIOGRÁFICAS}

1. AHLGREN, J. A ten year evaluation of the quality of orthodontic treatment. Sweed Dent. J., v.17, n.5, p.201 9, 1993.

2. ALEXANDER, S. A. Levels of root resorption associated with continuous arch sectional arch mechanics. Amer. J. Orthodont. Dentofac. Orthop., v.110, n.3, p.321 4, Sept. 1996.

3. ALVARES, L. C.; TAVANO, O. A imagem radiográfica. In: Curso de radiologia em odontologia. 2. ed. São Paulo, Santos, 1990. Cap. 2, p.17 36.

4. ALVARES, L. C.; TAVANO, O. Técnicas radiográficas. In: Curso de radiologia em odontologia. 2. ed. São Paulo, Santos, 1990. Cap. 4, p.51 117.

5. ANDREASEN, G. F.; HILLEMAN, T. B. An evaluation os 55 cobalt substituted nitinol wire for use in orthodontics. J. Amer. dent. Ass., v.82, n.6, p.1373 5, June 1971.

6. ANDREASEN, G. F.; MONTAGANO, L.; KRELL, D. An investigation of linear dimensional changes as a function of temperature in an 0.010 inch 55 cobalt substituted annealed nitinol alloy wire. Amer. J. Orthodont., v.82, n.6, p.469 72, Dec. 1982.

7. ANDREASEN, J. O. External root resorption: its implication in dental traumatology, paedodontics, periodontics, orthodontics and endodontics. Int. Endod. J., v.18, p.109 $18,1985$.

8. ANDREASEN, J. O. Review of root resorption systemes models. Etiology and homeostatic mechanisms of the periodontal ligament. In: DAVIDOVICH, Z., ed. Biological mechanisms of tooth eruption and root resorption. Ohio, Columbus, 1988. p.9 21.

9. ANDREASEN, J. O. Summary of root resorption. In: DAVIDOVICH, Z., ed. Biological mechanisms of tooth eruption and root resorption. Ohio, Columbus, 1988. p.399 401.

10. ANDREWS, L. F. Six keys to normal occlusion. Amer. J. Orthodont., v.62, n.3, p.296 309, Sept. 1972.

11. ANDREWS, L. F. The straigh -wire appliance origen, controversy, comentary. J. clin. Orthodont., v.10, n.2, p.99 114, Feb. 1976.T

12. ANDREWS, L. F. The straight -wire appliance explained and compared. J. clin.

\footnotetext{
* Normas recomendadas para uso no âmbito da Universidade de São Paulo, com base no documento "Referências Bibliográficas: exemplos", emanado do Conselho Supervisor do Sistema Integrado de Bibliotecas da USP, em reunião de 20 de setembro de 1990.
} 
Orthodont., v.10, n.3, p.174 95, Mar. 1976.

13. ANGLE, E H. The latest and best in orthodontic mechanism. Dental Cosmos, v.70, n.12, p. 1143 56, Dec. 1928.

14. ARMitAGE, G. C. Cemento. In: BHASKAR, S. N. Histologia e embriologia oral de Orban. 8.ed. São Paulo, Artes Médicas, 1978. Cap.6, p.185 208.

15. ARNESEN, F. A. Avaliação da reabsorção radicular externa, consecutiva ao tratamento ortodônico. Piracicaba, 1984. 88p. Dissertação (Mestrado) Faculdade de Odontologia de Bauru, Universidade Estadual de Campinas.

16. ASBELL, M. A.; HILL, N. J. C. A brief history of orthodontics. Amer. J. Orthodont. Dentofac. Orthop., v.98, n.3, p.206 213, Sept. 1990.

17. AVELlanAL, C. D. Dicionário odontológico, 2 ed. Buenos Aires, Editora Mundi, 1964. $777 \mathrm{p}$.

18. BACCHI, E. O. S. A reabsorção radicular externa e alterações periodontais do rato frente a movimentação ortodôntica e diferentes teores protéicos na dieta. Piracicaba, 1994. 93p. Tese (Livre Docência). Universidade Estadual de Campinas.

19. BAUMRIND, S.; KORN, E. L.; BOYD, R. L. Apical root resorption in orthodontic treated adults. Amer. J. Orthodont. Dentofac. Orthop., v.110, n.3, p.311 20, Sept. 1996.

20. BECK, B.; HARRIS, E. F. Apical root resorption in orthodontically treated subjects. Analysis of edgewise and light wire mechanics. Amer. J. Orthodont. Dentofac. Orthop., v.105, n.4, p.350 61, Apr. 1994.

21. BECKS, H. Orthodontic prognosis: evaluation of routine dentomedical examination to determine "good and poor risks". Amer. J. Orthodont., v.25, p.610 24, 1939. apud BREZNIAK, N.; WASSERSTEIN, A. Root resorption after orthodontic treatment: part 1. Literature review. Amer. J. Orthodont. Dentofac. Orthop., v.103, n.1, p.62 6, Jan. 1993.

22. BECKS, H.; MARShall, J. A. Resorption or absorption. J. Amer. dent. Ass., v.19, n.9, p.1528 37, Sept. 1932.

23. BEGG, P. R. Light arch wire technique. Amer. J. Orthodont., v.47, n.1, p.30 48, Jan. 1961.

24. BLAKE, M.; WOODSIDE, D. G., PHAROAH, M. J. A radiographic comparation of apical root resorption after orthodontic treatment with the edgewise and Speed appliances. Amer. J. Orthodont. Dentofac. Orthop., v.108, n.1, p.76 84, July 1995. 
25. BRADEL, J.F. One hundred year of development in metallurgy and its relation to orthodontia. J. Amer. dent. Ass., v.21, n.6, p.1018 22, June 1934.

26. BREZNIAK, N.; WASSERSTEIN, A. Root resorption after orthodontic treatment: part 1. Literature review. Amer. J. Orthodont. Dentofac. Orthop., v.103, n.1, p.62 6, Jan. 1993.

27. BREZNIAK, N.; WASSERSTEIN, A. Root resorption after orthodontic treatment: part 2. Literature review. Amer. J. Orthodont. Dentofac. Orthop., v.103, n.2, p.138 46, Feb. 1993.

28. BRUDVIK, P.; RYGH, P. Root resorption after local injection of prostaglandin E2 during experimental tooth movement. Eur. J. Orthodont., v.13, n.4, p.255 63, Aug. 1991.

29. BRUDVIK, P.; RYGH, P. Non clast cells start orthodont root resorption in the periphery of hyalinized zones. Eur. J. Orthodont., v.15, n.6, p.467 80, Dec. 1993.

30. BRUDVIK, P.; RYGH, P. Multi nucleated cells remove the main hialinized tissue and start resorption of adjacent root surfaces. Eur. J. Orthodont., v.16, n.4, p.265 73, Aug. 1994.

31. BRUDVIK, P.; RYGH, P. Transition and determinants of orthodontic root resorption repair sequence. Eur. J. Orthodont., v.17, n.3, p.177 88, June 1995.

32. BRUDVIK, P.; RYGH, P. The repair of orthodontic root resorption: an ultrastructural study. Eur. J. Orthodont., v.17, n.3, p.189 98, June 1995.

33. BURSTONE, C. J.; GOLDBERG, A. J. Beta titanium: a new orthodontic alloy. Amer. J. Orthodont.,v.77, n.2, p.121 32, Feb. 1980.

34. BURSTONE, C. J.; QIN, B.; MORTON, J.Y. Chinese NiTi wire A new orthodontic alloy. Amer. J. Orthodont., v.87, n.6, p.445 52, June 1985.

35. CANSANÇÃO, J. M. Avaliação radiográfica da reabsorção radicular, consecutiva ao tratamento ortodôntico, pela técnica do arco do canto, relacionada com o sexo, a idade, a duração do tratamento, o período de uso do arco retangular e do aparelho extrabucal. Bauru, 1980, 68p. Dissertação (Mestrado) Faculdade de Odontologia de Bauru, Universidade de São Paulo

36. CHAMBERS, T. J. Resorption of bone. In: DAVIDOVICH, Z., ed. Biological mechanisms of tooth eruption and root resorption. Ohio, Columbus, 1988. p.93 100.

37. CONOVER, W. J. Pratical non parametric estatistic. New York, John Wiley and Suns, 1971. 
38. COPELAND, S.; GREEN, L. J. Root resorption in maxillary central incisors following active orthodontic treatment. Amer. J. Orthodont., v.89, n.1, p.51 5, Jan. 1986.

39. COTRAN, R., S.; KUMAR, V.; ROBBINS, S. L. Inflamation and repair. In: Pathologic basis of disease. 5. ed. Philadelphia, Saunders, 1994. Cap.3, p.51 92.

40. CUETO, H. Z. A little bit of history: The first direct bonding in orthodontia. Amer. J. Orthodont., v.98, n.3, p.276 7, Sept. 1990.

41. DERMAUT, L. R.; DE MUNCK, A. Apical root resorption of upper incisor caused by intrusive tooth movement: A radiographic study. Amer. J. Orthodont. Dentofac. Orthop., v.90, n.4, p.321 26, Oct. 1986.

42. DESHIELDS, R. W. A study of root resorption in treated Class II, Division I malocclusion. Angle Orthodont., v.39, n.4, p.2331 45, Oct. 1969.

43. EDITOR'S CORNER. In memorian. Charles Tweed, Harry Bull. J. clin. Orthodont., v.4, n.2, p.67 8, Feb. 1970.

44. ENGSTRÖM, C.; GRANSTRÖM, G.; THILANDER, B. Effect of orthodontic force on periodontal tissue metabolism: a histologic and biochemical study in normal and hipocalcemic young rats. Amer. J. Orthodont. Dentofac. Orthop., v.93, n.6, p.486 95, June 1988.

45. FEIGLIN, B. Root resorption. Aust. dent. J., v.31, n.1, p.12 22, Jan. 1986.

46. FOLLIN, M. E.; ERICSSON, I.; THILANDER, B. Occurrence and distribution of root resorption in orthodontically moved premolars in dogs. Angle Orthodont., v.56, n.2, p.164 75, Apr. 1986.

47. GOAZ, P. W.; WHITE, S. C. Intraoral radiographic examination. In: Oral Radiollogy. Principles and Interpretation. 3. ed. Saint Loius, Mosby, 1994. Cap.9, p.151 218.

48. GOLDIE, R. S.; KING, G. J. Root resorption and tooth movement in orthodontically treated, calcium deficient, and lactating rats. Amer. J. Orthodont., v.85, n.5, p.424 30, May 1984.

49. GOLDIN, B. Labial root torque: effect on the maxilla and incisor root apex. Amer. J. Orthodont. Dentofac. Orthop., v.95, n.3, p.208 19, Mar. 1989.

50. GOLDSON, L.; HENRIKSON, C. O. Root resorption during Begg treatment. A longitudinal roentgenologic study. Amer. J. Orthodont., v.68, n.1, p.55 66, July 1975.

51. HANSON, H. G. The SPEED system: a report on the devepment of a new edgewise appliance. Amer. J. Orthodont.,v.78, n.3, p.243 65, Sept. 1980. 
52. HARRIS, E. F.; BACKER, W.C. Loss of root length and crestal bone height before and during treatment in adolescent and adult orthodontic pacients. Amer. J. Orthodont. Dentofac. Orthop., v.98, n.5, p.463 9, Nov. 1990.

53. HARRIS, E. F.; BUTLER, M. L. Patterns of incisor root resorption before and after orthodontic correction in cases with anterior open bites. Amer. J. Orthod Dentofac. Orthop. v.101, n.2, p.112 9, Feb. 1992.

54. HARRIS, E. F.; KINERET, S. E.; TOLLEY, E. A. A heritable component for external apical root resorption in patients treated orthodontically. Amer. J. Orthodont. Dentofac. Orthop., v.111, n.3, p.301 9, Mar. 1997.

55. HEMLEY, S. The incidence of root resorption of vital permanent teeth. J. dent. Res., v.20, p.133 41, 1941.

56. HENDRIX, I. et al. A radiographic study of posterior apical root resorption in orthodontic patients. Amer. J. Orthodont. Dentofac. Orthop., v.105, n.4, p.345 9, Apr. 1994.

57. HERZBERG, B. L. Bone changes and orthodontic tooth movement. J. Amer. dent. Ass., v.19, n.10, p.1777 88, Oct. 1932.

58. HILL, F. J.; ORTH, D. Iatrogenic root resorption of upper first permanent molars associated with orthodontic treatment. Brit. J. Orthodont., v.14, n.2, p.109 13, Apr. 1987.

59. HOLDAWAY, R.A. Bracket angulation as applied to the edgewise appliance. Angle Orthodont., v.22, n.4, p.227 36, Oct. 1952.

60. JANSON, G. R. P. A evolução da mecânica ortodôntica. Rev. gaúcha odont., v.45, n.2, p.118, mar./abr. 1997.

61. JANSON, G. R. P. et al. Tratamento ortodôntico com o Sistema Viazis. Rev. dent. Press Ortodont. Ortop., v.2, n.1, p.13 32, jan./fev. 1997.

62. JARABAK, J. R.; FIZZELL, J. A. Design of appliance and application of helical loop forces. In: Technique and treatment with the light wire appliances. Saint Louis, C.V Mosby, 1963. Cap.7, p.283 339.

63. JONES, S. J.; BOYDE, A. The resorption of dentine and cementum in vivo and in vitro. In: DAVIDOVICH, Z., ed. Biological mechanisms of tooth eruption and root resorption. Ohio, Columbus, 1988., p.335 54. 
64. JULIANO, M. L.; GARDUCCI, M. G. Emprego dos fios superelásticos em ortodontia. Rev. Paul. Odontol., v.18, n.6, nov./dez. 1996.

65. KALEY, J.; PHILLIPS, C. Factors related to root resorption in edgewise practice. Angle Orthodont., v.61, n.2, p.125 32, Summer 1991.

66. KALKWARF, K. L.; KREJCI, R. F.; PAO, Y. C. Effect of apical root resorption on periodontal support. J. prosth. Dent., v.56, n.3, p.317 19, Sept. 1986.

67. KETCHAM, A. H. A preliminary report of investigation of apical root resorption of permanent teeth. Int. J. Orthodont., oral Surg. and Radiog., v.18, n.2, p.97 127, Feb. 1927.

68. KJAER, I. Morphological characteristics of dentitions developing excessive root resorption during orthodontic treatment. Eur. J. Orthodont., v.17, n.1, p.25 34, Feb. 1995.

69. KROGMAN, W. M. Craniometry and cephalometry as research tools in growth of head and face. Amer. J. Orthodont., v.37, p.406 14, 1951.

70. KUSY, R. P. A review of contemporary archwires: Their properties and characteristics. Angle Orthodont., v.67, n.3, p.197 208, June 1997.

71. KUSY, R. P.; DILLEY, G. J. Elastic property ratios of a triple -strand stainless steel arch wire. Amer. J. Orthodont. Dentofac. Orthop.,v.86, n.5, p.177 88, Sept. 1984.

72. LAFERLA, M. R. Ion implantation: effect on frictional resistance to movement. California, 1996. Dissertation (Master of Science) Faculty of the graduate school, University of Souther California.

73. LAGERSTRÖM, L.; KRISTERSON, L. Influence of orthodontic treatment on root development of premolars. Amer. J. Orthodont., v.89, n.2, p.146 50, Feb. 1986.

74. LANGLAIS, R. P.; LANGLAND, O. E. NORTJÉ, C. J. Decision making in dental radiology. In:_. Diagnostic imaging of the jaws. Baltimore, Williams \& Wilkins, 1995. Cap.1, p.1 17.

75. LEIKER, B. J. et al. The effects of exogenous prostaglandins on orthodontic tooth movement in rats. Amer. J. Orthodont. Dentofac. Orthop., v.108, n.4, p.380 8, Oct. 1995.

76. LEVANDER, E.; MALMGREN, O. Evaluation of the risk of root resorption during orthodont. treatment: A study ou upper incisors. Eur. J. Orthodont., v.10, n.1, p.30 8, Feb. 1988. 
77. LEVANDER, E.; MALMGREN, O.; ELIASSON, S. Evaluation of root resorption in relation to two orthodontic treatment regimes. A clinical experimental study. Eur. J. Orthodont., v.16, n.3, p.223 8, June 1994.

78. LINGE, B. O.; LINGE, L. Apical root resorption in upper anterior teeth. Eur. J. Orthodont., v.5, n.3, p.173 83, Aug. 1983.

79. LINGE, L.; LINGE, B.O. Patient characteristics and treatment variables associated with apical root resorption during orthodontic treatment. Amer. J. Orthodont. Dentofac. Orthop., v.99, n.1, p.35 43, Jan. 1991.

80. LUNDGREN, D; OWMAN MOLL, P.; KUROL, J. Early tooth movement pattern after application of controlled continuous orthodontic force. A human experimental model. Amer. J. Orthodont. Dentofac. Orthop., v.110, n.3, p.287 94, Sept. 1996.

81. MALMGREN, O. et al. Root resorption after orthodontic treatment of traumatized teeth. Amer. J. Orthodont., v.82, n.6, p.487 91, Dec. 1982.

82. MARSHALl, J. A. Physiologic and traumatic apical resorption. J. Amer. dent. Ass., v.22, n.9, p.1545 58, Sept. 1935.

83. MARTINS, D. R.; CANSANÇÃO, J. M.; SANCHEZ, J. F. Avaliação radiográfica da reabsorção radicular, consecutiva ao tratamento ortodôntico (cinco anos após a remoção dos aparelhos). Ortodontia, v.27, n.3, p.4 8, set./dez., 1994.

84. MASSLER, M.; MALONE, A. J. Root resorption in human permanent teeth. Amer. J. Orthodont., v.40, n.8, p.619 33, Aug. 1954.

85. MCFADEN, M. W. et al. A study of the relationship between incisor intrusion and root shortening. Amer. J. Orthodont. Dentofac. Orthop., v.96, n.5, p.390 6, Nov. 1989.

86. MCNICOL, A.; STIRRUPS, D. R. Radiation dose during the dental radiographic tecniques most frequently used during orthodontic treatment. Eur. J. Orthodont., v.7, n.3, p.163 71, 1985.

87. MEGHJI, S. Bone remodelling. Brit. dent. J., v.172, n.6, p.235 42, Mar. 1992.

88. MIRABELLA, D; ARTUN, J. Risk factors for apical root resorption of maxillary anterior teeth in adult orthodontic patients. Amer. J. Orthodont. Dentofac. Orthop., v.108, n.1, p.48 55, 1995.

89. MIURA, F. Reflections on my involvement in orthodontic research. Amer. J. Orthodont., v.104, n.6, p.531 38, Dec. 1993.

90. MIURA, F. et al. The super elastic property of the Japanese NiTi alloy wire for use in orthodontic. Amer. J. Orthodont. Dentofac. Orthop., v.90, n.1, p.1 10, July 
1986.

91. MYRICK JUNIOR, A. C. Is tissue resorption and replacemnet in permanent teeth of mammals caused by stress induced hypocalcemis? In: DAVIDOVICH, Z., ed. Biological mechanisms of tooth eruption and root resorption. Ohio, Columbus, 1988. p.379 89.

92. NEWMAN, W. G. Possible etiologic factors in external root resorption. Amer. J. Orthodont., v.67, n.5, p.522 39, May 1975.

93. ODENRICK, L.; BRATTSTRÖM, V. The effect of nailbiting on root resorption during orthodontic treatment. Europ. J. Orthodont., v.5, n.3, p.185 88, Aug. 1983.

94. OPPENHEIM, A. Tissue changes, particulary of the bone, incident to tooth movement. The Amer. Orthodont., v.3, n.2, p.58 67, 1911.

95. OTOLLENGUI, R. The phisiological and pathological resorption of tooth roots. Items of Interest., v.36, p.332 355, 1914.

96. OWMAN MOLL, P.; KUROL, J.; LUNDGREN, D. Continuous versus interrupted continuous orthodontic force related to early tooth movement and root resorption. Angle Orthodont., v.65, n.6, p.395 402, 1995.

97. OWMAN MOLL, P.; KUROL, J.; LUNDGREN, D. Repair of orthodontically induced root resorption in adolescents. Angle Orthodont., v.65, n.6, p.403 10, 1995.

98. OWMAN MOLL, P.; KUROL, J.; LUNDGREN, D. Time related root resoption after application of a controlled continuous orthodontic force. Amer. J. Orthodont. Dentofac. Orthop., v.110, n.3, p.303 10, Sept. 1996.

99. PEREIRA, A. Dicionário de sinônimos odontológicos. Rio de Janeiro, Científica, 1956. $322 \mathrm{p}$.

100. PEREIRA, A. A. C. Influência da gravidez e dos anticoncepcionais na reabsorção radicular e na remodelação óssea, conseqüente à movimentação dentária induzida. Avaliação microscópica. Bauru, 1995. 144p. Dissertação (Mestrado) Faculdade de Odontologia de Bauru, Universidade de São Paulo.

101. PHILLIPS, J. R. Apical root resorption under orthodontic therapy. Angle Orthodont., v.25, n.1, p.1 22, Jan. 1955.

102. PHILLIPS, R. N. Ligas de metais básicos e ligas de ouro trabalhadas mecanicamente. In: Materiais dentários. 8.ed. 1991. Cap.28, p.310 18.

103. PLETS, J. H. et al. Maxillary central incisor root length in orthodontically treated and untreated patients. Angle Orthodont., v.44, n.1, p.43 7, Jan. 1974. 
104. PROFFIT, W. R. et al. The biologic basis of orthodontic therapy. In: Contemporary Orthodontics 2. ed. Saint Louis, Mosby, 1993. Cap. 9, p.266 88.

105. PROFFIT, W. R. et al. Mechanical principles in orthodontic force. In: Contemporary Orthodontics 2. ed. Saint Louis, Mosby, 1993. Cap. 10, p.289 315 .

106. PROFFIT, W. R. et al. Contemporary fixed appliances. In: Contemporary Orthodontics 2. ed. Saint Louis, Mosby, 1993. Cap. 12, p.342 73.

107. PUCHE, L. R. Reabsorcion radicular y ortodoncia. Acta. Odontol. Venez., v.31, n.1, p.44 5, Apr. 1993.

108. QUINTANILLA, D. S. et al. Estudo experimental comparativo de 3 novos bráquetes de baixa fricção. STOMA, v.34, p.41 54, Mar. 1995.

109. REITAN, K. Initial tissue behavior during apical root resorption. Angle Orthodont., v.44, n.1, p.68 82, Jan. 1974.

110. REITAN, K.; RYGH, P. Biomechanical principles and reactions. In: GRABER, T. M.; VANARSDALL JUNIOR, R. L. Orthodontics current principles and techniques. 2.ed. Saint Louis, Mosby, 1994. Cap. 2, p.96 192.

111. REMINGTON, D. N. et al. Long term evaluation of root resorption occurring during orthodontic treatment. Amer. J. Orthodont. Dentofac. Orthop., v.93, n.3, p.186 95, Mar. 1988.

112. RÖNNERMAN, A.; LARSSON, E. Overjet, overbite, intercanine distance and root resorption in orthodontically treated patients. Swed. dent. J., v.5, n.1, p.21 7, 1981.

113. ROSENBERG, M. N. An evaluation of the incidence and amount of apical root resorption and dilaceration occuring in orthodontically treated teeth having incompletly formed roots at the beginning of Begg treatment. Amer. J. Orthodont., v.61, n.5, p.524 5, May 1972. Abstract

114. RUDOLPH, C. E. A comparative study in root resorption in permanent teeth. J. Amer. dent. Ass., v.23, p.822 6, May 1936.

115. RYGH, P. Orthodontic root resorption studied by electron microscopy. Angle Orthodont., v.47, n.1, p.1 16, Jan. 1977.

116. SACHDEVA, R. et al. Ligas ortodônticas correntemente em uso. Revisão (parte II). Rev. Odont. USP, v.4, n.4, p.343 8, out./dez. 1990.

117. SANDESTED, C. apud SCHWARZ, A. M. Tissue changes incidental to orthodontic tooth movement. Int. J. Orthodont., v.18, p.331 52, 1932. 
118. SASAKI, T. et al. Cytodifferentiation of odontoclasts in physiologic root resorption of human decíduos teeth. In: DAVIDOVICH, Z., ed. Biological mechanisms of tooth eruption and root resorption. Ohio, Columbus, 1988. p.321 28.

119. SCARTEZZINI, C. Dicionário odontológico 3 ed. Rio de Janeiro, Científica, 1964. 127 p.

120. SCHWARZ, A. M. Tissue changes incidental to orthodontic tooth movement. Int. J. Orthodont., v.18, p.331 52, 1932.

121. SELAIMEN, C. R. P.; MARTINS, J. C. da R.; MARTINS, L. P. O planejamento mecânico e as novas ligas metálicas ortodônticas. Rev. Ortodont. gaúcha, v.1, n.1, abr. 1997. 6p. Online. Disponível em: http://www.sogaor.org.br/ligasmet.htm. 21 set. 1997.

122. SHARPE, W. et al. Orthodontic relapse, apical root resorption, e crestal alveolar bone levels. Amer. J. Orthodont. Dentofac. Orthop., v.91, n.3, p.252 8, Mar. 1987.

123. SILVA FILHO, O. G. da et al. Estimativa da reabsorção radicular em 50 casos ortodônticos bem finalizados. Ortodontia, v.26, n.1, p. 24 36, jan./abril 1993.

124. SIMAS, L. J. P. Glossário odontológico, São Paulo, Pascast, 1989. 680 p.

125. SPURRIER, S. W. et al. A comparison of apical root resorption during orthodontic treatment in endodontically treated and vital teeth. Amer. J. Orthodont. Dentofac. Orthop., v. 97, n.2, p.130 4, Feb. 1990.

126. STEADMAN, S. R. Résumé of the literature on root resorption. Angle Orthodont., v.12, n.1, p.28 38, Jan. 1942.

127. STEPHENS, C. D.; HOUSTON, W. J. B.; WATERS, N. E. Multiple $\sim$ strand arches. Dent. Pract., v.22, n.4, p.147 9, Dec. 1971.

128. STUTEVILLE, B. S. Injuries caused by orthodontic forces and the ultimate results of these injuries. Amer. J. Orthodont. oral Surg., v.24, n.2, Feb. 1938.

129. SWAIN, B. F. Brackets: Plain, prescribed, preadjusted? Amer. J. Orthodont., v.104, n.3, p.276, Sept. 1993.

130. TAITHONGCHAI, R.; SOOKKORN, K.; KILLIANY, D. M. Facial and dentoalveolar structure and the prediction of apical root shortening. Amer. J. Orthodont. Dentofac. Orthop., v.110, n.3, p.296 302, Sept. 1996.

131. TAVARES, C. A.; SAMPAIO, R. K. L. Reabsorção dantária patológica externa. Rev. Ortodont. gaúcha, v.1, n.1, abril 1997. 28p. Online. Disponível em: http://www.sogaor.org.br/reabsoro.htm. 21 set. 1997. 
132. TAYLOR, T. S.; ACKERMAN, R. J.; HARDMAN, P. K. Exposure reduction and image quality in orthodontic radiology: a review of the literature. Amer. J. Orthodont. Dentofac. Orthop., v. 93, n.1, p.68 77, Jan. 1988.

133. TRONSTAD, L. Root resorption a multidisciplinary problem in dentistry. In: DAVIDOVICH, Z., ed. Biological mechanisms of tooth eruption and root resorption. Ohio, Columbus, 1988., p.293 301.

134. VIAZIS, A. D. Orthodontic Mechanoterapy. Orthodontic wires. In: Atlas of orthodontics. Principles and clinical application. Philadelphia, Saunders, 1993. Cap.6, p.153 165.

135. VIAZIS, A. D. Orthodontic seminar syllabus. Unites States of America, University of South California, Jan. 1995.

136. VIAZIS, A. D. Bioefficient therapy. J. clin. Orthodont., v.29, n.9, p.552 68, Sept. 1995.

137. VONDERAHE, G. Postretention status of maxillary incisors with root end resorption. Angle Orthodont., v.43, n.3, p.247 55, July 1973.

138. WEHRBEIN, H.; FUHRMANN, R.A.W.; DIEDRICH, P. R. Human histologic tissue after long-term orthodontic tooth movement. Amer. J. Orthodont. Dentofac. Orthop., v.107, n.4, p.360 71, Apr. 1995.

139. WESSELIK, P. R.; BEERTSEN, W. Initiating factors in dental root resorption. In: DAVIDOVICH, Z., ed. Biological mechanisms of tooth eruption and root resorption. Ohio, Columbus, 1988. p.329 334.

140. WICKWIRE, N. et al. The effect of tooth movement upon endodontically treated teeth. Angle Orthodont., v.44, n.3, p.235 42, 1974. 
ABSTRACT 
Apical root resorption is an undesirable, but frequent side effect of orthodontic treatment, and therefore improvements in orthodontic materials and techniques are in constant development to decrease it. One of the most recently developed orthodontic techniques is the Bioefficient Therapy, that utilizes the most contemporary orthodontic materials. Therefore, the primary objective of this study was to compare the amount of root resorption after orthodontic treatment between the simplified standard edgewise technique (group 1), the edgewise straight wire system (group 2) and the Bioefficient Therapy (group 3). It was also the purpose of this investigation to compare the treatment time between these techniques, as well as the amount of root resorption in the whole sample studied, and the prevalence of root resorption in the upper and lower incisors. Thus, periapical radiographs using the long cone paralleling technique were obtained for the upper and lower incisors from 30 patients for each group. The mean ages of the patients at the beginning of treatment were 13.92, 14.18 and 14.29 for groups 1, 2, and 3, respectively. Root resorption was ranked by scores, according to the method of LEVANDER; MALMGREN76, by 2 examiners, that presented an excellent intra and interexaminer calibration by Kendall concordance coefficient. Results of the Kruskal Wallis test demonstrated that group 3 (Bioefficient Therapy) presented less root resorption than the others. The Scheffé test demonstrated that treatment time was longer for group 1 (simplified standard edgewise technique) as compared to the others. Considering the whole sample, there was no root resorption in $2.25 \%$ of the analyzed teeth. There was only a slight resorption in $42.56 \%$, a moderate resorption in $53.37 \%$, an accentuated resorption in $1.40 \%$ and an extreme root resorption in only $0.42 \%$ of the teeth. The prevalence of resorption for each incisor indicated, in decreasing order, a larger resorption for the upper centrals, followed by the upper laterals, lower centrals and lastly, the lower lateral incisors. 
APÊNDICE 1 Escores determinados em 10 pacientes selecionados aleatoriamente para o cálculo do erro intra examinador grupo 1

\section{TABELA 1 Grupo 1}

\begin{tabular}{|c|c|c|c|c|c|c|c|c|c|c|c|c|c|c|c|c|}
\hline $\mathrm{N}^{\mathrm{o}}$ & $12 \mathrm{~A}$ & $12 \mathrm{E}$ & $11 \mathrm{~A}$ & $11 \mathrm{E}$ & $21 \mathrm{~A}$ & $21 \mathrm{E}$ & $22 \mathrm{~A}$ & $22 \mathrm{E}$ & $42 \mathrm{~A}$ & $42 \mathrm{E}$ & $41 \mathrm{~A}$ & $41 \mathrm{E}$ & $31 \mathrm{~A}$ & $31 \mathrm{E}$ & $32 \mathrm{~A}$ & $32 \mathrm{E}$ \\
\hline $\mathrm{C} 2$ & 2 & 2 & 1 & 1 & 2 & 1 & 2 & 2 & 1 & 1 & 2 & 2 & 2 & 2 & 1 & 1 \\
\hline $\mathrm{C} 4$ & 1 & 2 & 2 & 2 & 2 & 2 & 2 & 2 & 1 & 1 & 2 & 2 & 2 & 2 & 1 & 1 \\
\hline $\mathrm{C} 7$ & 2 & 2 & 1 & 1 & 2 & 2 & 2 & 2 & 1 & 1 & 1 & 1 & 1 & 1 & 1 & 1 \\
\hline C15 & 2 & 1 & 2 & 2 & 1 & 1 & 2 & 2 & 0 & 0 & 1 & 1 & 1 & 1 & 0 & 0 \\
\hline $\mathrm{C} 20$ & 1 & 1 & 1 & 1 & 1 & 1 & 2 & 2 & 1 & 1 & 1 & 1 & 2 & 2 & 1 & 1 \\
\hline $\mathrm{C} 22$ & 2 & 2 & 1 & 1 & 2 & 2 & 2 & 2 & 1 & 1 & 2 & 2 & 2 & 2 & 1 & 1 \\
\hline $\mathrm{C} 23$ & 1 & 1 & 2 & 2 & 1 & 1 & 2 & 2 & 1 & 1 & 2 & 2 & 1 & 1 & 1 & 1 \\
\hline C25 & $\mathrm{A}$ & $\bar{A}$ & 1 & 1 & 1 & 1 & 1 & 1 & 1 & 1 & 1 & 1 & 1 & 1 & 2 & 2 \\
\hline $\mathrm{C} 26$ & 3 & 3 & 4 & 4 & 2 & 2 & 2 & 2 & 2 & 2 & 2 & 2 & 2 & 2 & 1 & 1 \\
\hline C27 & 1 & 1 & 1 & 1 & 2 & 2 & 1 & 1 & 1 & 1 & 2 & 2 & 2 & 2 & 1 & 1 \\
\hline
\end{tabular}

(A=1a medição; $\mathrm{E}=2 \underline{a}$ medição; 12=incisivo lateral superior direito, 11=incisivo central superior esquerdo, 21=incisivo lateral superior esquerdo, 42=incisivo lateral inferior direito, 41=incisivo central inferior direito, $31=$ incisivo central inferior esquerdo, 32=incisivo lateral inferior esquerdo) 
APÊNDICE 2 Escores determinados em 10 pacientes selecionados aleatoriamente para o cálculo do erro intra examinador grupo 2

TABELA 2 Grupo 2

\begin{tabular}{lllllllllllllllll}
\hline $\mathrm{N}^{\mathrm{o}}$ & $12 \mathrm{~A}$ & $12 \mathrm{E}$ & $11 \mathrm{~A}$ & $11 \mathrm{E}$ & $21 \mathrm{~A}$ & $21 \mathrm{E}$ & $22 \mathrm{~A}$ & $22 \mathrm{E}$ & $42 \mathrm{~A}$ & $42 \mathrm{E}$ & $41 \mathrm{~A}$ & $41 \mathrm{E}$ & $31 \mathrm{~A}$ & $31 \mathrm{E}$ & $32 \mathrm{~A}$ & $32 \mathrm{E}$
\end{tabular}

\begin{tabular}{lllllllllllllllll}
\hline \hline R2 & 2 & 2 & 1 & 1 & 1 & 1 & 1 & 2 & 1 & 1 & 1 & 2 & 1 & 2 & 1 & 1 \\
\hline R3 & 1 & 1 & 2 & 2 & 2 & 1 & 2 & 2 & 2 & 2 & 2 & 2 & 2 & 2 & 2 & 2 \\
\hline R8 & 2 & 2 & 2 & 2 & 2 & 2 & 2 & 2 & 2 & 2 & 2 & 2 & 2 & 2 & 2 & 2 \\
\hline R11 & 1 & 1 & 1 & 1 & 1 & 1 & 1 & 1 & 1 & 2 & 2 & 2 & 2 & 2 & 1 & 1 \\
\hline R15 & 2 & 2 & 2 & 2 & 1 & 1 & 2 & 2 & 1 & 1 & 2 & 2 & 2 & 1 & 1 & 1 \\
\hline R19 & 2 & 2 & 4 & 4 & 3 & 3 & 2 & 2 & 2 & 2 & 2 & 2 & 2 & 2 & 2 & 2 \\
\hline R22 & 2 & 2 & 2 & 2 & 2 & 2 & 2 & 2 & 1 & 1 & 2 & 2 & 2 & 2 & 1 & 1 \\
\hline R24 & 1 & 1 & 1 & 1 & 2 & 2 & 1 & 1 & 1 & 1 & 1 & 1 & 1 & 1 & 2 & 1 \\
\hline R27 & 2 & 2 & 2 & 2 & 2 & 2 & 2 & 2 & 2 & 2 & 1 & 1 & 1 & 1 & 2 & 2 \\
\hline R29 & 1 & 1 & 1 & 1 & 1 & 1 & 2 & 2 & 2 & 2 & 2 & 2 & 2 & 2 & 2 & 2
\end{tabular}

(A=1a medição; $\mathrm{E}=2$ a medição; 12=incisivo lateral superior direito, 11=incisivo central superior esquerdo, 21=incisivo lateral superior esquerdo, 42=incisivo lateral inferior direito, 41=incisivo central inferior direito, 31=incisivo central inferior esquerdo, 32=incisivo lateral inferior esquerdo) 
APÊNDICE 3 Escores determinados em 10 pacientes selecionados aleatoriamente para o cálculo do erro intra examinador grupo 3

TABELA 3 Grupo 3

$\begin{array}{lllllllllllllllll}\mathrm{N}^{\mathrm{o}} & 12 \mathrm{~A} & 12 \mathrm{E} & 11 \mathrm{~A} & 11 \mathrm{E} & 21 \mathrm{~A} & 21 \mathrm{E} & 22 \mathrm{~A} & 22 \mathrm{E} & 42 \mathrm{~A} & 42 \mathrm{E} & 41 \mathrm{~A} & 41 \mathrm{E} & 31 \mathrm{~A} & 31 \mathrm{E} & 32 \mathrm{~A} & 32 \mathrm{E}\end{array}$

\begin{tabular}{lllllllllllllllll}
\hline \hline B3 & 2 & 2 & 1 & 1 & 2 & 2 & 1 & 1 & 1 & 1 & 2 & 2 & 1 & 1 & 1 & 1 \\
\hline B7 & 1 & 1 & 2 & 2 & 1 & 1 & 1 & 1 & 0 & 0 & 1 & 1 & 1 & 1 & 0 & 0 \\
\hline B8 & 2 & 2 & 2 & 2 & 1 & 1 & 2 & 2 & A & A & 1 & 1 & 1 & 1 & 1 & 1 \\
\hline B9 & 1 & 1 & 1 & 1 & 2 & 2 & 2 & 2 & 1 & 1 & 1 & 1 & 2 & 2 & 1 & 2 \\
\hline B10 & 2 & 2 & 3 & 3 & 2 & 2 & 2 & 2 & 1 & 1 & 1 & 1 & 2 & 2 & 1 & 1 \\
\hline B13 & 1 & 1 & 2 & 2 & 2 & 2 & 2 & 2 & 1 & 1 & 2 & 2 & 2 & 2 & 1 & 1 \\
\hline B15 & 1 & 1 & 1 & 1 & 2 & 2 & 1 & 1 & 1 & 1 & 1 & 1 & 0 & 0 & 0 & 0 \\
\hline B16 & 2 & 2 & 2 & 2 & 1 & 1 & 2 & 2 & 1 & 1 & 2 & 2 & 1 & 2 & 1 & 1 \\
\hline B17 & 2 & 2 & 2 & 2 & 2 & 2 & 2 & 2 & 1 & 1 & 1 & 1 & 2 & 2 & 1 & 1 \\
\hline B18 & 1 & 1 & 2 & 2 & 2 & 2 & 1 & 1 & 1 & 1 & 2 & 2 & 1 & 1 & 1 & 1 \\
\hline
\end{tabular}

(A=1a medição; $\mathrm{E}=2 \underline{a}$ medição; 12=incisivo lateral superior direito, 11=incisivo central superior esquerdo, 21=incisivo lateral superior esquerdo, 42=incisivo lateral inferior direito, 41=incisivo central inferior direito, 31=incisivo central inferior esquerdo, 32=incisivo lateral inferior esquerdo) 